\title{
TAXONOMIC VANDALISM IN MALACOLOGY: COMMENTS ON MOLLUSCAN TAXA RECENTLY DESCRIBED BY N. N. THACH AND COLLEAGUES (2014-2019)
}

\author{
BARNA PÁLL-GERGELY ${ }^{1 *}$, ANDRÁs HUNYADI² ${ }^{2}$ KURT AUfFENBERG ${ }^{3}$
}

\author{
${ }^{1}$ Plant Protection Institute, Centre for Agricultural Research, Herman Ottó Street 15, H-1022 Budapest, \\ Hungary (e-mail: pall-gergely.barna@agrar.mta.hu, pallgergely2@gmail.com)

ABSTRACT: A Vietnamese malacologist Nguyen Ngoc Thach described 235 land snail species and subspecies from Southeast Asia with co-authors; further 11 species were described by an Austrian malacologist Franz Huber in Thach's publications (2014-2019). Nearly all taxa were described in self-published books and non-peer-reviewed journals. The low quality of the published photographs, imprecise locality data, deficient literature surveys, and the lack of examination of type specimens raise reasonable doubts concerning the validity of these taxa. In this paper we list all land snails described by Thach and colleagues, and comment on approximately half of his taxa based on examination of the literature and type specimens. As a result, 102 of their taxa are moved to the synonymies of previously described taxa. Three additional taxa, described by other authors, are also considered synonyms of known species here: Helix (Ganesella?) lamyi Dautzenberg et Fischer, 1905, Helix (Plectotropis?) chaudroni Bavay et Dautzenberg, 1909, Amphidromus xiengkhaungensis Inkhavilay et Panha, 2017. Further, nine species are moved to other genera: Pearsonia huberi Thach 2016 to Spiraculum, Streptartemon huberi Thach 2016 to Indoartemon, Tropidophora huberi Thach, 2018 to Leptopoma, Microstele huberi Thach, 2018 to Apoecus, Camaena khamducensis Thach et Huber, 2018 to Hemiplecta, Camaena abbasi Thach, 2016 to Asperitas, Mysticarion huberi Thach, 2016 to Megaustenia, Helixarion annhiae Thach et Huber, 2017 to Megaustenia, and Lamprellia huberi Thach, 2018 to Trichochloritis. Chloritis bifoveata vinhensis Thach et Huber, 2018 is elevated to species level. Oospira naggsi callosa Páll-Gergely, nom. nov. is established as a replacement name for Hemiphaedusa huberi Thach, 2016, non Oospira huberi Thach, 2016. Trichochloritis mussonena Páll-Gergely, nom. nov. is established for Mussonena huberi Thach, 2018, non Trichochloritis huberi (Thach, 2018).

KEY WORDS: new synonyms, new combinations, splitting, poor taxonomy

\section{INTRODUCTION}

The description of Southeast Asian land snails began in the late 18th century when European travellers returned with large and conspicuous specimens. The most active period was the mid-late 19th and early 20th centuries when colonial European naturalists travelled the world to document its biodiversity. Therefore, most specimens examined during the descriptions of these species are housed in European museums. The majority of land snail genera have yet to be properly revised and many species described over a century ago have not yet been illustrated in scientific literature. And, even when illustrated, these early descriptions do not necessarily demonstrate what we now consider as critical morphologi- 
cal characters by which to differentiate species. The description of new Southeast Asian land snail species, as well as their revision, generally requires the examination of all type specimens. This work is often challenging as some museums do not loan type specimens so researchers must visit those collections to properly examine these types.

Vietnamese malacologist NGUYEN NGOC THACH, at times with colleagues, published three non-peer reviewed, self-published books (THACH 2016a, 2017a, 2018a) and several papers (THACH \& HUBER 2014, 2015, 2017, THACH 2015a, b, c, 2016b, c, d, e, f, g, h, 2017b, c, d, e, f, 2018b, c, 2019a, b, c, d, e, f, g, $h$, THACH \& ABBAS 2017a, b). Most taxa in the publications were described solely by Nguyen Ngoc Thach, but occasionally with others, such as the Austrian malacologist, Franz Huber. The lack of peer-review,

\section{MATERIALS AND METHODS}

All scientific names of THACH mentioned in this study are validly introduced according to the ICZN Code, and thus, are available, validly introduced names. The terms "valid species", "valid taxon" and "validity" in the following refers to scientifically acceptable taxa (i.e. not synonyms).

We examined the published photographs of specimens or the actual type specimens described by THACH and his colleagues, and compared them with specimens from other sources and figures published in the literature.

\section{RESULTS}

\section{GENERAL REMARKS}

Altogether THACH and his colleagues (see: Introduction) described 246 land snail species and subspecies from Southeast Asia (Cambodia: 5 taxa, Indonesia: 36 taxa, Laos: 51 taxa, Myanmar: 2 taxa, the Philippines: 1 taxon, Thailand: 11 taxa, Vietnam: 140 taxa). Eleven of these were authored by Franz HUBER ("Huber in Thach") in THACH's books (THACH 2016a, 2017a, 2018a), and one species was described by F. HUBER in a paper authored only by him (HUBER 2015).

Besides these, THACH described a species from Spain (Helicella candoni Thach in THACH 2018a: 72), and one from Madagascar (Kalidos huberi Thach in THACH 2018a: 43), and 88 marine and one freshwater species were described, which are not treated here. Appendix 1 summarises all terrestrial species.

The general shortcomings of these publications are: low quality of the published photographs, imprecise locality data, deficient literature surveys, and the lack of examination or even mention of type specimens of other species that should have been examined, raise reasonable doubts concerning the validity of these taxa. A few species have already been synonymised (PÁLL-GERGELY \& HuNYADI 2018, INKHAVILAY et al. 2019, SUTCHARIT et al. in press).

The high number of new species and subspecies, assigned to 63 genera, makes it impossible to properly deal with them in a single contribution. Most of the groups require extensive systematic revision that may take several years each. Therefore, in this paper we comment only on those taxa that are obvious synonyms, those that have been reviewed earlier, or on those we are currently working.

Abbreviations: CNHM - Chicago Natural History Museum, Chicago, Illinois (= FMNH), HA Collection András Hunyadi (Budapest, Hungary), ICZN - International Commission on Zoological Nomenclature, MNHN - Muséum National d'Histoire Naturelle (Paris, France), NHMUK and NHM The Natural History Museum (London, UK), RMNH National Museum of Natural History Naturalis (Leiden, The Netherlands), SMF - Senckenberg Forschungsinstitut und Naturmuseum (Frankfurt am Main, Germany).

1. In most cases it is obvious that the authors have not examined type specimens of similar species or their illustrations/photographs. Instead, they compared their specimens with images posted on shell dealer websites and other online sources (https:// www.conchology.be/, http://www.bagniliggia.it, Wikipedia, etc.) and popular science books (e.g. AвBOTT's [1989] Compendium of Landshells).

2. Their general understanding of basic intraspecific variability in some genera differs from ours and that of recently active malacologists working in the same geographic areas. As a result, minor differences in shell morphology and colouration observed between individuals are interpreted as characters by which to distinguish species. This has resulted in an unrealistic increase in species numbers, especially in the genus Amphidromus, which often differ in colour and colour pattern even within populations.

3. They have placed new species in genera and families that have not been recorded from Southeast 
Asia, but are known from the Neotropics (Streptartemon Kobelt, 1905, Helminthoglypta Ancey, 1887, Obeliscus Beck, 1837), Australia (Mysticarion Iredale, 1941, Lamprellia Stanisic, 2010, Megalacron I. Rensch, 1934, Mussonena Iredale, 1938), and Madagascar (Tropidophora Troschel, 1847, Cyclotopsis W. T. Blanford, 1864), a clear sign of their lack of knowledge of evolutionary convergence and biogeography. A vast majority of land snail taxa are known to have limited dispersal abilities, and most have clear geographically definable distributions. They are far more likely to be related to taxa that occur in the same geographical area instead of those inhabiting different areas of the world. Furthermore, THACH and his coauthors often place new species in inappropriate families, most conspicuously the Camaenidae versus Ariophantidae/Dyakiidae/ Helicarionidae.

4. Very poor locality data of the new taxa are often provided, making the collection of additional specimens to investigate intraspecific variability unlikely.

5. In many cases these new species belong in genera and families that have never been revised, or not in the past few decades. For example, hundreds of species have been described in the family Camaenidae over the last two centuries. These are often very similar in shell morphology yet no comprehensive revision has been published, even at the genus level. Generic boundaries are not well defined, species' ranges of variation and distributions are largely unknown, and many of the species have never been illustrated. The description of a camaenid species without a comparison of it to pertinent species has a great risk of creating a synonym.

6. The types or illustrated specimens are often immature, juvenile, or so weathered that further taxonomic work on the species will be greatly impeded (see: Appendix 1).

\section{TAXONOMY AND SYSTEMATICS}

\section{Subclass Caenogastropoda}

Superfamily Cyclophoroidea Gray, 1847

Family Alycaeidae W. T. Blanford, 1864

Genus Alycaeus Baird, 1850

Alyccus BAIRD 1850: 27.

Alycaeus somnueki Panha et Patamakanthin, 2001

Fig. 1
7. The ICZN (Art. 72.10) recommends that holotypes be deposited in institutions that can provide proper care to allow examination by others. Despite this recommendation, holotypes of 18 taxa were deposited in private collections. The holotypes of Amphidromus anthonyabbotti, A. lamdongensis, A. montesdeocai, A. noriokowasoei, Pearsonia franzhuberi, P. thachi, P. vilvensi, Pseudobuliminus huberi, Pseudopartula huberi and Pterocyclos schileykoi are deposited in the private collection of F. HUBER, whereas the holotype of A. mariae is in the "Huber Museum", which may mean the same collection. Amphidromus calvinabbasi, Camaena binhgiaensis, C. hoabinhensis, C. lacthuyensis, C. leeana and C. ninhbinhensis are deposited in the THACH's collection, whereas the holotype of Amphidromus thachi krisi is in the private collection of N. KHOA.

8. Providing names to new species is completely at the discretion of the author(s). However, we find it unadvisable to give the same specific epithet to many species, particularly in areas where species boundaries are unclear or unknown. Among the species described by N. N. THACH, 43 are named huberi, 9 as franzhuberi, and 7 as abbasi and F. HUBER named 10 species as thachi (in THACH 2017a, 2018a, and HUBER 2015). These patronyms greatly increase the possibility of secondary homonyms when the generic assignments are changed (e.g. PÁLl-GERGELY \& HUNYADI 2018 and this study). Furthermore, homonyms occur even within the same publication, as well as multiple original spellings (e.g. PÁLL-GERGELY 2019).

The inadequate description of THACH's taxa comes from a general lack of knowledge of the groups and/ or faunas made apparent by: 1) lack of comparison (LC) or mention of previously described species, to which they are similar or identical, and 2) the use of minor shell characters (MC) that are known to be of little or no use by which to distinguish species. These two types are listed in Appendix 1 after each taxon.

Alycaeus somnueki PANHA \& PATAMAKANTHIN 2001: 189-190, plates $1-5$.

Alycaeus huberi ТHACH 2018a: 19, figs 94-95. new synonym

Remarks. In the original description THACH (2018a) stated that A. huberi Thach, 2018 (Fig. 1) differs from A. somnueki Panha et Patamakanthin, 2001 by the ovate, not triangular, aperture, "spire whorls much broader" and dorsal side of body whorl concave (convex in A. somnueki). Firstly, the aperture is "ovate" because the holotype of $A$. huberi is a subadult specimen. 


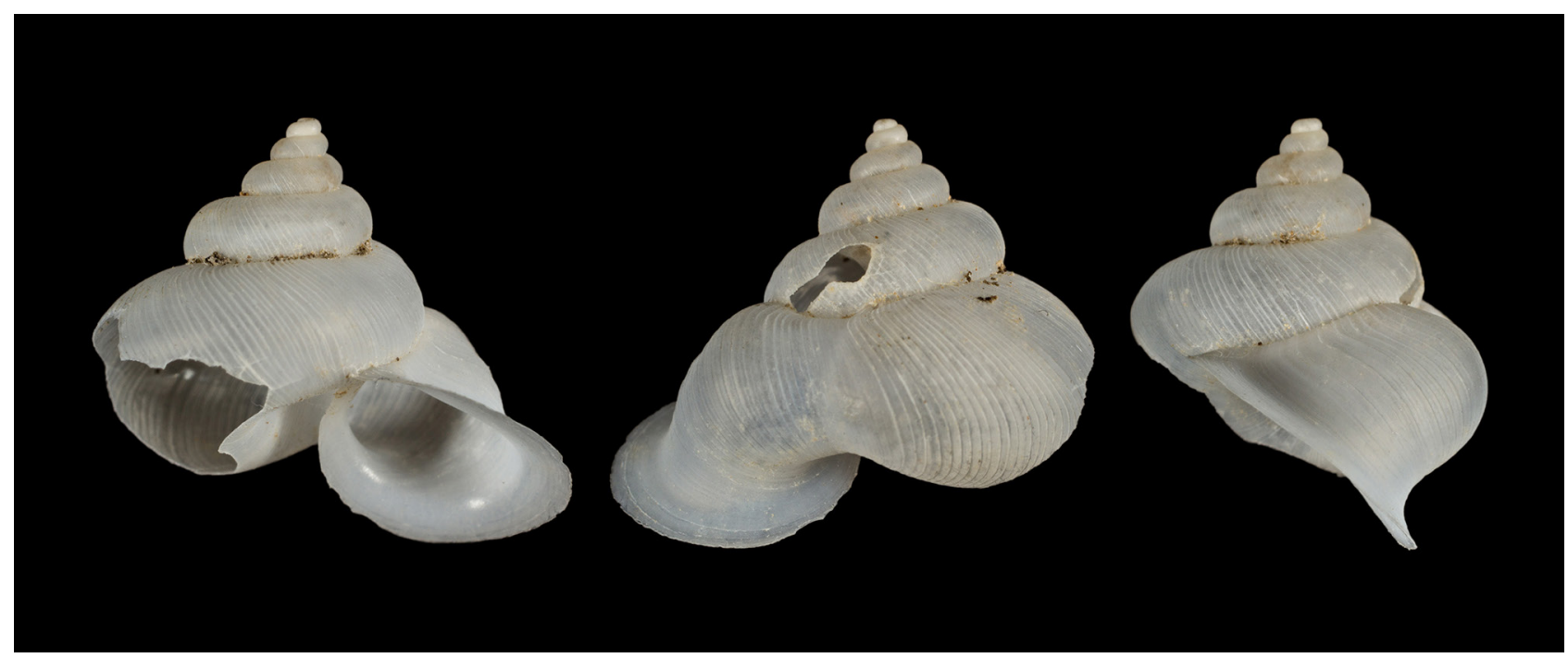

Fig. 1. Holotype of Alycaeus huberi (MNHN-IM-2000-34058). Photo: M. CABALLER

It is clear that the aperture of the holotype of A. huberi is not continuous, as the peristome is not yet developed in the parietal area. In only one alycaeid species (the Japanese Cipangocharax okamurai (Azuma, 1980)) does it appear that the aperture is discontinuous, but even in that case the parietal callus is developed, just thin and blunt, represented as a slight, thin calcareous layer. The aperture is continuous in all other alycaeid species (we have examined most types of all the ca. 380 alycaeid taxa recently). Therefore, the not fully expanded peristome of the subadult holotype of A. huberi causes it to appear different than that of $A$. somnueki. Secondly, we cannot concur that the body whorl of $A$. huberi is broader than that of $A$. somnueki (at least we believe this is what the author meant by "spire whorls"). Thirdly, it is unclear what THACH (2018a) meant by the concave-convex difference of the dorsal body whorl, and we see no difference between the two taxa. Additionally, the type locality of A. huberi "Aouluc, South Thailand" is the same as that of A. somnueki "Ao Luk limestone areas, Krabi Province, (...) Thailand". Therefore, we consider $A$. huberi as a junior synonym of $A$. somnueki.

\section{Family Cyclophoridae Gray, 1847}

\section{Genus Cyclophorus Montfort, 1810}

Cyclophorus MONTFORT 1808-1810, vol. 2 (1810): 290.

Remarks. The genus Cyclophorus Montfort, 1810 contains hundreds of names and it is clear that the infra- and intra-variability of almost all species are very poorly understood. Revision and description of new species of Cyclophorus requires morphometric analysis of large series of specimens and perhaps molecular phylogeny to reveal species boundaries (e.g. NANTARAT et al. 2019). Although the description of new species during the 19th and 20th centuries from a few specimens with imprecise collection data was normal, it is very unwise to do so now. We find it nearly impossible to decide whether the new taxa introduced by THACH and his colleagues are valid and is beyond the scope of this paper. Unfortunately, the thorough paper of NANTARAT et al. (2014) predates the descriptions of new Cyclophorus species presented by THACH.

\section{Genus Cyclotus Guilding in Swainson, 1840}

Cyclostoma (Cyclotus) Guilding in SWAINSON 1840: 186, 336.

\section{Cyclotus huberi Thach, 2018 \\ Fig. 2}

Cyclotus huberi THACH 2018a: 16, figs 63-64.

Remarks. According to the original description $C$. huberi Thach, 2018 is characterised by a "deep groove at periphery". However, it is clear from photos of the holotype that the deep groove is of teratological origin. The specimen had stopped growing about half a whorl behind the peristome, when the snail probably estivated for some time. The groove on the last half whorl was developed probably due to an injured mantle. The groove cannot be ascribed to any breathing functions known in several terrestrial caenogastropod genera (PÁLL-GERGELY et al. 2016), because it would require the presence of a passage between the operculum and the peristome to allow gas exchange.

This species was compared with the Vietnamese C. lubricus (Dautzenberg et Fischer, 1908), which has a short snorkel near its peristome, and C. micron Pilsbry, 1900 (in PILSBRY 1900b). The latter species, now assigned to Nakadaella Ancey, 1904, is ca. $1 \mathrm{~mm}$ in diameter while the holotype of C. huberi is $21.2 \mathrm{~mm}$ in diameter. This species could be valid because the only species known from Laos (C. porrectus Möllendorff, 1898) is clearly not conspecific (see: 


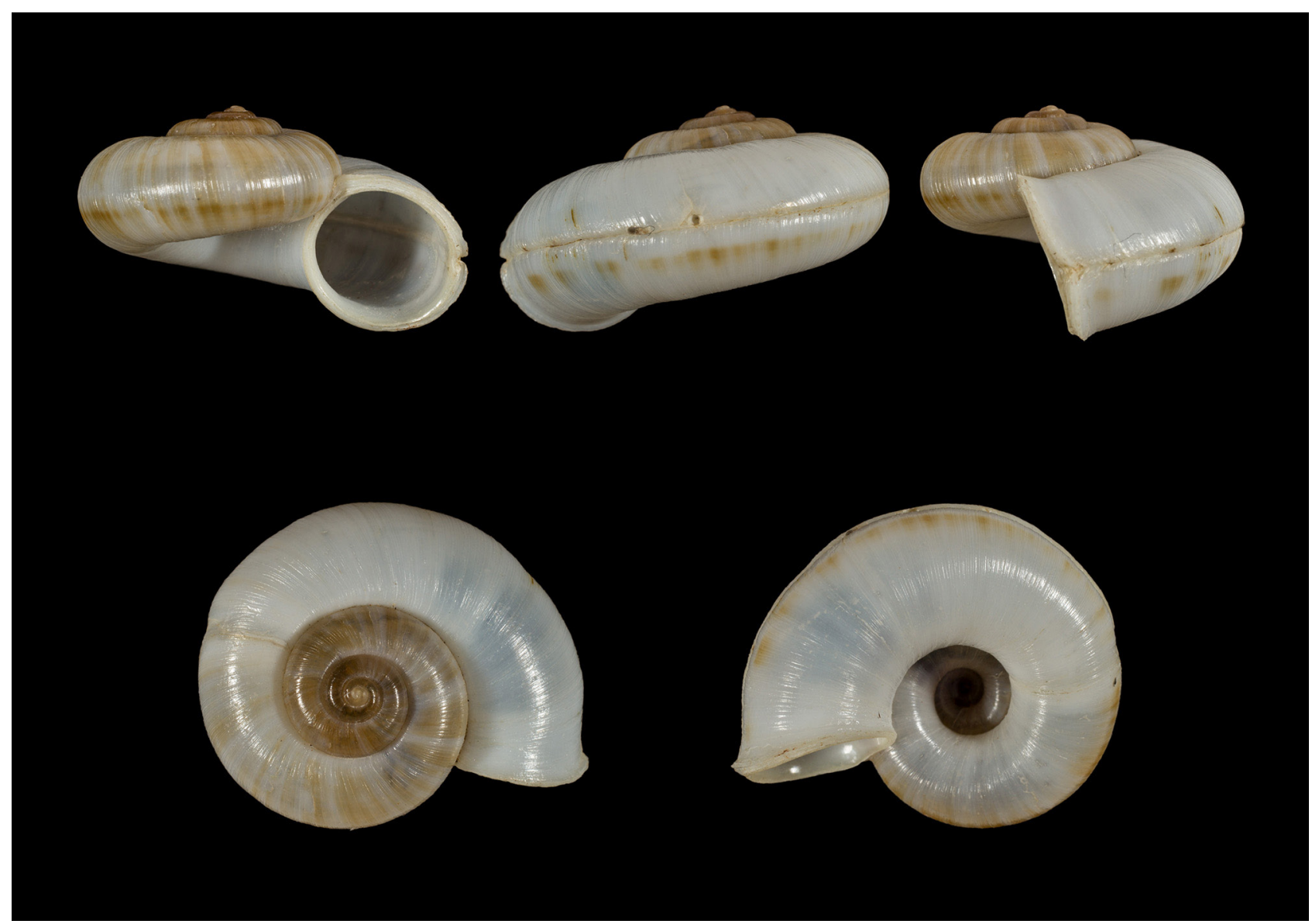

Fig. 2. Holotype of Cyclotus huberi (MNHN-IM-2000-34053). Photo: M. CABALLER

INKHAVILAY et al. 2019). A comprehensive revision of this genus of the neighbouring countries is also necessary.

\section{Cyclotus setosus (Möllendorff, 1894)}

Opisthoporus setosus MÖLLENDORFF 1894: 152, plate 16, figs 14-15.

Cyclotus (Siphonocyclus) setosus - ZILCH 1956: 189, plate 15, fig. 30.

Cyclotus setosus - BENTHEM JUTTING 1960: 11.

Tubicyclotus setosus - HABE 1965: 119, plate 2, figs 8, 9. Cyclotus setosus - MAASSEN 2001: 14.

Cyclotus (Opisthoporus) setosus - EGOROV 2009: 19, fig. $1 \mathrm{G}$.

Spiraculum grohi Thach et Huber in THACH 2018a: 18 new synonym

Spiraculum harryleei Thach et Huber in THACH 2018a: 18 new synonym

Cyclotus harryleei - SUTCHARIT et al. 2019a: 28, fig. 6H.

Remarks. In the original descriptions of Spiraculum grohi Thach et Huber, 2018 and S. harryleei Thach et Huber, 2018 (NHMUK 20180248), they were compared with each other, S. vilvensi Thach et Huber, 2017 (given as "viviensis" in comparison in THACH 2018a), and Pearsonia lamphunensis Tumpeesuwan et Tumpeesuwan, 2015. However, both taxa of Thach et Huber in THACH 2018a are obvious synonyms of
C. setosus (Möllendorff, 1894), a species known from the Samui Islands (MÖLLENDORFF 1894), peninsular Malaysia near Perlis (BENTHEM JuTTING 1960), and Phuket, Thailand (unpublished information). Both $S$. grohi and S. harryleei were described from the nearby Krabi area, Thailand. The differences in shell colour and the slightly differently shaped tube are best explained by intraspecific variation.

\section{Genus Lagocheilus Blanford, 1864}

Lagocheilus BLANFORD 1864: 452.

\section{Lagocheilus klobukowskii (Morlet, 1885)}

Cyclophorus klobukowskii MORLET 1885[1884]: 391, 392, plate 12, fig. 1 .

Cyclotopsis huberi THACH 2018a: 24, figs 178-179. new synonym

Lagocheilus klobukowskii - INKHAVILAY et al. 2019: 19, figs 9B-C, 18C.

Remarks. C. huberi Thach, 2018, described as a member of the family Pomatiidae Newton, 1891, is identical with L. klobukowskii (family Cyclophoridae) based on comparisons with the original figures and those of INKHAVILAY et al. (2019), and therefore considered a junior synonym of the latter here. 


\section{Genus Leptopoma L. Pfeiffer, 1847}

Leptopoma L. PFEIFFER 1847: 47.

Leptopoma huberi (Thach, 2018)

new combination

Tropidophora huberi THACH 2018a: 24.

Remarks. The genus Tropidophora Troschel, 1847 (family Pomatiidae) is distributed in mainland Africa, the small islands of the western Indian Ocean, and has radiated extensively in Madagascar (FISCHER-PIETTE et al. 1993, EMBERTON 1995). Therefore, placing a species collected in Laos in this genus is inappropriate. Furthermore, T. huberi Thach, 2018 differs from Leptopoma annamiticum Möllendorff, 1900 (described in MÖLLENDORFF 1900a), the only Leptopoma species known from Laos (INKHAVILAY et al. 2019), only by the rounded body whorl (keeled in L. annamiticum), but we are reluctant to include this species as a synonym at this time. Instead, this species is herein only transferred to the genus Leptopoma.

\section{Genus Rhiostoma Benson, 1860}

Rhiostoma BENSON 1860: 96.

Rhiostoma herosae Thach et Huber, 2017

Rhiostoma herosae Thach et Huber in THACH 2017a: 17, figs 87-89.

Rhiostoma ninhbinhensis Thach et Huber in THACH 2018a: 17, figs 81a, 82a, 83a, 83b. new synonym

Remarks. The holotypes of the $R$. herosae Thach et Huber, 2017 and $R$. ninhbinhensis Thach et Huber, 2018 are virtually identical in appearance, therefore $R$. ninhbinhensis is considered here a junior synonym of $R$. herosae. Moreover, the type locality of both species is Vietnam, Ninh Bình. The validity of $R$. herosae can be inferred after a revision of Rhiostoma.

Rhiostoma marioni (Ancey, 1898)

Pterocyclos marioni ANCEY 1898: 137, plate 9, fig. f.

Rhiostoma abletti THACH 2016a: 37, figs 53, 122-124. new synonym

Rhiostoma christae THACH 2016a: 38, figs 51, 130-133. new synonym

Rhiostoma marioni - INKHAVILAY et al. 2019: 22, figs $11 \mathrm{~A}-\mathrm{B}, 18 \mathrm{E}$.

Rhiostoma abletti - SUTCHARIT et al. 2019a: 5, fig. 1A Rhiostoma christae - SUTCHARIT et al. 2019a: 17, fig. 3L

Remarks. The holotypes of $R$. abletti Thach, 2016 (NHMUK 20160307) from northwest of Lai Châu city, on the way to Paso, Lai Châu Province, north Vietnam and $R$. christae Thach, 2016 (NHMUK 20160306) from near the road No. 6 to Chieng Ngan, Son La Province, north Vietnam are nearly identical in appearance. The two type localities are situated in neighbouring northern Vietnamese provinces, less than $200 \mathrm{~km}$ apart, not a great distance for molluscs not restricted to limestone habitats. Both taxa are assigned herein as junior synonyms of $R$. marioni (Ancey, 1898), described from neighbouring Laos (Muang Khua Town, Phongsaly Province).

\section{Genus Spiraculum Pearson, 1833}

Spiraculum PEARSON 1833: 590.

\section{Spiraculum huberi (Thach, 2016) \\ new combination}

Pearsonia huberi THACH 2016a: 36, figs 48, 115-118.

Pearsonia franzhuberi THACH 2017a: 15, figs 82-86. new synonym

Pearsonia thachi Huber in THACH 2017a: 16, figs 7881. new synonym

Pearsonia huberi - SUTCHARIT et al. 2019a: 29, fig. 6K.

Remarks. According to the original description of $P$. franzhuberi Thach, 2017, it differs from P. huberi in the "shape of superior margin of aperture and air tube is directed backward". P. thachi Huber, 2017 is said to differ from $P$. franzhuberi by the "shape of operculum with four layers and wing-like structure that is very swollen at dorsal side". Those differences are all best explained by intraspecific variation. Since there are no essential differences between these three taxa, we treat them as a single species, Spiraculum huberi. Additionally, this species in reassigned to Spiraculum Pearson, 1833. KOBELT (1902) fixed Spiraculum hispidum Pearson, 1833 as a type species for both Spiraculum Pearson, 1833 and Pearsonia Kobelt, 1902. Thus, the latter is a junior objective synonym of the former.

\section{Family Pupinidae L. Pfeiffer, 1853}

\section{Genus Pollicaria Gould, 1856}

Pollicaria GOULD 1856: 14.

\section{Pollicaria myersii (Haines, 1855)}

Cyclostoma (Megalomastoma) myersii HAINES 1855: 157, plate 5, figs 9-11.

Pollicaria myersii - KONGIM et al. 2013: 30, figs 2A, $4 \mathrm{~F}-\mathrm{G}, 6 \mathrm{~A}$.

Pollicaria huberi THACH 2018a: 20, figs 116-123. new synonym

Remarks. The shell and aperture shape and shell colour of P. huberi Thach, 2018 agree with that of P. myersii (see: KONGIM et al. 2013), which is also known from Laos. Therefore, the former is considered a junior synonym of the latter.

\section{Pollicaria rochebruni (Mabille, 1887)}

Hybocystis rochebruni MABILLE 1887: 12.

Hybocystis crossei DAUTZENBERG \& D'HAMONVILLE 1887: 220, plate 8, fig. 4 .

Pollicaria rochebruni - KONGIM et al. 2013: 35, figs 5D-E, 6E.

Pollicaria crossei - KONGIM et al. 2013: 37, figs 5F-G, $6 \mathrm{~F}$. 
Pollicaria nicoi THACH 2018a: 21, figs 109-115. new synonym

Ariophanta huberi THACH 2018a: 41, figs 548-549 (PÁll-Gergely \& HunYAdi 2018).

Remarks. A. huberi Thach, 2018 was synonymised with P. rochebruni (Mabille, 1887) in an earlier report (PÁLl-GERGELY \& HuNYADI 2018).

According to the original description, P. nicoi Thach, 2018 differs from $P$. crossei by having "subsutural bands", "short axial ribs below suture", and an operculum with red-brown lines. The meaning of "subsutural bands" is unclear, because the illustrated specimens show no distinct bands below the suture. Short axial ribs below suture are visible on $P$. crossei specimens examined by KongIM et al. (2013). The stripes on the operculum cannot be used to distinguish species, as no evidence is provided on the intra- and interspecific variability of this trait, and the latest revisions (KONGIM et al. 2013, MiNTON et al. 2017) did not use operculum colour as an important trait for species recognition and delimitation. As a consequence, $P$. nicoi is assigned a junior synonym of $P$. crossei, which was synonymised with $P$. rochebruni by MinTON et al. (2017).

\section{Genus Pupinella Baird, 1850}

Pupinella BAIRD 1850: 33.

\section{Pupinella frednaggsi Thach et Huber, 2017}

Pupinella frednaggsi Thach et Huber in THACH 2017a: 19, figs 127, 129-130, INKHAVILAY et al. 2019: 46, figs $16 \mathrm{c}, 18 \mathrm{~h}$.

Type locality. "suburb of Luang Prabang, Central Laos".

Remarks. This is a valid species. We examined a specimen from the following site: Laos, Luang Prabang Province, Ban Pak Ou, Nam Wu (opposite side of Ban Pak Ou), $364 \mathrm{~m}$ a.s.1., $20^{\circ} 03^{\prime} 29.0^{\prime \prime} \mathrm{N}, 102^{\circ} 12^{\prime} 48.0^{\prime \prime} \mathrm{E}$ (site code: 20061113B), leg. K. OHARA 13.11.2006.

\section{Genus Tortulosa Gray, 1847}

Tortulosa GRAY 1847: 177.

\section{Tortulosa tortuosa (Gray, 1825)}

Figs 3-5

\section{Pupa tortuosa GRAY 1825: 413.}

Tortulosa tortuosa - KOBELT 1902: 288.

Perlisia tweediei TOMLIN 1948: 225, plate 11, fig. 6 .

Tortulosa tortuosa - BENTHEM JUTTING 1960: 11.

Tortulosa tortuosa - MAASSEN 2001: 44.

Tortulosa tortuosa - HEMMEN \& HeMmEN 2001: 40, fig. 7.

Tortulosa tortuosa - EGOROV 2013: 14, fig. 23.

Tortulosa tortuosa - RAHEEM et al. 2014: 53.

Tortulosa huberi THACH 2018a: 21, figs 133-138. new synonym
Tortulosa schileykoi Thach et Huber in THACH 2018a: 22 , figs $142-146$. new synonym

Types examined. Kaki Bukit, Perlis, NHMUK 1948.10.2.6 (holotype of Perlisia tweediei, Fig. 3); Thailand: Krabi Province, MNHN-IM-2000-34055 (holotype of Tortulosa schileykoi, Fig. 4); Thailand: Krabi Province, MNHN-IM-2000-34054 (holotype of Tortulosa huberi, Fig. 5).

Remarks. T. huberi Thach, 2018 and T. schileykoi Thach et Huber, 2018 were compared with T. tortuosa and P. tweediei (a synonym of T. tortuosa, see: BENTHEM JUTTING 1960, MAASSEN 2001, EGOROV 2013) in the original description (THACH 2018a). All differences mentioned, such as shell colour and relative length of the free portion of the body whorl are better explained by intraspecific variation. Therefore, T. huberi and T. schileykoi are treated as junior synonyms of $T$. tortuosa.

T. tortuosa is distributed in Krabi Province (HEMmen \& HeMmen 2001), Phuket Island, Thailand (unpublished information) and Kaki Bukit, Malaysia (BENTHEM JUTTING 1960). The type locality, Nicobar Islands, is erroneous (see: BENTHEM JUTTING 1960). The author of the species is BECK (1837) according to CHEMnITZ (1795 see: KobelT 1899-1902), GRAY (1825) [fide RAHEEM et al. (2014)] and MAASSEN (2001). The former is surely not correct, because that name was not made available (BENTHEM JUTTING 1960, RAHEEM et al. 2014). Solving this seemingly complex nomenclatural problem is beyond the scope of the present paper.

\section{Genus Vargapupa Páll-Gergely, 2015}

Vargapupa Páll-Gergely in PÁLL-GERGELY et al. 2015: 42.

\section{Vargapupa oharai Páll-Gergely, 2015}

Vargapupa oharai Páll-Gergely in PÁLL-GERGELY et al. 2015: 42, fig. 8C.

Vargapupa huberi ТHACH 2018a: 22, figs 147-151, 153 (bottom), 154 (right), (PÁlL-GERGELY \& GREGO 2019)

Remarks. V. huberi was synonymised with $V$. oharai Páll-Gergely, 2015 by PÁlL-Gergely \& GREGO (2019).

\section{Superorder Eupulmonata}

\section{Order Stylommatophora}

\section{Suborder Achatinina}

Family Achatinidae Swainson, 1840

Genus Prosopeas Mörch, 1876

Bulimus (Prosopeas) MöRCH 1876: 358. 


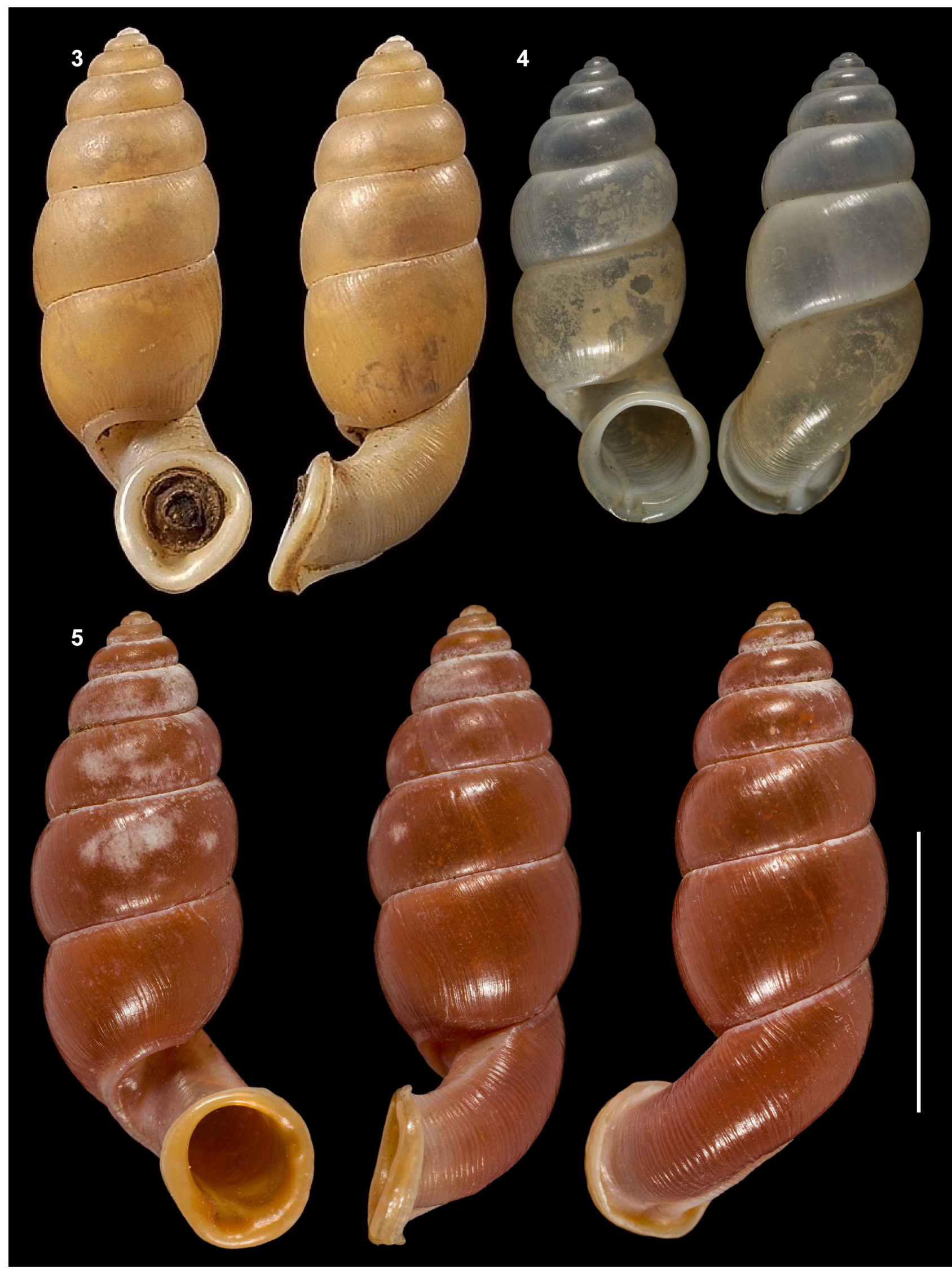

Figs 3-5. Shells of Tortulosa tortuosa (Gray, 1825): 3 - holotype of Perlisia tweediei (NHMUK 1948.10.2.6); 4 - holotype of Tortulosa schileykoi (MNHN-IM-2000-34055); 5 - holotype of Tortulosa huberi (MNHN-IM-2000-34054). Scale bar 10 mm. Photos: H. TAYLOR (3) and M. CABALleR (4-5) 
Remarks. Prosopeas Mörch, 1876 was traditionally classified in the family Subulinidae Fischer et Crosse, 1877 (FISCHER \& CROSSE 1872-1902). However, this family is not recognised by BOUCHET et al. (2017) as a valid taxon (see: explanation therein).

\section{Prosopeas anceyi Pilsbry, 1906}

Figs 6-8

Prosopeas anceyi PILSBRY 1906-1907: 33 (nom. nov. pro Prosopeas macilentum Ancey, 1904 [described in BAVAY \& DAUTZENBERG 1904])

Prosopeas huberi THACH 2018a: 38, figs 497-501. new synonym

Types examined. Bac-Khan, Tonkin, leg. MESSAGER, MNHN-IM-2000-4693 (syntype of Prosopeas macilentum, Fig. 8).

Remarks. We cannot find notable differences between $P$. anceyi and P. huberi Thach, 2018 (Figs 6-7), so the latter is here considered a synonym of the former.

\section{Prosopeas excellens Bavay et Dautzenberg, 1909}

Figs 9-10

Prosopeas excellens BAVAY \& DAUTZENBERG 1909a: 247.
Prosopeas excellens - BAVAY \& DAUTZENBERG 1909b: 282 , plate 10 , figs $11-12$.

Obeliscus owengriffithsi Thach et Huber in THACH 2017a: 30, figs 413-417. new synonym

Types examined. MNHN-IM-2000-33211, holotype of Obeliscus owengriffithsi Thach et Huber, 2017 (Fig. 9); MNHN-IM-2000-4661, syntype of P. excellens (Fig. 10).

Remarks. THATCH \& HUBER (2017) assigned O. owengriffithsi to the Neotropical (see: SCHILEYKO 1999) genus Obeliscus Beck, 1837 (type species: Helix obeliscus Moricand, 1834), and compared it with two other Obeliscus species in the original description. We do not find it likely that this species described from Vietnam could belong to that genus. Furthermore, THATCH \& HUBER (2017) failed to compare O. owengriffithsi to any of the 23 Vietnamese achatinid species (SCHILEYKO 2011, DO \& DO 2014).

The holotype is indistinguishable from $P$. excellens Bavay et Dautzenberg, 1909 in shape (BAVAY \& DAUTZENBERG 1909b, DO \& DO 2014, INKHAVILAY et al. 2019), although larger. In the superfamily Achatinoidea, most species have undetermined growth so overall size and number of whorls are not critical for species discrimination. Therefore, we regard $O$. owengriffithsi as a junior synonym of $P$. excellens.

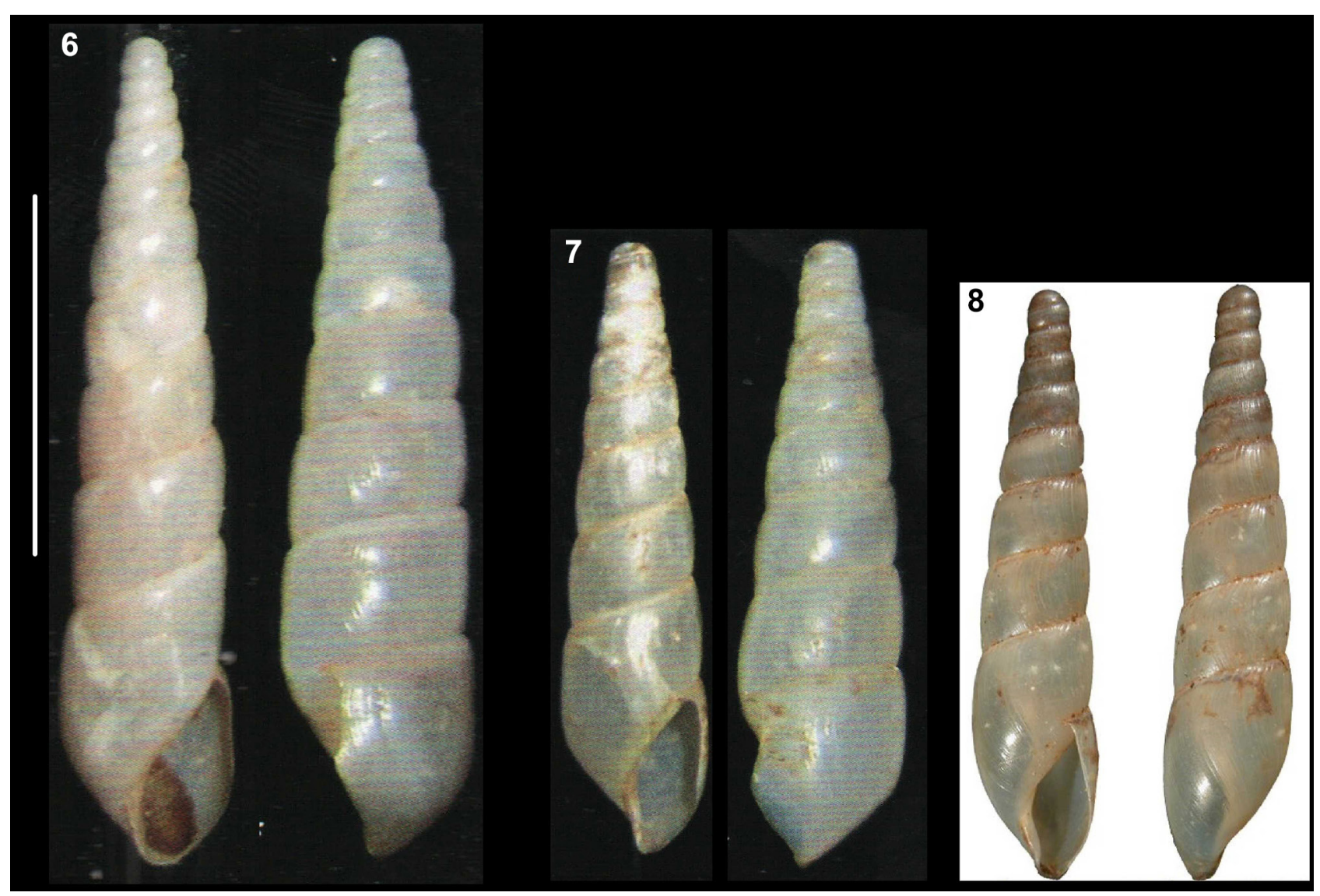

Figs 6-8. Shells of Prosopeas anceyi Pilsbry, 1906: 6 - holotype of Prosopeas huberi Thach, 2018; 7 - paratype of Prosopeas huberi Thach, 2018; 8 - syntype of Prosopeas macilentum Ancey, 1904 (MNHN-IM-2000-4693). Scale bar 10 mm 


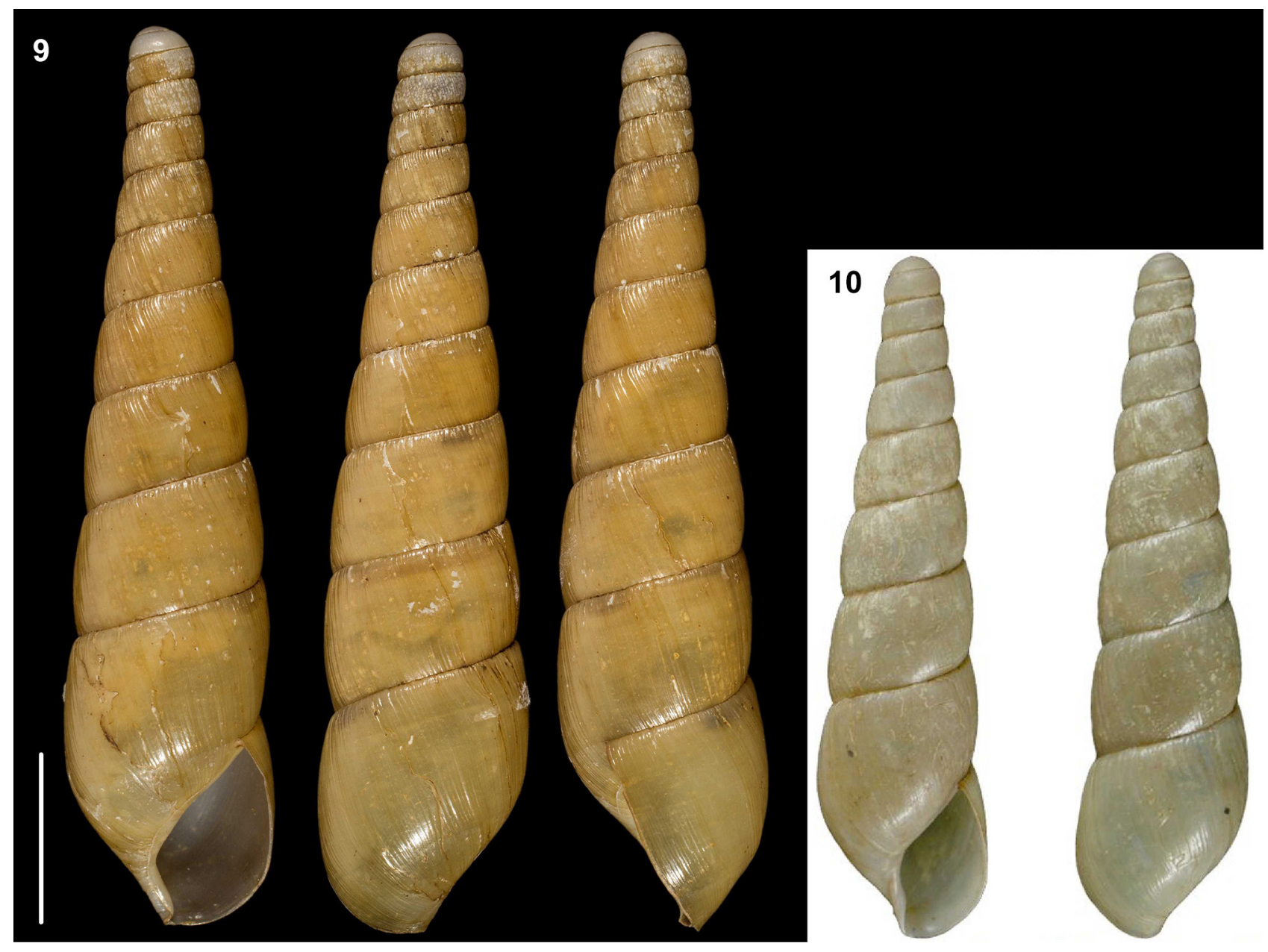

Figs 9-10. Shells of Prosopeas excellens Bavay et Dautzenberg, 1909: 9 - holotype of Obeliscus owengriffithsi Thach et Huber, 2017 (MNHN-IM-2000-33211); 10 - syntype of Prosopeas excellens Bavay et Dautzenberg, 1909 (MNHN-IM-2000-4661). Scale bar $10 \mathrm{~mm}$

\section{Family Streptaxidae Gray, 1860}

\section{Genus Discartemon L. Pfeiffer, 1856}

Streptaxis (Discartemon) L. PFEIFFER 1856: 173.

\section{Discartemon discus (L. Pfeiffer, 1853)}

Streptaxis discus L. PFEIFFER 1853: 252.

Discartemon pallgergelyi THACH 2017a: 31, figs 370373.

Discartemon discus - BUI et al. 2019: 88, figs 1, 2A-B

Discartemon discus - INKHAVILAY et al. 2019: 146, fig. 59A

Discartemon discus - SUTCHARIT et al. (in press) (treats pallgergelyi as a junior synonym)

Remarks. According to the original description, D. pallgergelyi Thach, 2017 differs from D. discus (L. Pfeiffer, 1853) by the presence of a basal lamella. However, a slight thickening of the basal lip is present in the lectotype of $D$. discus (SMF 108534) as well (see: SIRIBOON et al. 2014b, INKHAVILAY et al. 2019). This character is variable and insufficient as a distinguishing character at the species level. Therefore, in agreement with SUTCHARIT et al. (in press), we treat $D$. pallgergelyi as a synonym of $D$. discus.

\section{Discartemon moolenbeeki Maassen, 2016}

Discartemon moolenbeeki MAASSEN 2016: 139, fig. 1.

Discartemon szekeresi Thach et Huber in THACH 2018a: 38, figs 507-510.

Discartemon moolenbeeki - SUTCHARIT et al. (in press) (treats szekeresi as a junior synonym)

Remarks. D. szekeresi Thach et Huber, 2018 is identical with $D$. moolenbeeki Maassen, 2016, therefore, the former is considered a synonym of the latter (see: SUTCHARIT et al. in press). Furthermore, their type localities are within a few kilometres of each other (szekeresi: Ao Luc, between Krabi and Phang Nga, Thailand; moolenbeeki: Krabi Province, Noppharat Thara Beach along the Andaman Sea, Thailand).

\section{Discartemon discamaximus Siriboon et Panha, 2014}

Discartemon discamaximus Siriboon et Panha in SIRIBOON et al. 2014a: 62, figs 5a, b. 
Discartemon huberi THACH 2017a: 30, figs 365-368, 373 (bottom).

Discartemon discamaximus - SUTCHARIT et al. (in press) (treats huberi as a junior synonym).

Remarks. D. huberi Thach, 2017 has been assigned as a junior synonym of $D$. discamaximus (see: SUTCHARIT et al. in press).

\section{Genus Indoartemon Forcart, 1946}

Oophana (Indoartemon) FORCART 1946: 215.

Indoartemon huberi (Thach, 2016)

new combination

Streptartemon huberi THACH 2016a: 60, figs 54, $263-$ 265.

Material examined. 2019/9. Vietnam, Lâm Đồng Prov., Bảo Lộc NNW ca. 17 km, Thác Đạ Mbri (800 $\mathrm{m}), 11^{\circ} 38^{\prime} 30.8^{\prime \prime} \mathrm{N}, 107^{\circ} 44^{\prime} 30.8^{\prime \prime} \mathrm{E}$, leg. HUNYADI \& OTANI, 04.02.2019, coll. HA.

Remarks. Streptartemon Kobelt, 1905 is a neotropical genus, inhabiting much of South America (SCHILEYKO 2000), therefore this species is transferred to the morphologically similar Indoartemon Forcart, 1946 (see: SIRIBOON et al. 2014a, INKHAVILAY et al. 2016).

\section{Genus Oophana Ancey, 1884}

Streptaxis (Oophana) ANCEY 1884: 399.

\section{Oophana bulbulus (Morelet, 1862)}

Ennea bulbulus MORELET 1862: 477.

Oophana bulbulus - SCHILEYKO 2000: 796, fig. 1038.

Indoartemon huberi THACH 2018a: 39, figs 516-520. new synonym

Remarks. The holotype of I. huberi Thach, 2018 is stated to differ from O. bulbulus (Morelet, 1862) by the absence of a blunt basal denticle. However, a slight thickening is visible behind the basal lip, and it would have developed further if the animal lived longer. Due to the identical shell shape we consider I. huberi a junior synonym of $O$. bulbulus.

By transferring S. huberi Thach, 2016 to Indoartemon (see above), I. huberi Thach, 2018 becomes a secondary homonym of I. huberi (Thach, 2016). However, since we consider I. huberi Thach, 2018 a junior synonym of $O$. bulbulus there is no need to provide a replacement name.

\section{Genus Perrottetia Kobelt, 1905}

Odontartemon (Perrottetia) KOBELT 1905 (1905-1906): 108.

\section{Perrottetia thachi Huber, 2018}

Perrottetia thachi Huber in THACH 2018a: 40, figs 528-531.

Remarks. This species is very similar to Oophana pachyglottis (Möllendorff, 1900) (described in MÖLLENDORFF 1900a, see: photo in ZILCH 1961), but we did not compare the two in detail. The validity of $P$. thachi Huber, 2018 needs further revision.

Perrottetia gregoi Thach, 2018

Perrottetia gregoi THACH 2018a: 39, figs 534-536.

Remarks. This species is very similar to Oophana diplodon (Möllendorff, 1900) (described in MÖLLENDORFF 1900a, see: photo in ZILCH 1961), but we did not have the opportunity to compare the two species in detail. Thus, the validity of $P$. gregoi requires further revision.

\section{Suborder Helicina}

\section{Infraorder Pupilloidei}

\section{Family Enidae}

\section{Genus Apoecus Möllendorff, 1902}

Buliminus (Apoecus) Möllendorff in KoBELT 1902 (1899-1902): 887, 1022, 1030.

Apoecus huberi (Thach, 2018)

new combination

Microstele huberi ТHACH 2018a: 37, figs 477-482.

Remarks. Although M. huberi Thach, 2018 is clearly a member of the family Enidae, no revision of Southeast Asian enids has been published making the generic assignment of the species challenging. The genus Microstele consists of small species with apertural denticles, whereas "M. huberi" has no apertural barriers. We provisionally place this species in Apoecus Möllendorff, 1902, which includes species with similar shell morphology (KÖHLER et al. 2016).

\section{Apoecus macrostoma (Bavay et Dautzenberg,} 1912)

Buliminus macrostoma BAVAY \& DAUTZENBERG 1912: 25,26 , plate 4 , figs 11-13.

Mirus huberi THACH 2018a: 37, 485-488. new synonym

Apoecus macrostoma - INKHAVILAY et al. 2019: 58, fig. $25 \mathrm{~F}$.

Remarks. M. huberi Thach, 2018 is identical in shell morphology to A. macrostoma Bavay et Dautzenberg, 1912 , so we have no reservation in treating the former as a synonym of the latter. The type specimen of $A$. macrostoma figured in the original description has fine, vertical, brown stripes on its shell. The shell photographed by INKHAVILAY et al. (2019) also has these stripes, but they are very pale, probably because it is a dead-collected specimen. The holotype of $M$. huberi lacks any radial stripes due to its weathered condition. 


\section{Infraorder Limacoidei}

Family Ariophantidae Godwin-Austen, 1883

Ariophantinae GODWIN-AUSTEN 1883 (1882-1920): 79.

\section{Genus Hemiplecta Albers, 1850}

Hemiplecta ALBERS 1850: 60.

Hemiplecta khamducensis (Thach et Huber, 2018) new combination

Camaena khamducensis Thach et Huber in THACH 2018a: 67, figs 886-888.

Remarks. C. khamducensis Thach et Huber, 2018 is clearly a member of the Ariophantidae, and not a camaenid. Although the assignment of the species to the genus Hemiplecta is provisional, it is very similar in shell morphology to better-known members of Hemiplecta (see: photos of Hemiplecta species in INKHAVILAY et al. 2019). Its validity will be determined upon a systematic revision.

\section{Hemiplecta lanxangnica Inkhavilay et Panha,} 2019

Helminthoglypta huberi THACH 2017a: 54, figs 747-749. Hemiplecta lanxangnica Inkhavilay et Panha in INKHAVILAY et al. 2019 [nomen novum pro Helminthoglypta huberi ТHACH 2017: 54, non Hemiplecta huberi Thach, 2017: 33].

Remarks. INKHAVILAY et al. (2019) transferred H. huberi Thach, 2017 (in THACH 2017a: 54) from Helminthoglypta Ancey, 1887 to the genus Hemiplecta thus creating a secondary homonym of $H$. huberi Thach, 2017 (in THACH 2017a: 33). The replacement name, $H$. lauxangnica Inkhavilay et Panha, 2019 has been proposed.

\section{Hemiplecta pluto (L. Pfeiffer, 1863)}

Helix pluto L. PFEIFFER 1863[1862]: 268.

Hemiplecta huberi THACH 2017a: 33, figs 389-391. new synonym

Hemiplecta pluto - INKHAVILAY et al. 2019: 78, figs 36E-F, 56D

Remarks. In the original description, $H$. huberi Thach, 2017 was compared with photos of a single specimen of $H$. pluto, which were downloaded from a shell dealer's website. However, $H$. pluto is very variable in terms of basic shell morphology (INKHAVILAY et al. 2019), the species inhabits an extensive area in Southeast Asia, and the differences between the two taxa mentioned by THACH (2017a) (weaker keel and stronger sculpture of $H$. huberi) do not seem correct based on the presented photos. Therefore, we assign $H$. huberi as a junior synonym of $H$. pluto.

The use of "Hemiplecta buberi" in the figure captions (THACH 2017a: 97) is an incorrect original spelling.

\section{Genus Kalidos Gude, 1911}

Kalidos GUDE 1911: 273.

Kalidos chastellii (Deshayes in Férussac, 1832) Helix chastellii G. P. Deshayes in D. DE FÉRUSSAC 1832: 106, plate 80, fig. 4 .

Kalidos chastellii - FISCHER-PIETTE et al. 1994: 230, plate 33, figs 10-12.

Kalidos huberi Thach, 2018 in THACH 2018a: 43. new synonym

Remarks. Kalidos huberi Thach, 2018 is a synonym of Kalidos chastellii (Deshayes in Férussac, 1832), which is one of Madagascar's first described snail. It occurs around Tulear/St Augustin which was already a port of call for Europeans since the 1600s. This snail is still abundant there today (OWEN GRIFFITHS pers. comm., December 2019). This taxonomic decision is based on the FisCHER-PIETTE et al. (1994), and not the holotype of Helix chastellii, which seems lost.

\section{Genus Megaustenia Cockerell, 1912}

Megaustenia COCKerell 1912: 70.

\section{Megaustenia huberi (Thach, 2016)}

new combination

Mysticarion huberi THACH 2016a: 61, figs 56, 273-275.

Remarks. Mysticarion Iredale, 1941 is an Australian endemic genus (SCHILEYKO 2002, HYMAN et al. 2017) and its use by ТНАCH (2016a) is puzzling. We transfer this species to the genus Megaustenia, where it most likely belongs based on shell morphology and locality. The validity of the taxon can be determined by systematic revision.

\section{Megaustenia annhiae (Thach et Huber, 2017)} new combination

Helixarion annhiae Thach et Huber in THACH 2017a: 34 , figs 405-407 (erroneous mention as figs 495497: 34).

Remarks. The genus Helicarion (Helixarion is an incorrect original spelling) contains small (at most 22 $\mathrm{mm}$ in diameter) semislugs (SCHILEYKO 2002). We transfer this species to the genus Megaustenia, where it most probably belongs based on shell morphology and locality. The validity of the taxon can be determined by systematic revision.

Family Dyakiidae Gude et Woodward, 1921

Genus Asperitas Gude, 1911

Asperitas GUDE 1911: 273.

Asperitas abbasi (Thach, 2016) new combination

Camaena abbasi THACH 2016d: 109, figs 1-8.

Remarks. The thin peristome and shell colour clearly indicates that C. abbasi Thach, 2016 is not a cama- 
enid, but a dyakiid/ariophantid species. We transfer the taxon herein to Asperitas, a genus widespread in the Indonesian area. Anatomical examination may refine this assignment.

\section{Genus Dyakia Godwin-Austen, 1891 \\ Dyakia GODWIN-AUSTEN 1891: 29.}

\section{Dyakia maarseveeni (Bock, 1881)}

Helix (Nanina) maarseveeni BoCK 1881: 629, plate 55, fig. 2.

Dyakia maarseveeni - LAIDLAW 1963: 142, fig. 14.

Ariophanta abbasi ТHACH 2018a: 41, 543-545. new synonym

Remarks. The holotype of A. abbasi Thach, 2018 (type locality: eastern side of Mount Singgalang, Sumatra) is a juvenile, sinistral shell, which is better assigned to the genus Dyakia Godwin-Austen, 1891. For unknown reasons this species was only compared with A. interrupta (Benson, 1834), originally described from "Sicrigali" (=Sakrigali, northeastern India). BENTHEM JUTTING (1959) lists 10 Dyakia species from Sumatra. The most widespread Sumatran Dyakia species ( $D$. mackensiana (Souleyet, 1841)) has a more elevated spire than that of "A. abbasi" (see: SUTCHARIT et al. 2012). However, D. maarseveeni (Bock, 1881), which was described from practically the same area, largely matches $A$. abbasi. Therefore we consider THACH's (2018a) species as a junior synonym of $D$. maarseveeni.

\section{Family Trochomorphidae Möllendorff, 1890}

\section{Genus Trochomorpha Albers, 1850}

Helix (Trochomorpha) ALBERS 1850: 116.

\section{Trochomorpha benigna (L. Pfeiffer, 1863)}

Helix benigna L. PFEIFFER 1863: 269, plate 36, figs 11, 12. Trochomorpha vinhensis THACH 2018a: 45, figs 598600. new synonym

Trochomorpha benigna - INKHAVILAY et al. 2019: 72, fig. 32F.

Remarks. T. vinhensis Thach, 2018 is identical to $H$. benigna L. Pfeiffer, 1863 in terms of shell shape, colour, and sculpture. Even the type localities (T. vinhensis: Vinh city, Nghệ An Province, northern Vietnam; T. benigna: Lao Mountains, Cambodia = environs of Luang Prabang) are relatively near to each other. Therefore, we assign T. vinhensis Thach, 2018 as a junior synonym of T. benigna (L. Pfeiffer, 1863).

\section{Family Clausiliidae Gray, 1855}

\section{Genus Oospira Blanford, 1872}

Clausilia (Oospira) BLANFORD 1872: 205.

\section{Oospira bolovenica (Möllendorff, 1898)}

Oospira franzhuberi Szekeres et Thach in THACH 2018a: 36, figs 469-470. new synonym
Remarks. O. franzhuberi Szekeres et Thach, 2018 fits within the morphological variability of $O$. boloveni$c a$, and is considered a synonym (M. SZEKERES pers. comm., June 2019).

Oospira naggsi callosa Páll-Gergely, nom. nov. Hemiphaedusa huberi THACH 2016a: 58, figs 59, 295297.

Types examined. Vietnam, Dong Nai Province, eastern part of the Cat Tien National Park near Bau Sau (Crocodile Lake, $\left.11^{\circ} 27^{\prime} 39^{\prime \prime} \mathrm{N}, 107^{\circ} 20^{\prime} 24^{\prime \prime} \mathrm{E}\right), 140 \mathrm{~m}$ a.s.l., leg. Natural History Museum Expedition 14.02.2012 (NHMUK 20140657, holotype of O. naggsi); RMNH 5004199 (holotype of Hemiphaedusa huberi, Fig. 11).

Material examined. 2019/9. Lâm Đồng Province, Bảo Lộc NNW ca. 17 km, Thác Đạ Mbri (800 m), $11^{\circ} 38^{\prime} 30.8^{\prime \prime} \mathrm{N}, 107^{\circ} 44^{\prime} 30.8^{\prime \prime} \mathrm{E}$, leg. HUNYADI \& OTANI, 04.02.2019, coll. HA.

Remarks. "Hemiphaedusa huberi" is very similar to Oospira naggsi Luong et Szekeres, 2014 (described in GREGO et al. 2014), but it is more corpulent than $O$. naggsi, and its plicae are fused to form a lunella-like callus. Based on these minor differences we treat $H$. huberi as a subspecies of $O$. naggsi. Thus, $H$. huberi Thach, 2016 (Fig. 12, THACH 2016a: 58) belongs to the genus Oospira, and becomes a secondary homonym with O. huberi Thach, 2016 (THACH 2016a: 57). Therefore, we propose callosa as a replacement name for $H$. huberi, referring to its lunella-like thickened callus (M. SZEKERES pers. comm., January 2020).

\section{Genus Liparophaedusa Lindholm, 1924}

Phaedusa (Liparophaedusa) LINDHOLM 1924: 62, 71.

\section{Liparophaedusa szekeresi Thach, 2017}

Liparophaedusa szekeresi THACH 2017a: 29, figs 335345.

Remarks. Considered a valid taxon based on examination of type material (M. SZEKERES pers. comm., June 2019).

\section{Genus Grandinenia Minato et Chen, 1984 \\ Grandinenia MINATO \& CHEN 1984: 301.}

\section{Grandinenia rugifera (Möllendorff, 1898)}

Clausilia (Garnieria) rugifera MÖLLENDORFF 1898: 76.

Neniauchenia rugifera - INKHAVILAY et al. 2019: 64, fig. $28 \mathrm{E}$.

Neniauchenia huberi THACH 2016a: 58, figs 57, 299 301. new synonym

Types examined. RMNH 5004200 (holotype of Neniauchenia huberi, Fig. 13).

Remarks. N. huberi Thach, 2016 is a synonym of G. rugifera, which is known from the Boloven plateau, approximately $100 \mathrm{~km}$ west-southwest. This species is easily recognisable based on the wavy neck 


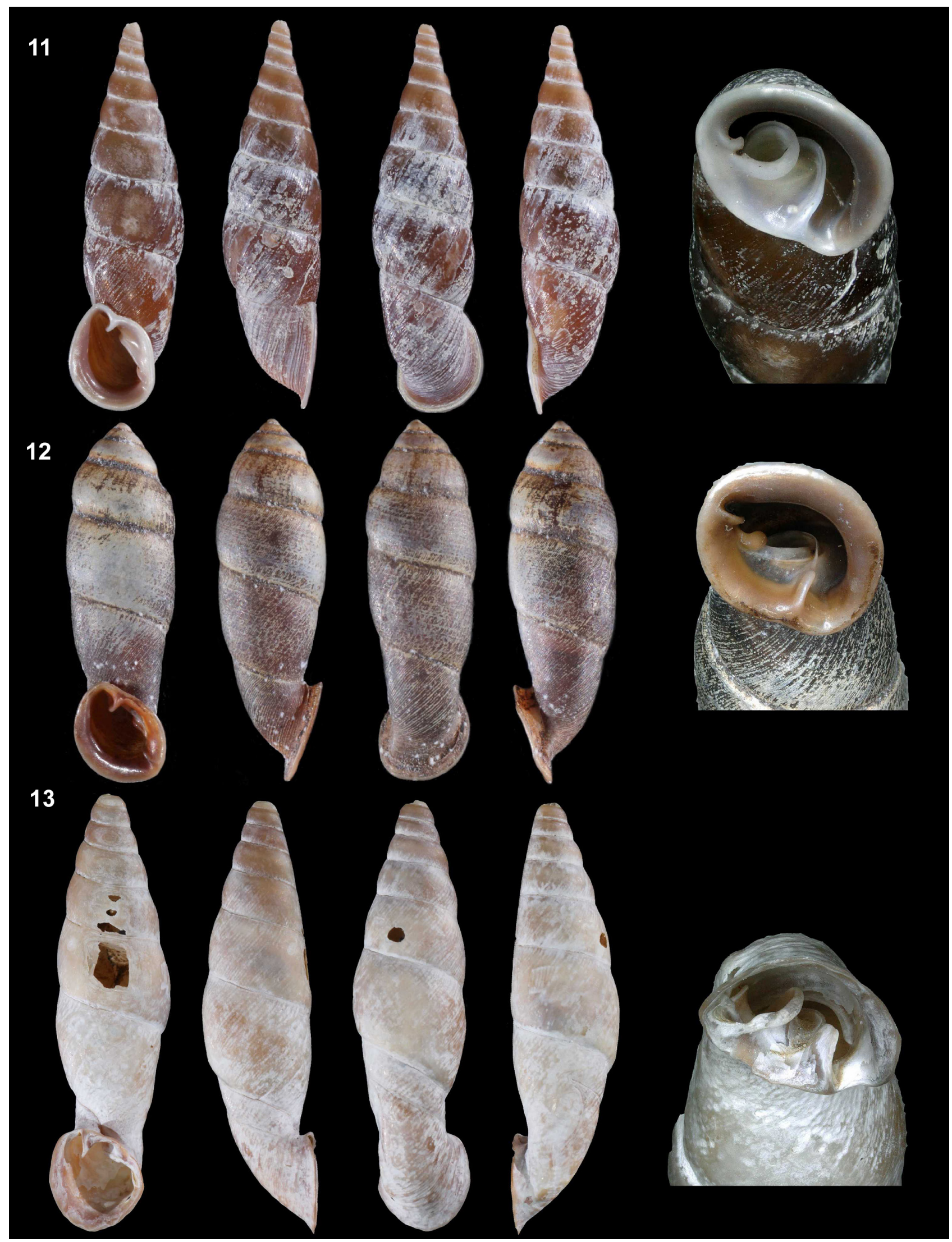

Figs 11-13. Shells of Clausiliidae described by Thach: 11 - Oospira naggsi callosa Páll-Gergely, nom. nov. (holotype of Hemiphaedusa huberi Thach, 2016), H: 29.2 mm; 12 - Castanophaedusa huberi (Szekeres et Thach, 2017) (holotype of Oospira huberi Thach, 2016), H: 19.7 mm; 13 - Grandinenia rugifera (Möllendorff, 1898) (holotype of Neniauchenia huberi Thach, 2016), H: 26.5 mm. All photos: B. PÁlL-GERGELY 
sculpture. The taxon Neniauchena H. Nordsieck, 2002 is now considered a junior synonym of the genus Grandinenia (see: GREGO et al. 2014).

\section{Genus Castanophaedusa Páll-Gergely et Szekeres, 2017}

Castanophaedusa PÁlL-GERGELY \& SZEKERES 2017: 517.

Castanophaedusa huberi (Thach, 2016)

Oospira huberi THACH 2016a: 57, figs 58, 283-286.

Castanophaedusa huberi - PÁLL-GERGELY \& SZEKERES 2017: 517.

Type examined. RMNH 5004194 (holotype of Oospira huberi, Fig. 12).

Remarks. A valid species belonging to the genus Castanophaedusa (see: PÁLL-GERGELY \& SZEKERES 2017).

Genus Messageriella Páll-Gergely et Szekeres, 2017

Messageriella - PÁLL-GERGELY \& SZEKEREs 2017: 518.

Messageriella gregoi (Szekeres et Thach, 2017)

? Oospira gregoi Szekeres et Thach in THACH 2017a: 29, figs 350-354.

Messageriella gregoi - THACH 2018a: 36, fig. 468.

Remarks. A valid species, but, based on the lamella structure and the deeply situated ventral plicae, it is better assigned to the genus Messageriella. The paper of PÁlL-GERGELY \& SZEKERES (2017), in which Messageriella was described, was in press while THACH (2017a) prepared his book. Thus, to avoid nomenclatural problems, this species was tentatively introduced as Oospira.

\section{Infraorder Helicoidei}

\section{Family Camaenidae Pilsbry, 1893}

\section{Genus Amphidromus Albers, 1850}

Bulimus (Amphidromus) AlBers 1850: 138.

Remarks. MOlLuSCABASE (2019) lists 187 species of Amphidromus, 92 species described by THACH and HUBER. Only 95 species have been described by all other authors (MOLLUSCABASE 2019). It is highly unlikely that doubling the number of species in the genus is warranted. Many Amphidromus species have highly variable colour forms, and in some cases, minor aspects of shell morphology are also variable. This has been noted by multiple, competent malacologists over the last two centuries. With the availability of many more specimens due to increased collecting activity over the last few decades, recent studies have clearly demonstrated that this variability exists and many Amphidromus species are some of the most variable of all land snails (SUTCHARIT \& PANHA 2006, INKHAVILAY et al. 2017).
The Amphidromus of West Timor are extremely variable in shell colour and pattern. This variability was extensively studied by HANIEL (1921) and was even mentioned in the original description (SCHEPMAN 1892) of A. reflexilabris. Yet, THACH (2017a, d, e, f, 2018a) and THACH \& ABBAS (2017a, b) described nine new species from the island, all of which we synonymise with $A$. reflexilabris below.

Additionally, SOLEM (1965) studied 500 shells (91 samples), and reported that 9 valid taxa inhabit Thailand. Thach and his colleagues describe three new species from Thailand while only examining 18 specimens (3 samples).

Here we synonymise the Amphidromus species of Thach and co-authors that we believe identical with previously described taxa, or whose shell morphologies and colour patterns fall well within the known variability of those species.

\section{Amphidromus areolatus (L. Pfeiffer, 1861)}

Bulimus areolatus L. Pfeiffer, 1861: 194.

Amphidromus (Syndromus) areolatus - INKHAVILAY et al. 2017: 28, fig. 10C

Amphidromus frednaggsi Thach \& Huber in THACH

2018a: 52, figs 655-660. new synonym

Amphidromus pallgergelyi Thach \& Huber in THACH

2018a: 58, figs 731-737. new synonym

Amphidromus patamakanthini Thach \& Huber in THACH

2018a: 59, figs 779-785. new synonym

Amphidromus gerberi Thach et Huber in THACH 2017a:

39 , figs 649-652, 654-655. new synonym

Remarks. A. (S.) areolatus is distributed in southern Laos (INKHAVILAY et al. 2017) and peninsular and southeast Thailand (SOLEM 1965). The colour pattern of A. patamakanthini Thach et Huber, 2018 is well within the colour variations presented by INKHAVILAY et al. (2017) and we consider it a junior synonym of A. areolatus. A. pallgergelyi Thach et Huber, 2018 has strongly reduced colouration, but agrees in shape and size with $A$. patamakanthini. A. frednaggsi Thach et Huber, 2018, described on the basis of juvenile shells, forms a continuum between the richly ornamented A. patamakanthini and the pale A. pallgergelyi. Therefore, all three species, described from southern Thailand, are considered conspecific and synonyms of the widely distributed $A$. areolatus.

A. gerberi, also described from southern Laos, agrees with $A$. areolatus in the relatively small size, the prominent reddish subsutural band, and fork shape of upper periphery band (clear on penultimate whorl). Thus, that taxon is a junior synonym of $A$. areolatus.

\section{Amphidromus asper Haas, 1934}

Figs 14-16

Amphidromus (Goniodromus) asper HAAS 1934: 96, figs 11-12. 


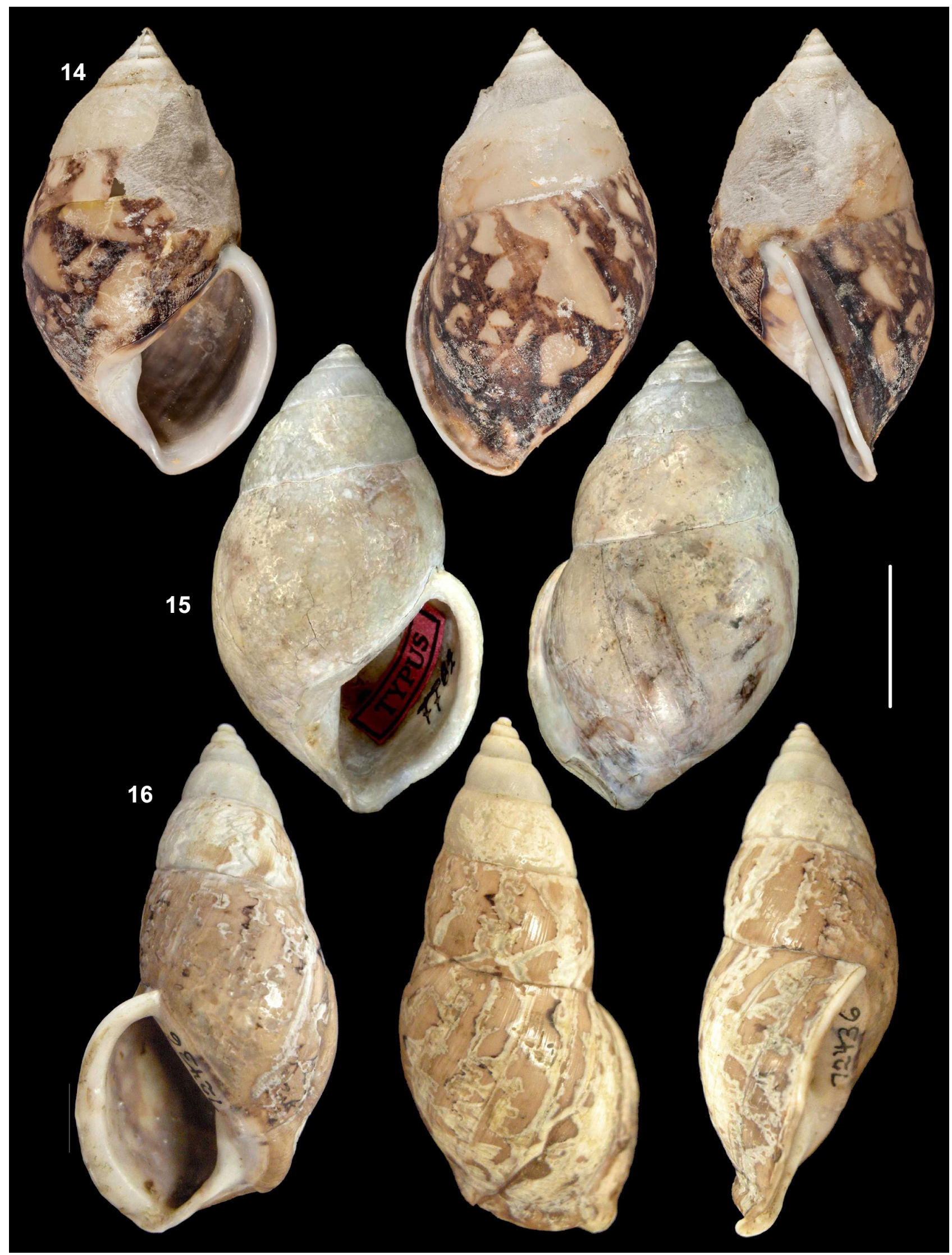

Figs 14-16. Shells of Amphidromus asper Haas, 1934 (14-15) and Amphidromus buelowi Fruhstorfer 1905 (16): 14 - holotype of Amphidromus franzhuberi (MNHN-IM-2000-31892); 15 - holotype of Amphidromus asper (SMF 7762); 16 - paralectotype of Amphidromus buelowi (FMNH 72436). Scale bar $10 \mathrm{~mm}$ 
Amphidromus franzhuberi THACH 2016a: 64, figs 42, 315-319. new synonym

Types examined. Vietnam, Nha Trang, along the border of Nha Trang outskirts and Khanh Vinh District, leg. N. N. THACH, MNHN-IM-2000-31892 (holotype of franzhuberi, Fig. 14); Süd-Annam, 120 km von der Küste, auf dem Wege zum Plateau von Lang-Bian, zw. 600-1,000 m a.s.l., SMF 7762 (holotype of asper Fig. 15); NHMUK 1910.12.30.98 (lectotype of buelowi); "CNHM 72436" = FMNH 72436 (paralectotype of buelowi, Fig. 16).

Remarks. THACH (2016a) compared A. franzhuberi Thach, 2016 only with A. buelowi Fruhstorfer, 1905, which is indeed a different species. However, the holotype of $A$. franzhuberi is identical to that of $A$. as per (although the latter shell is weathered). Therefore, A. franzhuberi is a junior synonym of $A$. asper. THACH (2017a: 37) later stated that $A$. asper (referring to it as "the new species") and $A$. franzhuberi are similar, but noted that the anterior extremity of the aperture is rounded in A. asper and pointed in A. franzhuberi, and that $A$. asper lacks a canal. This is correct for the figured specimen of $A$. asper (THACH 2017a: figs 432-433) (although we find this insufficient to distinguish species), but inaccurate when compared with the holotype of $A$. asper.

\section{Amphidromus baolocensis Thach et Huber, 2016}

Amphidromus baolocensis Thach et Huber in THACH 2016a: 62, figs 34, 302-304.

Amphidromus dambriensis Thach et Huber in THACH 2016a: 63, figs $36,308-310$. new synonym

Amphidromus ngocanhi THACH 2017a: 43, figs 565-569, 572. new synonym

Remarks. Amphidromus baolocensis and A. dambriensis Thach et Huber, 2016 are nearly identical, and are described in the same publication (THACH 2016a). We consider $A$. baolocensis a valid species with page priority in respect to $A$. dambriensis, which we assign as a synonym. A. ngocanhi Thach, 2017 agrees with the other two forms in terms of the slender shell, green colour, and yellow vertical stripes. We herein also consider this taxon a synonym of $A$. baolocensis.

\section{Amphidromus cambojiensis (Reeve, 1860)}

Bulimus cambojiensis REEVE 1860: 204.

Amphidromus cambojiensis - SUTCHARIT et al. 2015: 62, figs $4 \mathrm{~F}-\mathrm{G}$.

Amphidromus lamdongensis Thach et Huber in THACH 2016a: 67, figs 32, 339-342. new synonym

Amphidromus schileykoi THACH 2016a: 68, figs 39, 381-383. new synonym

Amphidromus montesdeocai Thach et Huber in THACH 2017a: 43, figs 454-458. new synonym

Remarks. A. schileykoi Thach, 2016 and A. montesdeocai Thach et Huber, 2017 differ from typical spec- imens of $A$. cambojiensis mostly in shell colouration. Namely, A. montesdeocai is pale with greenish colouration on the body whorl, whereas A. schileykoi possesses a pinkish last whorl, and typical $A$. cambojiensis has faint, brownish radial stripes on the teleoconch. However, the very similar shell and aperture shape, the pink aperture, and the overall simple colour pattern suggest that they all belong to the same species. Therefore, we treat them as junior synonyms of $A$. cambojiensis. A. cambojiensis was originally described from Cambodia, whereas the other two forms are known from neighbouring southern Vietnam. The shell and aperture shape, the colour of the aperture and the shell colouration of $A$. lamdongensis agrees with that of $A$. cambojiensis, therefore we consider that species also as a synonym of $A$. cambojiensis.

\section{Amphidromus comes (L. Pfeiffer, 1861)}

Bulimus comes L. PFEIFFER 1861: 193.

Cochlostyla polymorpha TAPPARONE-CANEFRI 1874: 82, plate 2, figs $4 a-b$.

Amphidromus comes - PILSBRY 1900a: 170, plate 57, figs $1-5$.

Amphidromus comes subsp. polymorphus - PILSBRY 1900a: 171, plate 57, figs 6-10.

Amphidromus hueae Thach et Huber in THACH 2016a: 66 , figs $38,331-334$. new synonym

Amphidromus ngocngai THACH 2017a: 44, figs 446-449. new synonym

Amphidromus vietnamensis Thach et Huber in THACH 2017a: 48, figs 630-635. new synonym

Amphidromus dongnaiensis THACH 2018a: 51, 789-793. new synonym

Amphidromus atricallosus vovanae ТНACH 2019a: 84 new synonym

Remarks. A. hueae Thach et Huber, 2016, A. ngocngai Thach, 2017, A. vietnamensis Thach et Huber, 2017, A. dongnaiensis Thach, 2018, A. atricallosus vovanae Thach, 2019 fit well into the colour variation exhibited by the widespread A. comes polymorphus. However, even that taxon was considered to be a synonym of A. comes ("colour phase") (LAIDLAW \& SOLEM 1961: 651, MAASSEN 2001). Therefore, we treat all mentioned taxa as synonyms of $A$. comes. Further fieldwork and analysis is required.

\section{Amphidromus cruentatus (Morelet, 1875)}

Bulimus cruentatus MORELET 1875: 264, 265, plate 13, fig. 5.

Amphidromus cruentatus - SUTCHARIT et al. 2015: 67, fig. $6 \mathrm{~F}$.

Amphidromus daoae THACH 2016a: 63, figs 29, 384388. new synonym

Amphidromus daoae robertabbasi THACH 2017f: 36, figs 16-18. new synonym

Amphidromus daoae robertabbasi - THACH 2018a: figs 651-652. 
Remarks. The differences between $A$. daoae Thach 2016 and $A$. daoae robertabbasi Thach 2017 are very minor and the two forms are nearly identical. They are similar to the holotype of $A$. cruentatus in their shell shape, reddish brown aperture, and yellow sutural band (SUTCHARIT et al. 2015). We see no reason to maintain $A$. daoae as a separate species, and consider it a synonym of $A$. cruentatus.

\section{Amphidromus eudeli Ancey, 1897}

Amphidromus eudeli ANCEY 1897: 63.

Amphidromus eudeli - INKHAVILAY et al. 2017: fig. 13N. Amphidromus yangbayensis Thach et Huber in THACH 2016a: 70, figs 33, 305-307. new synonym Amphidromus yenlinhae Thach et Huber in THACH 2017a: 49, figs 594-600. new synonym

Remarks. A. yangbayensis Thach et Huber, 2016 is based on a juvenile specimen of $A$. eudeli (see: INKHAVILAY et al. 2017). A. yenlinhae Thach et Huber, 2017 is also similar to the syntype of $A$. eudeli in the brown-yellow radial stripes and the brown-yellow-brown band on the base of the shell. Therefore, both are considered here as synonyms of $A$. eudeli. SCHILEYKO (2011) considers A. eudeli a synonym of Syndromus zebrinus (L. Pfeiffer, 1861), but INKHAVILAY et al. (2017) regards them as separate species, which we follow here.

\section{Amphidromus flavus (L. Pfeiffer, 1861)}

Bulimus flavus L. PFEIFFER 1861: 194.

Amphidromus (Syndromus) flavus - INKHAVILAY et al. 2017: 24, figs 1, 9B, 10E-K, 11C-D, 12A-C.

Amphidromus truongkhoai THACH 2018a: 64, figs 855862. new synonym

Remarks. A. truongkhoai Thach, 2018 is identical with the form of $A$. flavus (var. tryoni Pilsbry, 1900 [in PILSBRY 1900a], see: INKHAVILAY et al. 2017: figs 10I$\mathrm{K})$, therefore we consider it as a synonym of $A$. flavus.

\section{Amphidromus (Syndromus) fuscolabris Möllendorff, 1898}

Amphidromus zebrinus fuscolabris MÖLLENDORFF 1898: 75.

Amphidromus fuscolabris - INKHAVILAY et al. 2017: 32, figs 1, 9E-F, 12G-I, 13J-M, 14C-D.

Amphidromus anhdaoorum THACH 2017a: 36, figs 601608. new synonym

Amphidromus goldbergi Thach et Huber in THACH 2018a: 53, figs 678-683. new synonym

Amphidromus pengzhuoani THACH 2018b: 34, figs 1113. new synonym

Amphidromus stungtrengensis Thach et Huber in THACH 2018a: 63, figs 828-832. new synonym

Amphidromus thakhekensis Thach et Huber in THACH 2017a: 48, figs 553-556 (synonymised with $A$. fuscolabris by INKHAVILAY et al. (2019)).
Remarks. The shell shapes and colour patterns of $A$. anhdaoorum Thach, 2017, A. goldbergi Thach et Huber, 2018, A. pengzhuoani Thach, 2018 and A. stungtrengensis Thach et Huber, 2018 fall well within the known intraspecific variation of typical A. fuscolabris (see: INKHAVILAY et al. 2017: figs 13I-K therein). Therefore, we consider all as synonyms of $A$. fuscolabris. A. thakhekensis Thach et Huber, 2017 is identical to the bandless form of $A$. fuscolabris and is already deemed a synonym (see: INKHAVILAY et al. 2017: fig. 13L).

\section{Amphidromus givenchyi Geret, 1912}

Amphidromus givenchyi GERET 1912: 55, 56, plate 2, figs 21, 22.

Amphidromus givenchyi-LAIDLAW \& SOLEM 1961: 526, 621.

Amphidromus richgoldbergi Thach et Huber in THACH 2017a: 45, figs 505-508.

Amphidromus givenchyi - INKHAVILAY et al. 2019: 90, figs 43D-E (treated $A$. richgoldbergi as a junior synonym of $A$. givenchyi).

Amphidromus severnsi THACH 2017a: 46, figs 585-591. new synonym

Remarks. INKHAVILAY et al. (2019) considered $A$. richgoldbergi simply as a form of $A$. givenchyi. We consider the same is true for $A$. severnsi Thach, 2017 due to the broad shell, green or yellow background colour and lighter subsutural band and regard that taxon as a synonym of $A$. givenchyi. A. givenchyi may be a synonym of $A$. roseolabiatus due to the overall similar shell shape and colouration.

\section{Amphidromus haematostoma Möllendorff, 1898}

Amphidromus haematostoma MÖLLENDORFF 1898: $74-$ 75.

Amphidromus haematostoma - ZILCH 1953: 132, plate 22, figs 4-5.

Amphidromus (Syndromus) haematostoma - INKHAVILAY et al. 2017: 34, figs 1, 130-R.

Amphidromus attapeuensis Thach et Huber in THACH 2017a: 37, figs 573-578.

Amphidromus haematostoma - INKHAVILAY et al. 2019: fig. 44A-C (Amphidromus attapeuensis is considered as a junior synonym)

Remarks. LAIDLAW \& SOLEM (1961) suggested that A. haematostoma was a junior synonym of $A$. roseolabiatus Fulton, 1896, however, based on the type and recently collected material, INKHAVILAY et al. (2017) maintained both species as valid taxa. A. attapeuensis Thach et Huber, 2017 is clearly identical with A. haematostoma, and is regarded as a synonym by INKHAVILAY et al. (2019).

Amphidromus huberi Thach, 2014

Amphidromus huberi THACH 2014: 39, figs 1-8. 
Amphidromus huberi - THACH 2016a: 66, figs 358-361. Amphidromus ledaoae anhi ТНАСН 2018a: 56, figs 845849. new synonym

Amphidromus ledaoae anhi - PÁLL-GERGELY 2019: 75.

Remarks. We consider A. huberi Thach, 2014 a valid species. A. ledaoae anhi Thach, 2018 is nearly identical to $A$. huberi and we herein synonymise the former with $A$. huberi.

\section{Amphidromus ingens Möllendorff, 1900 \\ Amphidromus ingens MÖLLENDORFF 1900b: 23. \\ Amphidromus ingens - ZILCH 1953: 135, plate 23, fig. 25. \\ Amphidromus naggsi THACH \& HUBER 2014: 35, figs 1-13, 15. new synonym}

Remarks. A. naggsi Thach et Huber, 2014 is very similar to the lectotype of $A$. ingens (see: ZILCH 1953). According to the original description of $A$. naggsi, it differs from $A$. ingens by the wrinkled shell surface and the presence of 2-3 broad spiral channels on the body whorl instead of a single spiral channel, the latter being incorrect. However, both possess two elevated spiral ridges on the body whorl, although it is a bit more marked in $A$. naggsi. The difference in the shell surface also does not seem to be supported by the presented photographs. For example, the shell of $A$. naggsi (THACH \& HUBER 2014: fig. 5) appears smoother than the one presented as $A$. ingens (THACH \& HUBER 2014: fig. 14). Since shell sculpture appears to be variable, we consider this character insufficient to differentiate species. Therefore, we allocate $A$. naggsi as a junior synonym of $A$. ingens.

Amphidromus mirandus Bavay et Dautzenberg, 1912

Amphidromus mirandus BAVAY \& DAUTZENBERG 1912: 17-18, plate II, figs 23-24.

Amphidromus heinrichhuberi Thach et Huber in THACH 2016a: 65, figs 30, 321-324. new synonym

Material examined. Lang-Biang, Annam, MNHN IM-2000-2046 (lectotype of mirandus); South Vietnam, Lâm Đồng, Bảo Lộc city, Đoàn Kết commune NHMUK 20160298 (holotype of heinrichhuberi).

Remarks. In the original description A. heinrichhuberi Thach et Huber, 2016 was not compared with any other Amphidromus species. According to the authors, the taxon is unique in terms of its large size, pointed "anterior end of outer lip" and the presence of a "prominent ridge around siphonal fascicole". The shell shape and colour clearly agrees with that of $A$. mirandus Bavay et Dautzenberg, 1912, described from a subadult specimen. The shells of $A$. heinrichhuberi are indeed very large $(58.3-63.5 \mathrm{~mm})$, whereas the lectotype of $A$. mirandus is $48.5 \mathrm{~mm}$. However, this size difference is insufficient for species distinction. Therefore, $A$. heinrichhuberi is a junior synonym of $A$. mirandus.
The type localities of both species are situated within the same province (Lâm Đồng), approximately $110 \mathrm{~km}$ from each other.

Amphidromus mouhoti (L. Pfeiffer, 1861)

Bulimus mouhoti L. PFEIFFER 1861: 194.

Amphidromus setzeri THACH 2015a: 56, figs 1-7. new synonym

Amphidromus renkeri THACH 2018b: 33, plate 1, figs 1-3. new synonym

Amphidromus mouhoti - SUTCHARIT et al. 2015: 82, fig. $11 \mathrm{E}$.

Material examined. 2019/10. Lâm Đồng Province, Bảo Lộc, College of Economics \& Technology, park

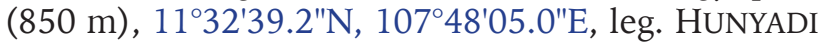
\& OTANI, 04.02.2019, coll. HA.

Remarks. A. setzeri Thach, 2015 and A. renkeri Thach, 2018 agree with $A$. mouhoti (see: SUTCHARIT et al. 2015) in shell shape, the greenish-yellowish, finely striped shell, the slight band below the suture, and the light pinkish columella. Therefore the two former species are here considered as synonyms of $A$. mouhoti. All species are known from southern Vietnam.

\section{Amphidromus palaceus (Mousson, 1849)}

Bulimus palaceus - MOUSSON 1849a: 266 (nomen nudum)

Bulimus palaceus MOUSSON 1849b: 28, 108, plate 3, fig. 1 .

Amphidromus palaceus - LAIDLAW \& SOLEM 1961: 557, fig. 22.

Amphidromus andytani Thach et Abbas in THACH 2017a: 36, figs 460-461, 463-467. new synonym

Remarks. The large, thick walled, yellow shell is characteristic of $A$. palaceus, which is also known from Java, so we consider $A$. andytani Thach et Abbas, 2017 a junior synonym.

\section{Amphidromus (Syndromus) reflexilabris Schepman, 1892}

Amphidromus reflexilabris SCHEPMAN 1892: 152-153.

Amphidromus (Syndromus) reflexilabris - LAIDLAW \& SOLEM 1961: 570, 653, fig. 26.

Amphidromus beschaueri THACH 2018a: 47, figs 622627. new synonym

Amphidromus calvinabbasi THACH 2017d: 41, figs 1-8. new synonym

Amphidromus (Amphidromus) chrisabbasi THACH 2017e: 206, figs 1-8. new synonym

Amphidromus juniorabbasi THACH 2018a: 55, figs 699704. new synonym

Amphidromus lucsegersi THACH \& ABBAS 2017a: 28, figs 1-10. new synonym

Amphidromus marieabbasae THACH 2017a: 42, figs 435-441. new synonym

Amphidromus pamabbasae ТНACH 2017f: 34, figs 1-4. new synonym 
Amphidromus petuchi THACH 2018a: 60, figs 759-765. new synonym

Amphidromus stevehubrechti THACH \& ABBAS 2017b: 119 , figs $1-10$. new synonym

Remarks. SCHEPMAN (1892) mentioned in the original description of $A$. reflexilabris, that "this species varies very much in size and colour, no two specimens being alike...". HANIEL (1921) extensively studied the radula, genital and shell variability of Amphidromus from West Timor. Apparently the Amphidromus taxa of West Timor are among the most variable of land snails in terms of shell morphology and colour. The synonymised nine Amphidromus taxa described by Thach and by Thach \& Abbas can be easily placed in the morphological continuum presented by HANIEL (1921) as follows: A. beschaueri Thach, 2018 (HANIEL 1921: fig. 17), A. calvinabbasi Thach, 2017 (HANIEL 1921: table 1, figs 1-4 in the lower row), A. chrisabbasi Thach, 2017 (HANIEL 1921: plate 2, figs 15-16), A. juniorabbasi Thach, 2018 (HANIEL 1921: plate 1, figs 3-4 in the upper row), $A$. lucsegersi Thach et Abbas, 2017 (HANIEL 1921: plate 2, figs 22-28), A. marieabbasae Thach, 2017 (HANIEL 1921: plate 3, figs $1-7$, plate 5 , figs 10-13), A. pamabbasae Thach, 2017 (HANIEL 1921: plate 1, figs 1-4 in the lower row), A. petuchi Thach, 2018 (HANIEL 1921: plate 1, figs 1-4 in the lower row), A. stevehubrechti Thach et Abbas, 2017 (HANIEL 1921: plate 1, fig. 26, plate 2, figs 22-28). Consequently, we consider all of these taxa are colour forms (synonyms) of $A$. (S.) reflexilabris.

\section{Amphidromus (Syndromus) rhodostylus Möllendorff 1901}

Amphidromus rhodostylus MÖLLENDORFF 1901: 47, 48 (with the following colour variations: var. simplex, roseolineata, nigrolineata, ignea, rhabdota, bipartita, subconfluens)

Amphidromus rhodostylus - ZILCH 1953: 133, plate 22, figs 12-18.

Amphidromus rhodostylus - SCHILEYKO 2011: 51.

Amphidromus abbotthuberorum THACH 2017a: 35, 638639, 641-646. new synonym

Amphidromus anthonyabbotti Thach et Huber in THACH 2017a: 37, figs 625-629. new synonym

Amphidromus baoi ТНACH 2017a: 38, figs 470-474. new synonym

Amphidromus hongdaoae THACH 2017a: 40, figs 673678. new synonym

Remarks. The four species mentioned here (A. $a b$ botthuberorum Thach, 2017, A. anthonyabbotti Thach et Huber, 2017, A. baoi Thach, 2017 and A. hongdaoae Thach, 2017) fit into the morphological continuum known in A. rhodostylus (see: ZILCH 1953). Therefore, we consider them synonyms of that species.

\section{Amphidromus roseolabiatus Fulton, 1896}

Amphidromus roseolabiatus FULTON 1896: 89, plate 6, fig. 8.

Amphidromus roseolabiatus - SUTCHARIT et al. 2015: 86, figs 13J-K.

Amphidromus phuonglinhae THACH 2017a: 45, figs 581584.

Amphidromus koonpoi Thach et Huber in THACH 2018a: 56, figs 766-772. new synonym

Amphidromus phuonglinhae vinhensis Thach et Huber in THACH 2018a: 60, figs 812-815. new synonym

Amphidromus severnsi anhi THACH 2018a: 62, figs 816823.

Amphidromus arlingi ТHACH 2017f: 34, figs 11-13. new synonym

Amphidromus arlingi daklakensis THACH 2017f: 36, figs 6-8. new synonym

Amphidromus johnabbasi THACH 2017b: 35, figs 1-4. new synonym

Amphidromus roseolabiatus - INKHAVILAY et al. 2019: 94, figs 45D-F, 58A. (considered Amphidromus phuonglinhae as a junior synonym)

Amphidromus severnsi improvidus PÁlL-GERGELY 2019: 75 (nom. nov. pro Amphidromus severnsi anhi Thach, 2018) new synonym

Remarks. A. phuonglinhae Thach, 2017, A. phuonglinhae vinhensis Thach et Huber, 2018, A. severnsi improvidus Páll-Gergely, 2019 [replacement name for A. severnsi anhi Thach, 2018], A. arlingi Thach, 2017, A. arlingi daklakensis Thach, 2017, and A. johnabbasi Thach, 2017 fall well within the morphological variability of A. roseolabiatus (see: SUTCHARIT et al. 2015). The corpulent shell, white and/or reddish line along the suture, and the yellow-greenish stipes are characteristic of $A$. roseolabiatus, and therefore, we treat them as synonyms of that species.

A. koonpoi Thach et Huber, 2018 (see: note on multiple original spellings in PÁLL-GERGELY 2019) is slightly more slender than typical A. roseolabiatus, which is not sufficient for species-level distinction from $A$. roseolabiatus, which is a common species in central Laos, near Takhek (INKHAVILAY et al. 2019). The lighter colour of $A$. koonpoi is a result of weathered condition. Thus, A. koonpoi is considered here to be a junior synonym of $A$. roseolabiatus.

Amphidromus schomburgki (L. Pfeiffer, 1860)

Bulimus schomburgki L. PFEIFFER 1860: 137, plate 51, fig. 9.

Amphidromus schomburgki - SUTCHARIT \& PANHA 2006: 23, figs 2, 4J-L, 16A-C, 17A-E.

Amphidromus friedae Thach et Huber in THACH 2016a: 65 , figs $41,350-354$. new synonym

Remarks. The holotype of $A$. friedae is a bleached shell of $A$. schomburgki, which is characterised by the pinkish or purplish ground colour and dark pur- 
ple lip. A. schomburgki is known from Ko Kut island (Thailand) (SUTCHARIT \& PANHA 2006), close to the type locality (Phú Quốc Island in Vietnam) of $A$. friedae. Therefore, we treat that species as a junior synonym of $A$. schomburgki.

\section{Amphidromus smithii Fulton, 1896}

Amphidromus smithii FULTON 1896: 88, 89, plate 7, figs 12, 12a.

Amphidromus smithii - SUTCHARIT et al. 2015: 91, figs 14I-J.

Amphidromus tedbaeri THACH 2017b: 37, figs 18-20. new synonym

Amphidromus baerorum THACH 2017c: 297, figs 6-9. new synonym

Amphidromus christabaerae THACH 2017c: 296, figs 1-4. new synonym

Amphidromus noriokowasoei THACH \& HUBER 2017: 123, figs 1-8. new synonym

Amphidromus eboricolor THACH 2018a: 51, figs 795798. new synonym

Amphidromus davidmonsecouri THACH 2018a: 50, figs 803-807. new synonym

Amphidromus gittenbergeri Thach et Huber in THACH 2018a: 53, figs 670-675. new synonym

Amphidromus noriokowasoei - THACH 2018a: figs 810811.

Amphidromus semicinereus THACH 2018a: 62, figs 603606. new synonym

Amphidromus steveni THACH 2017b: 36, figs 11-14. new synonym

Remarks. A. eboricolor Thach, 2018 and A. gittenbergeri Thach et Huber, 2018 are virtually identical to each other and the paralectotype of $A$. smithii (see: SUTCHARIT et al. 2015: fig. 14J, NHMUK 1896.6.13.38) and we allocate them as synonyms of A. smithii. A. baerorum Thach, 2017, A. christabaerae Thach, 2017, A. davidmonsecouri Thach, 2018, A. noriokowasoei Thach et Huber, 2017, A. semicinereus Thach, 2018, A. tedbaeri Thach, 2017 and A. steveni Thach, 2017 are best interpreted as colour variants of A. smithii and are assigned as synonyms.

\section{Amphidromus suspectus var. albolabiatus Fulton, 1896}

Amphidromus suspectus var. albolabiatus FULTON 1896: 79, plate 6, fig. 9.

Amphidromus chrisabbasi roberti THACH 2018a: 49, figs 638-644. new synonym

Remarks. A. chrisabbasi roberti Thach, 2018 is identical to A. (Syndromus) suspectus var. albolabiata Fulton, 1896 (see: SUTCHARIT et al. 2015: fig. 3D) and we designate it a synonym.

\section{Amphidromus thanhhoaensis Thach et Huber, 2016}

Amphidromus thanhhoaensis Thach et Huber in THACH 2016: 69, figs 35, 325-328.

Amphidromus (Syndromus) xiengkhaungensis Inkhavilay et Panha in INKHAVILAY et al. 2017: 35, figs 1, 13S-T. new synonym

Remarks. A. thanhhoaensis appears to be a valid species and has priority over $A$. xiengkhaungensis Inkhavilay et Panha, 2017 which is relegated as a synonym.

\section{Amphidromus ventrosulus Möllendorff, 1900}

Amphidromus smithi subsp. ventrosulus MÖLLENDORFF 1900a: 133.

Amphidromus smithi ventrosulus - ZILCH 1953: 133, plate 23, fig. 19.

Amphidromus ventrosulus - LAIDLAW \& SOLEM 1961: 668.

Amphidromus ventrosulus - SCHILEYKO 2011: 51.

Amphidromus cargilei Thach et Huber in THACH 2018a: 48, figs 630-634. new synonym

Amphidromus fraussenae Thach et Huber in THACH 2017a: 38, figs 525-530. new synonym

Amphidromus hassi Thach et Huber in THACH 2018a: 54, figs 687-693. new synonym

Amphidromus hassi ngoanmucensis Thach et Huber in THACH 2018a: 54, figs 749-755. new synonym

Amphidromus salzmanni Thach et Huber in THACH 2017a: 45, figs 537-542. new synonym

Remarks. These taxa (A. cargilei Thach et Huber, 2018, A. fraussenae Thach et Huber, 2017, A. hassi Thach et Huber, 2018, A. hassi ngoanmucensis Thach et Huber, 2018, A. salzmanni Thach et Huber, 2017), all described from central and southern Vietnam, agree with each other with respect to shell shape and the uniformly coloured shell (or the apical whorls have a slightly different colour than the body whorl) with a slender sutural band, and some darker colouration on the callus and/or on the peristome and should be classified within the same species. They also largely match $A$. ventrosulus, and are therefore handled as synonyms here. Moreover, A. hassi ngoanmucensis nearly matches the paralectotype of $A$. ventrosulus in all important characters (see: SUTCHARIT et al. 2015).

\section{Genus Camaena Albers, 1850}

Helix (Camaena) AlBERs 1850: 85.

Camaena choboensis (Mabille, 1889)

Helix choboensis MABILLE 1889: 7.

Camaena choboensis - SCHILEYKO 2011: 41 (see: other synonyms of this species there).

Camaena diepae THACH 2017a: 50, figs 717-720. new synonym 
Types examined. Tonkin, MNHN-IM-2000-1908 (2 syntypes of choboensis).

Remarks. C. diepae Thach, 2017 is identical to H. choboensis, therefore, we assign it as a junior synonym.

\section{Camaena duporti (Bavay et Dautzenberg, 1909)}

Helix (Camaena) duporti BAVAY \& DAUTZENBERG 1909a: 234.

Camaena duporti - SCHILEYKO 2011: 42.

Camaena lacthuyensis THACH 2016a: 71, figs 47, 399. new synonym

Types examined. Phu-Ly, coll. Demange, MNHNIM-2000-2033 (syntype of duporti); Phu-Ly, coll. Demange, MNHN-IM-2000-2065 (syntype of duporti var. palidior).

Remarks. C. lacthuyensis Thach, 2016 agrees with C. duporti in shell shape and size, and although the latter has several brownish spiral bands, both agree in the presence of a white band just below the middle line of the body whorl. We interpret the slight colour pattern differences as intraspecific variability, and handle $C$. lacthuyensis as a junior synonym of $C$. duporti.

\section{Camaena gabriellae (Dautzenberg et d'Hamonville, 1887) \\ Helix gabriellae DAUTZENBERG \& D'HAMONVILLE 1887: 216, plate 8, fig. 2. \\ Camaena gabriellae - SCHILEYKO 2011: 42. \\ Camaena binhgiaensis THACH 2016a: 70, figs 46, 397- 401. new synonym \\ Camaena anhi THACH 2017a: 49, figs 713-715. new synonym}

Types examined. Tonkin, Than-Moi, MNHNIM-2000-1896 (syntype of gabriellae).

Remarks. C. anhi Thach, 2017 is identical to C. gabriellae, therefore we designate it a junior synonym of the latter. Camaena binhgiaensis Thach, 2016 differs from typical C. gabriellae only by the more strongly pronounced reddish spiral bands, which we believe to be insufficient for species-level distinction. Therefore, it is also regarded as a junior synonym of C. gabriellae.

\section{Camaena longsonensis (Morlet, 1891)}

Helix longsonensis MORLET 1891: 26.

Camaena longsonensis - SCHILEYKO 2011: 43.

Camaena leeana THACH 2017a: 52, figs 693-696. new synonym

Types examined: MNHN-IM-2000-1928 (syntype of longsonensis).

Remarks. C. leeana Thach, 2017 was compared with C. longsonensis, although all discussed differences (shell size, strength of keel, and height of umbilical area) appear to represent intraspecific variability so we allocate $C$. leeana as a junior synonym of $C$. longsonensis.

Camaena marmorivaga (Mabille, 1889)

Helix marmorivaga MABILLE 1889: 8.

Camaena duyconi Thach et Huber in THACH 2017a: 51, figs 701-702. new synonym

Types examined. Tonkin, leg. BALANSA 1889, MNHN-IM-2000-1936 (syntype of marmorivaga).

Remarks. C. duyconi Thach et Huber, 2017 is identical with $H$. marmorivaga, therefore we designate the former as a junior synonym of the latter.

\section{Camaena pachychila Pilsbry, 1893}

Camaena pachychila PILSBRY 1893 (1893-1895): 265, plate 52 , figs $50-52$.

Camaena suprafusca MöLLENDORFF 1898: 71. new synonym

Camaena (Camaena) suprafusca - ZILCH 1964: 245, plate 6 , fig. 4 .

Camaena franzhuberi THACH 2018a: 66, figs 873-876. new synonym

Camaena franzhuberi laosianus THACH 2018a: 66, figs 878-881. new synonym

Camaena (Camaena) suprafusca - INKHAVILAY et al. 2019: 97, figs 47E, 58C.

Types examined. Annam, NHMUK 1893.2.26.2.3 (holotype + paratype of pachychilus).

Additional material examined. 2019/15. Khánh Hòa Province, Khánh Vĩnh, Sơn Thái, Trạm kiểm lâm Hòn Giao, forest behind the Nat. Park Headquarter $(1,630 \mathrm{~m}) 12^{\circ} 11^{\prime} 09.4^{\prime \prime} \mathrm{N}, 108^{\circ} 42^{\prime} 51.8^{\prime \prime} \mathrm{E}$, leg. HUNYADI \& OTANI, 06.02.2019, coll. HA; 2019/16. Khánh Hòa Province, Khánh Vĩnh, Khánh Phú, Thác Yang Bay, (90 m), 12¹1'27.1"N, 108 54'37.0"E, leg. HUNYADI \& OTANI, 07.02.2019, coll. HA; 2019/33. Quảng Nam Province, Nam Giang, Thạnh Mỹ 9 km - A Sơ, Hồ Chí Minh (QL14) Highway, 1547'18.0"N, 10746'33.4"E, leg. HUNYADI, 16.02.2019, coll. HA.

Remarks. C. franzhuberi Thach, 2018, C. franzhuberi laosianus Thach, 2018 and C. suprafusca Möllendorff, 1898 do not differ from C. pachychila in important shell characters such as shell and aperture shape, and sculpture, therefore, we consider the three taxa above as junior synonyms of $C$. pachychila.

\section{Genus Chloritis H. Beck, 1837}

Helix (Chloritis) BECK 1837: 29.

\section{Chloritis huberi Thach, 2016}

Fig. 17

Chloritis huberi THACH 2016a: 72, figs 49, 407-410.

Chloritis huberi - INKHAVILAY et al. 2019: 150, fig. 60B.

Type examined. MNHN-IM-2014-6068 (paratype, Fig. 17). 


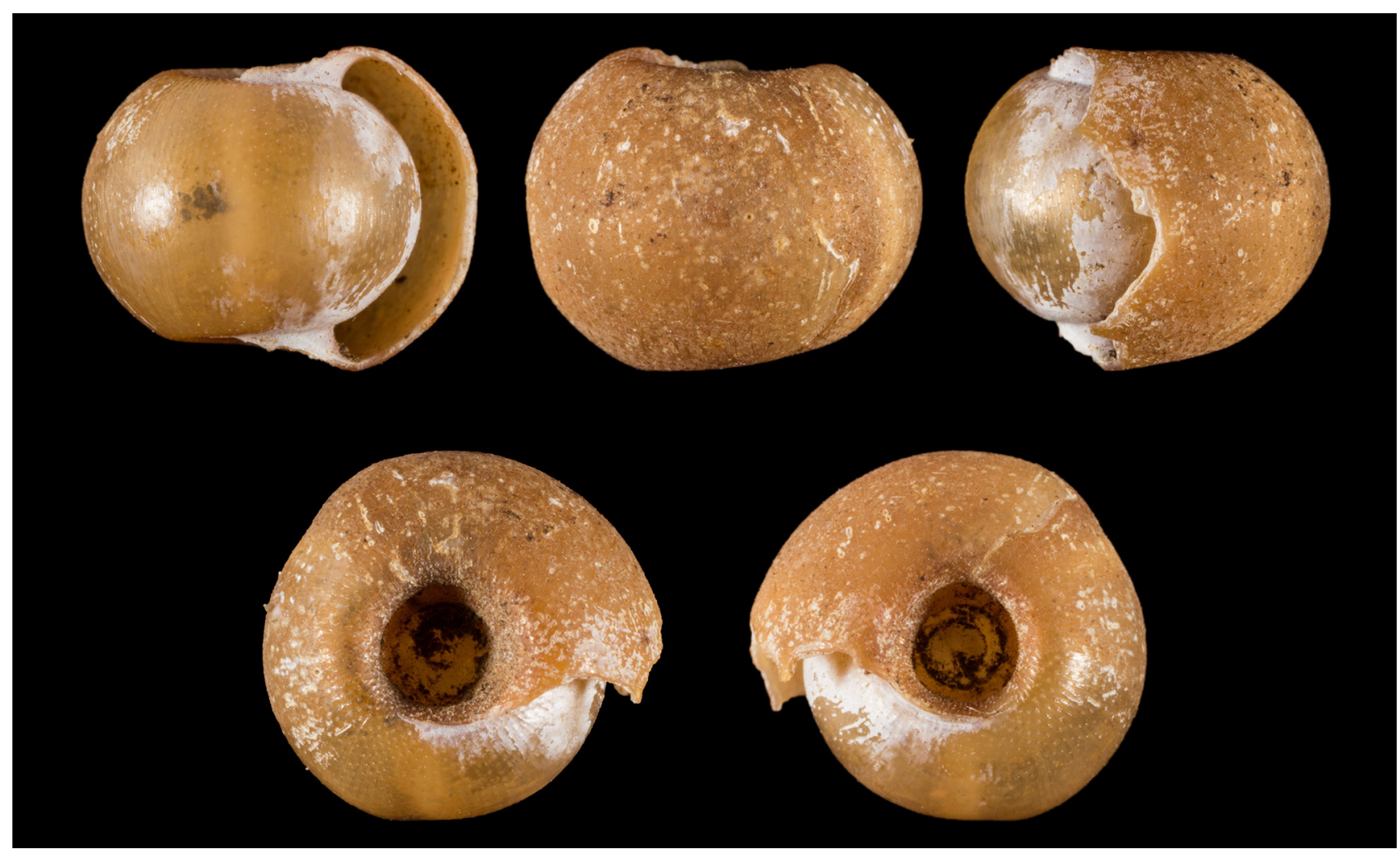

Fig. 17. Shells of paratype of Chloritis huberi Thach, 2016 (MNHN-IM-2014-6068). Photos: M. CABALLER

Remarks. The types are juvenile specimens not suitable for taxonomic comparison with possibly similar species known from adult individuals. Thus, this species is considered a taxon inquirendum.

\section{Chloritis khammouanensis Inkhavilay et \\ Panha, 2019}

Megalacron huberi THACH 2017a: 53, figs 741-743. Chloritis khammouanensis Inkhavilay et Panha in

INKHAVILAY et al. 2019: 100 (non Chloritis huberi

Thach, 2016, nomen novum pro Megalacron huberi Thach, 2017a)

New material examined. 6L07: South-Central Laos, Khammouan Province, ca. $9 \mathrm{~km} \mathrm{NE}$ of Thakhek (Muang Khammouan), on and under rocks in dry secondary forest under NW exposed cliff, $17^{\circ} 26^{\prime} 45.4^{\prime \prime} \mathrm{N}, 104^{\circ} 52^{\prime} 56.2^{\prime \prime} \mathrm{E}$, alt. $190 \mathrm{~m}$ a.s.l., leg. A. ABDOU \& I. V. MURATOV, 27.11.2007, MNHN-IMIM-2012-27068/33 adult shells (some broken), 17 juvenile shells; 5L07: South-Central Laos, Khammouan Province, ca. $22.5 \mathrm{~km}$ ENE of Thakhek (Muang Khammouan), ca. $19.5 \mathrm{~km}$ WNW of Mahaxai, under rocks in dry secondary forest, $17^{\circ} 26^{\prime} 43.2^{\prime \prime} \mathrm{N}$, $105^{\circ} 01^{\prime} 11.4^{\prime \prime E}$, alt. $181 \mathrm{~m}$ a.s.l., leg. A. ABDOU \& I. V. MURATOV, 27.11.2007, MNHN-IM 2012-27069/7 intact, 2 broken shells; 14L07: South-Central Laos, Khammouan Province, ca. $34 \mathrm{~km}$ WNW of Thakhek (Muang Khammouan), ca. $9 \mathrm{~km} \mathrm{~N}$ of Ban Namdik, on and under rocks in dry secondary forest with some large trees under $\mathrm{W}$ exposed cliff and in the ravine, leg. A. ABDOU \& I. V. MURATOV, 03.12.2007, MNHNIM 2012-27070/3 shells, MNHN-IM 2012-27073/1 intact, 1 broken shell; 19L07: South-Central Laos, Khammouan Province, ca. $4 \mathrm{~km} \mathrm{~W}$ of Ban Phong Dong, less than $1 \mathrm{~km} \mathrm{~S}$ of road 12, across the Houei Ine River, on and under rocks in secondary forest with some large trees on $\mathrm{N}$ exposed slope, $17^{\circ} 34^{\prime} 20.9^{\prime \prime} \mathrm{N}$, 105'38'36.6"E, alt. $191 \mathrm{~m}$ a.s.l., leg. A. ABDOU \& I. V. MURATOV, 06.12.2007, MNHN-IM 2012-27071/1 shell, MNHN-IM 2012-27076/1 shell; 17L07: SouthCentral Laos, Khammouan Province, ca. $12.5 \mathrm{~km} \mathrm{NE}$ of Thakhek (Muang Khammouan), ca. $3 \mathrm{~km} \mathrm{SW}$ of Ban Nase, on and under rocks in secondary forest with some large trees under SE exposed cliff, $17^{\circ} 29^{\prime} 50.5^{\prime \prime} \mathrm{N}$, $104^{\circ} 51^{\prime} 58.3^{\prime \prime E}$, alt. $193 \mathrm{~m}$ a.s.l., leg. A. ABDOU \& I. V. MuRATOV, 04.12.2007, MNHN-IM 2012-27072/1 shell; 10L07: South-Central Laos, Khammouan Province, ca. $14 \mathrm{~km} \mathrm{~N}$ of Thakhek (Muang Khammouan), ca. $5.5 \mathrm{~km}$ ESE of Ban Nakok, on and under limestone rocks in dry secondary forest under $\mathrm{N}$ exposed cliff, $17^{\circ} 31^{\prime} 24.8^{\prime \prime} \mathrm{N}, 104^{\circ} 48^{\prime} 14.9^{\prime \prime} \mathrm{E}$, alt. 133 m a.s.l., leg. A. ABDOU \& I. V. MuRATOV, 30.11.2007, MNHN-IM 2012-27074/2 intact, 2 broken shells; 8L07: South-Central Laos, Khammouan Province, ca. $16 \mathrm{~km}$ NE of Thakhek (Muang Khammouan), ca. $2.3 \mathrm{~km}$ ESE of Ban Nase, on and under limestone rocks in dry secondary forest with some large old trees in the isolated limestone outcrop, $17^{\circ} 30^{\prime} 49.7^{\prime \prime} \mathrm{N}$, $104^{\circ} 54^{\prime} 20.3^{\prime \prime} E$, alt. $162 \mathrm{~m}$ a.s.l., leg. A. ABDOU \& I. V. MURATOV, 28.11.2007, MNHN-IM 2012-27075/16 
shell (some slightly broken); 25L07: South-Central Laos, Khammouan Province, ca. $10.5 \mathrm{~km}$ E of Thakhek (Muang Khammouan), on and under rocks, cave deposits, in secondary forest under entrance and in large cave on NE exposed steep slope, $17^{\circ} 24^{\prime} 20.4^{\prime \prime} \mathrm{N}$, $104^{\circ} 54^{\prime} 53.6^{\prime \prime E}$, alt. $160 \mathrm{~m}$ a.s.l., leg. A. ABDOU \& I. V. MURATOV, 09.12.2007, MNHN-IM 2012-27077/4 shells; 24L07: South-Central Laos, Khammouan Province, ca. $22 \mathrm{~km}$ NNW of Thakhek (Muang Khammouan), ca. $5.5 \mathrm{~km}$ NNE of Ban Nakok, ca. $7 \mathrm{~km}$ ESE of Ban Namdik, under rocks in secondary forest under SW exposed cliff, $17^{\circ} 35^{\prime} 13.4^{\prime \prime} \mathrm{N}, 104^{\circ} 45^{\prime} 58.8^{\prime \prime} \mathrm{E}$, alt. $165 \mathrm{~m}$ a.s.l., leg. A. ABDOU \& I. V. Muratov, 08.12.2007, MNHN-IM 2012-27078/2 shells; 11L07: South-Central Laos, Khammouan Province, ca. 15 km ENE of Thakhek (Muang Khammouan), on and under limestone rocks in dry secondary forest in the upper entrance of the large cave on NW exposed steep slope, $17^{\circ} 26^{\prime} 39.0^{\prime \prime} \mathrm{N}, 104^{\circ} 56^{\prime} 56.6^{\prime \prime} \mathrm{E}$, alt. $157 \mathrm{~m}$ a.s.l., leg. A. ABDOU \& I. V. Muratov, 01.12.2007, MNHN-IM 2012-27079/3 intact, 6 broken shells; 9L07: South-Central Laos, Khammouan Province, ca. $13.5 \mathrm{~km} \mathrm{~N}$ of Thakhek (Muang Khammouan), ca. 5 $\mathrm{km}$ SE of Ban Nakok, under limestone rocks in dry secondary forest under $\mathrm{W}$ exposed cliff, $17^{\circ} 30^{\prime} 59.0^{\prime \prime} \mathrm{N}$, $104^{\circ} 47^{\prime} 40.9^{\prime \prime}$, alt. $138 \mathrm{~m}$ a.s.l., leg. A. ABDOU \& I. V. MURATOV, 30.11.2007, MNHN-IM 2012-27080/10 adult shells +2 juvenile shells; 12L07: Central Laos, southern Khammouan Province, ca. $15.5 \mathrm{~km}$ ENE of Thakhek (Muang Khammouan), on and under limestone rocks in dry secondary forest under NW exposed cliff, $17^{\circ} 26^{\prime} 49.0^{\prime \prime} \mathrm{N}, 104^{\circ} 57^{\prime} 12.0^{\prime \prime} \mathrm{E}$, alt. $155 \mathrm{~m}$ a.s.l., leg. A. ABDOU \& I. V. Muratov, 01.12.2007, MNHN-IM 2012-27081/4 shells; 4L07: SouthCentral Laos, Khammouan Province, ca. $35 \mathrm{~km}$ ENE of Thakhek (Muang Khammouan), ca. $7 \mathrm{~km}$ WNW of Mahaxai, on and under rocks in dry secondary forest under S exposed cliff, $17^{\circ} 26^{\prime} 44.2^{\prime \prime} \mathrm{N}, 105^{\circ} 08^{\prime} 21.6^{\prime \prime} \mathrm{E}$, alt. $169 \mathrm{~m}$ a.s.l., leg. A. ABDOU \& I. V. MURATOV, 25.11.2007, MNHN-IM 2012-27082/4 shells; 25L07, MNHN-IM 2012-27083/1 shell; 7L07: South-Central Laos, Khammouan Province, ca. $15 \mathrm{~km}$ NE of Thakhek (Muang Khammouan), ca. $12.5 \mathrm{~km}$ SE of Ban Nase, on and under rocks in dry secondary forest near large flooded cave under W exposed cliff, $17^{\circ} 30^{\prime} 32.8^{\prime \prime} \mathrm{N}$, $104^{\circ} 53^{\prime 2} 26.6^{\prime \prime E}$, alt. $127 \mathrm{~m}$ a.s.l., leg. A. ABDOU \& I. V. MURATOV, 28.11.2007, MNHN-IM-IM-2014-6129/36 adult shells and 18 juvenile shells.

Remarks. This species was described from Thakhek, Khammouan Province, Laos. Here we report it from several more localities in the same province.

\section{Chloritis klausgrohi Thach et Huber, 2017}

Chloritis klausgrohi Thach et Huber in THACH 2017a: 52, figs 729-730.

New material examined. Laos, Bam Na Ka Yak (Nhoum), ex coll. Saurin, MNHN-IM-2012-27090;
8L07: South-Central Laos, Khammouan Province, ca. $16 \mathrm{~km}$ NE of Thakhek (Muang Khammouan), ca. $2.3 \mathrm{~km}$ ESE of Ban Nase, on and under limestone rocks in dry secondary forest with some large old trees in the isolated limestone outcrop, $17^{\circ} 30^{\prime} 49.7^{\prime \prime} \mathrm{N}$, $104^{\circ} 54^{\prime} 20.3^{\prime \prime E}$, alt. $162 \mathrm{~m}$ a.s.l., leg. A. ABDOU \& I. V. MuRATOV, 28.11.2007, MNHN-IM-2012-27067/8 intact shells, 3 juvenile shells, 2 broken adult shells; 13L07: South-Central Laos, Khammouan Province, ca. $11.5 \mathrm{~km}$ ENE of Thakhek (Muang Khammouan), on and under rocks in dry secondary forest in the ravine and on the pass, $17^{\circ} 26^{\prime} 23.8^{\prime \prime} \mathrm{N}, 104^{\circ} 54^{\prime} 45.1^{\prime \prime} \mathrm{E}$, alt. $277 \mathrm{~m}$ a.s.l., leg. A. ABDOU \& I. V. Muratov, 01.12.2007, MNHN-IM-2012-27065/1 broken adult shell; 20L07: South-Central Laos, Khammouan Province, ca. $2 \mathrm{~km}$ SE of Ban Xieng Dao, less than 1 $\mathrm{km} \mathrm{S}$ of road 12, across the Houei Ine River, on and under rocks in secondary forest on large limestone outcrops, $17^{\circ} 34^{\prime} 43.3^{\prime \prime} \mathrm{N}, 105^{\circ} 32^{\prime} 58.8^{\prime \prime} \mathrm{E}$, alt. $200 \mathrm{~m}$ a.s.l., leg. A. ABDOU \& I. V. Muratov, 06.12.2007, MNHN-IM-2012-27064/1 intact shell, 3 adult, broken shells; 3L07: South-Central Laos, Khammouan Province, ca. $37 \mathrm{~km}$ ENE of Thakhek (Muang Khammouan), ca. $4.5 \mathrm{~km} \mathrm{WNW}$ of Mahaxai, on and under rocks in dry secondary forest under $\mathrm{E}$ exposed cliff, $17^{\circ} 25^{\prime} 57.4^{\prime \prime} \mathrm{N}, 105^{\circ} 09^{\prime} 40.1^{\prime \prime} \mathrm{E}$, alt. $150 \mathrm{~m}$ a.s.l., leg. A. ABDOU \& I. V. MURATOV, 25.11.2007, MNHNIM-2012-27088/10 broken shells/shell fragments; 4L07: South-Central Laos, Khammouan Province, ca. $35 \mathrm{~km}$ ENE of Thakhek (Muang Khammouan), ca. $7 \mathrm{~km}$ WNW of Mahaxai, on and under rocks in dry secondary forest under S exposed cliff, $17^{\circ} 26^{\prime} 44.2^{\prime \prime} \mathrm{N}$, $105^{\circ} 08^{\prime} 21.6^{\prime \prime E}$, alt. $169 \mathrm{~m}$ a.s.l., leg. A. ABDOU \& I. V. MuRATOV, 25.11.2007, MNHN-IM-2012-27089/14 adult, mostly intact shells and 2 juvenile shells.

Remarks. The type locality given in the original description was listed as Laos without further information. INKHAVILAY et al. (2019) reported the species from a locality in Khammouan Province. Here we report this species from several other localities in the same province.

\section{Chloritis vinhensis Thach et Huber, 2018 \\ Figs 18-25}

Chloritis bifoveata vinhensis Thach et Huber in THACH 2018a: 68, figs 900-902.

Material examined. 2019/27. Đà Nẵng, Hòa Vang, Đính Bà Nà, Cầu Vàng NE ca. 400 m a.s.l. (1270 m a.s.l.), 1559'45.8"N, 10759'56.7"E, leg. HuNYADI, 13.02.2019, coll. HA. (Fig. 19)

Remarks on the anatomy. Traits of the reproductive anatomy (Fig. 20), such as the proportions of the male organs and the insertion of the retractor muscle, are similar to those of C. bifoveata (Benson, 1856) and C. diplochone Möllendorff, 1898 (see: SUTCHARIT \& PANHA 2010: figs 3A, 3E vs. PÁll-Gergely \& 


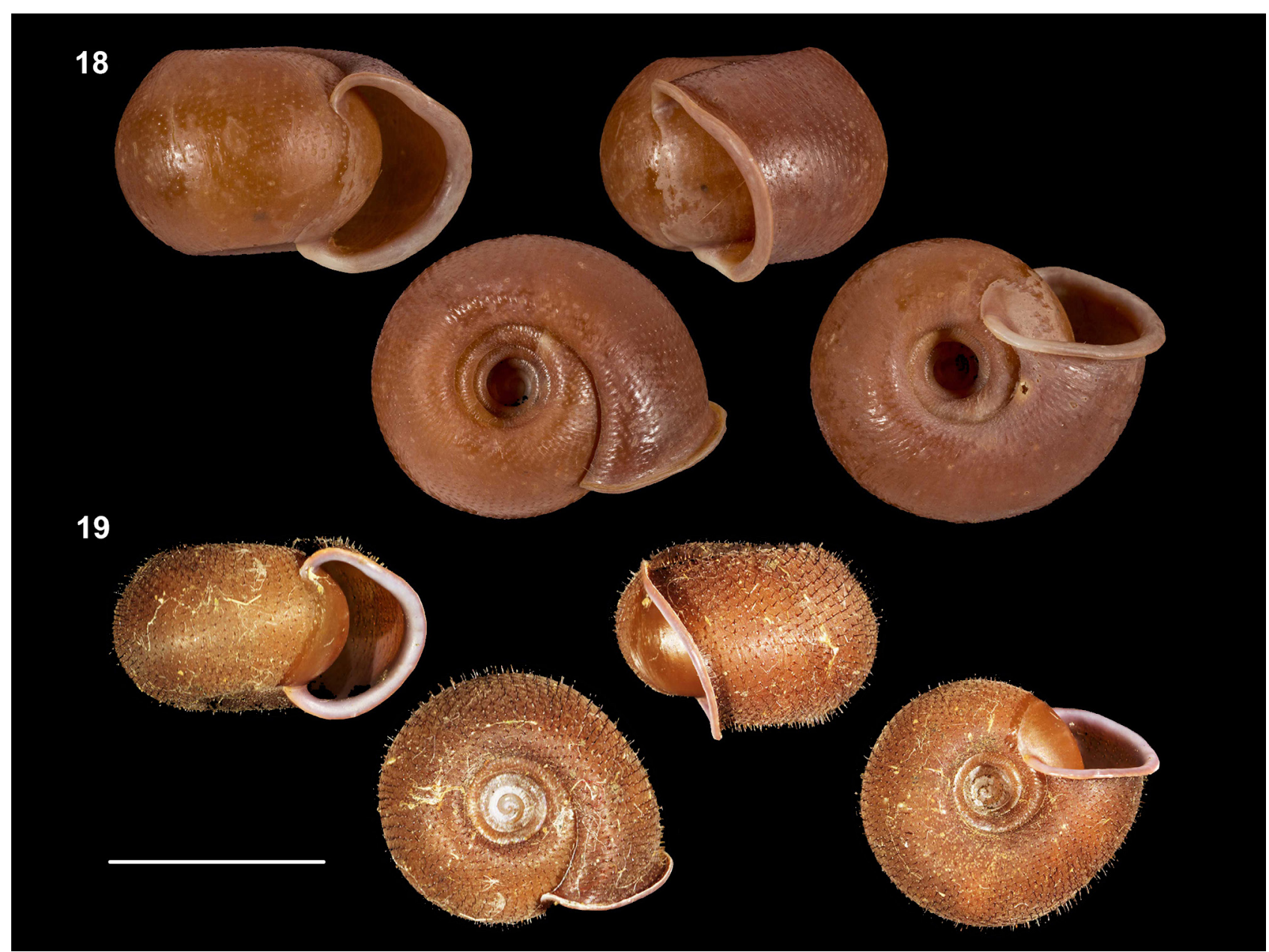

Figs 18-19. Shells of Chloritis vinhensis Thach et Huber, 2018: 18 - holotype (MNHN-IM-2000-34047); 19 - anatomically examined specimen. Photos: M. CABAller (18) and B. PÁlL-GERGELY (19). Scale bar $10 \mathrm{~mm}$

NEUBERT 2019: fig. 16 therein, Figs 21-25 herein). The main difference was found to be the structure of the penial papilla. In C. bifoveata and C. diplochone, it was described as "irregularly shaped" (SUTCHARIT \& PANHA 2010: figs 3B, 3F), and deeply grooved (PÁLLGERGELY \& NEUBERT 2019: fig. 17 therein, Figs 2123 here), whereas in the $C$. vinhensis specimen we dissected, the longitudinal folds of the epiphallus merge to a stalk which ends in a flattened knob with a terminal opening. This structure is surrounded by a fleshy rim. Given the differently shaped penial verge and the absence of constriction on the body whorl, we elevate $C$. bifoveata vinhensis to species level.

\section{Genus Ganesella Blanford, 1863}

Helix (Ganesella) BLANFORD 1863: 86.

Remarks. The type species of Ganesella (Helix capitium Benson, 1848) is a senior synonym of Darwininitium shiwalikianum Budha et Mordan, 2012, which was anatomically described in its original description (SUTCHARIT et al. 2019b). Thus, Ganesella is defined in terms of reproductive anatomy.
The placement of G. emma follows SCHILEYKO (2011), although we note that the generic placement of most Southeast Asian camaenids needs verification by means of anatomy and/or molecular phylogeny.

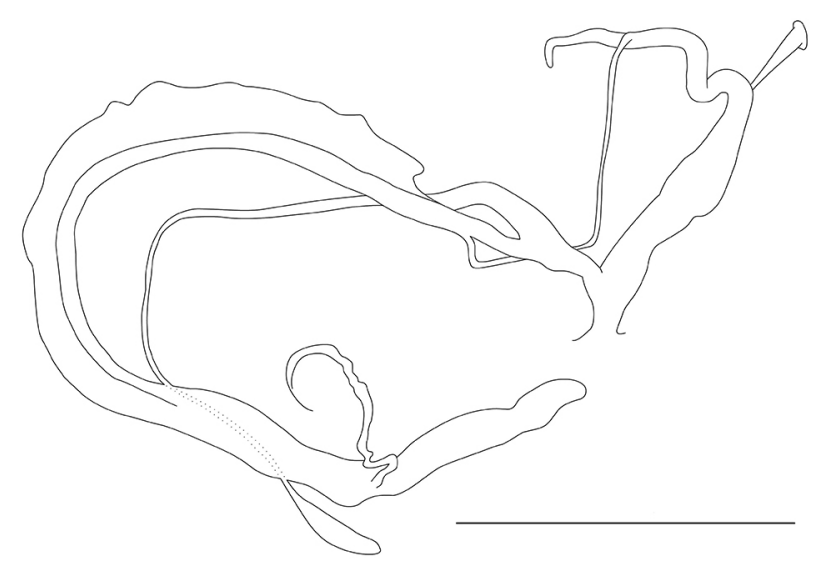

Fig. 20. Reproductive anatomy of Chloritis vinhensis Thach et Huber, 2018. Scale bar $10 \mathrm{~mm}$ 


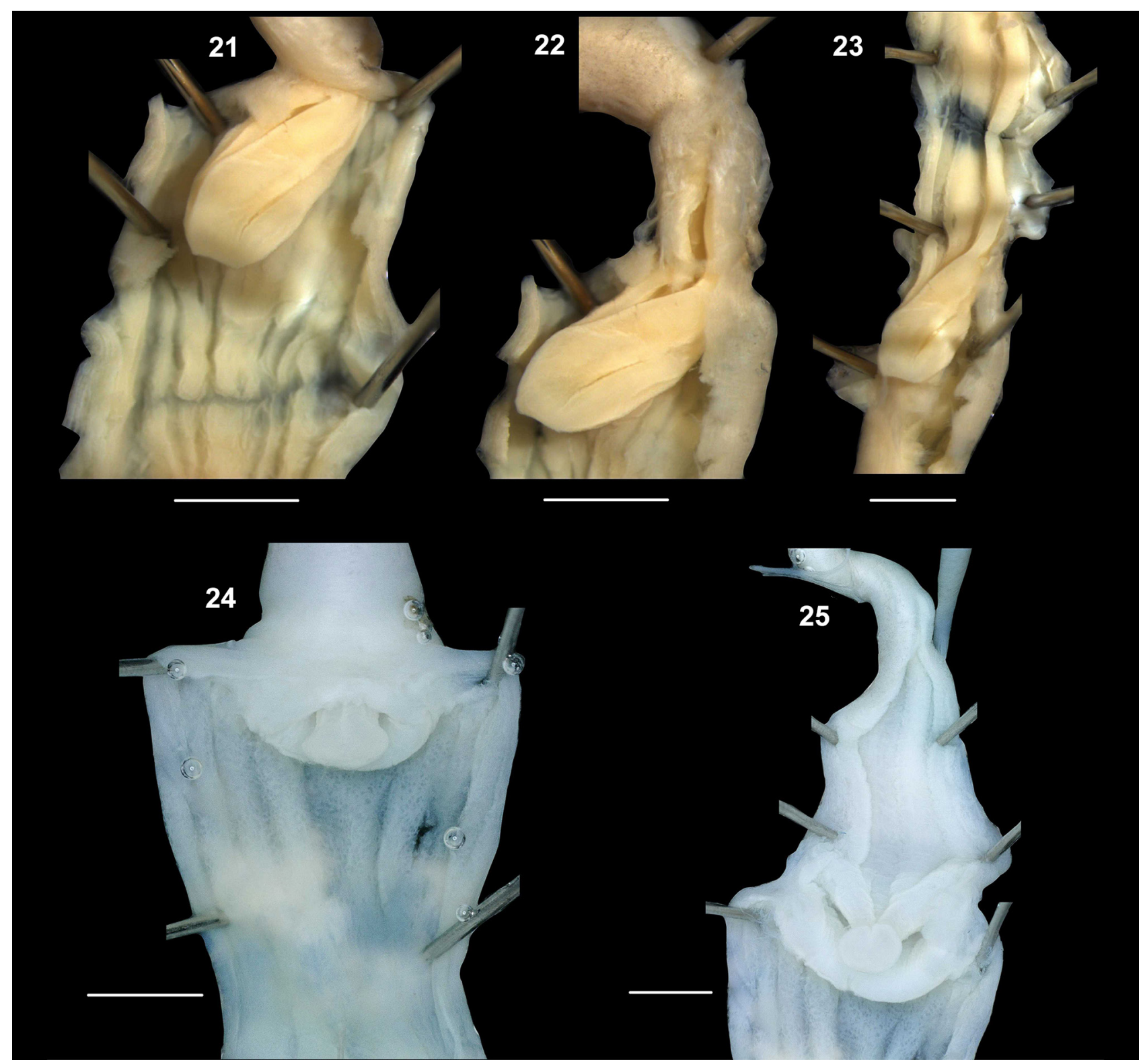

Figs 21-25. Penial papilla of Chloritis bifoveata (Benson, 1856) (21-23 - from PÁLL-GergeLY \& NeUBERT 2019) and Chloritis vinhensis Thach et Huber, 2018 (24-25). Scale bars $1 \mathrm{~mm}$. All photos: B. PÁlL-GergelY

\section{Ganesella emma (L. Pfeiffer, 1863)}

Figs 26-29

Helix emma L. PFEIFFER 1863: 273.

Helix (Ganesella?) lamyi DAUTZENBERG \& FISCHER 1905: 91, plate 3, figs 10-12. new synonym

Helix (Plectotropis?) chaudroni BAVAY \& DAUTZENBERG 1909a: 242. new synonym

Helix (Plectotropis?) chaudroni-BAVAY \& DAUTZENBERG 1909b: 193, plate VIII, figs 1-3.

Euplecta huberi ТHACH 2018a: 41, figs 551-553. new synonym

Types examined. Lao Mountains, Cambodia, coll. Mouhot, m.c. [Museum Cuming], NHMUK 20170016 (syntype of Helix emma, Fig. 26); Tonkin, Ile Krieu, baie d'Along, leg. BLAISE, MNHN-IM-2000-1920 (syntype of Helix (Ganesella?) lamyi, Fig. 27); CamDuong, Phong-Tho, Gia Phu, leg. Messager, MNHNIM-2000-32867 (syntype of Helix (Plectopylis?) chaudroni, Fig. 28); Bosavan, Laos, MNHN-IM-2000-34093 (holotype of Euplecta huberi, Fig. 29).

Remarks. The type specimens of H. emma L. Pfeiffer, 1863, H. (Plectotropis?) chaudroni Bavay et Dautzenberg, 1909, H. (Ganesella?) lamyi (Dautzenberg et Fischer 1905) and E. huberi Thach, 2018 differ only in minor shell characters, such as the height of the spire, and the arrangement of the white bands between the keel and the suture. Although these four taxa were placed in different genera, their differences can be explained by intraspecific variability only, because the overall shell shape, colouration and sculpture are identical. Therefore, we regard H. chaudroni, 
H. lamyi and Euplecta huberi as junior synonyms of Ganesella emma.

\section{Ganesella rhombostoma (L. Pfeiffer, 1861)}

Bulimus rhombostomus L. PFEIFFER 1861: 194, 195

Pseudobuliminus harryleei THACH 2017a: 54, 55, figs 756-760.

Pseudobuliminus tuongvyae THACH 2017a: 56, figs 751755.

Pseudobuliminus huberi THACH 2017a: 55, figs 759-760. Ganesella rhombostoma SUTCHARIT et al. 2019b: 61, figs 1C, 3C-I, 5E-G, 7D-F, 8 (harryleei, tuongryae and huberi are considered synonyms)
Remarks. THACH described 8 species of Pseudobuliminus Gredler, 1886 as follows: P. franzhuberi Thach, 2018, P. harryleei Thach, 2017, P. huberi Thach, 2017, P. maestratii Thach, 2017, Thach, 2017a, P. obesa Thach et Huber, 2018, P. ovoideus Thach et Huber, 2018, P. thachi Huber, 2018, P. tuongvyae Thach, 2017. Pseudobuliminus harryleei, $P$. tuongvyae and P. huberi were synonymised with G. rhombostoma by SUTCHARIT et al. (2019b) without explanation, although we agree with their decision. The genera Pseudobuliminus and Giardia Ancey, 1907 have not been revised, and the species are known to exhibit great variability in terms of shell size (SCHILEYKO 2011), and probably

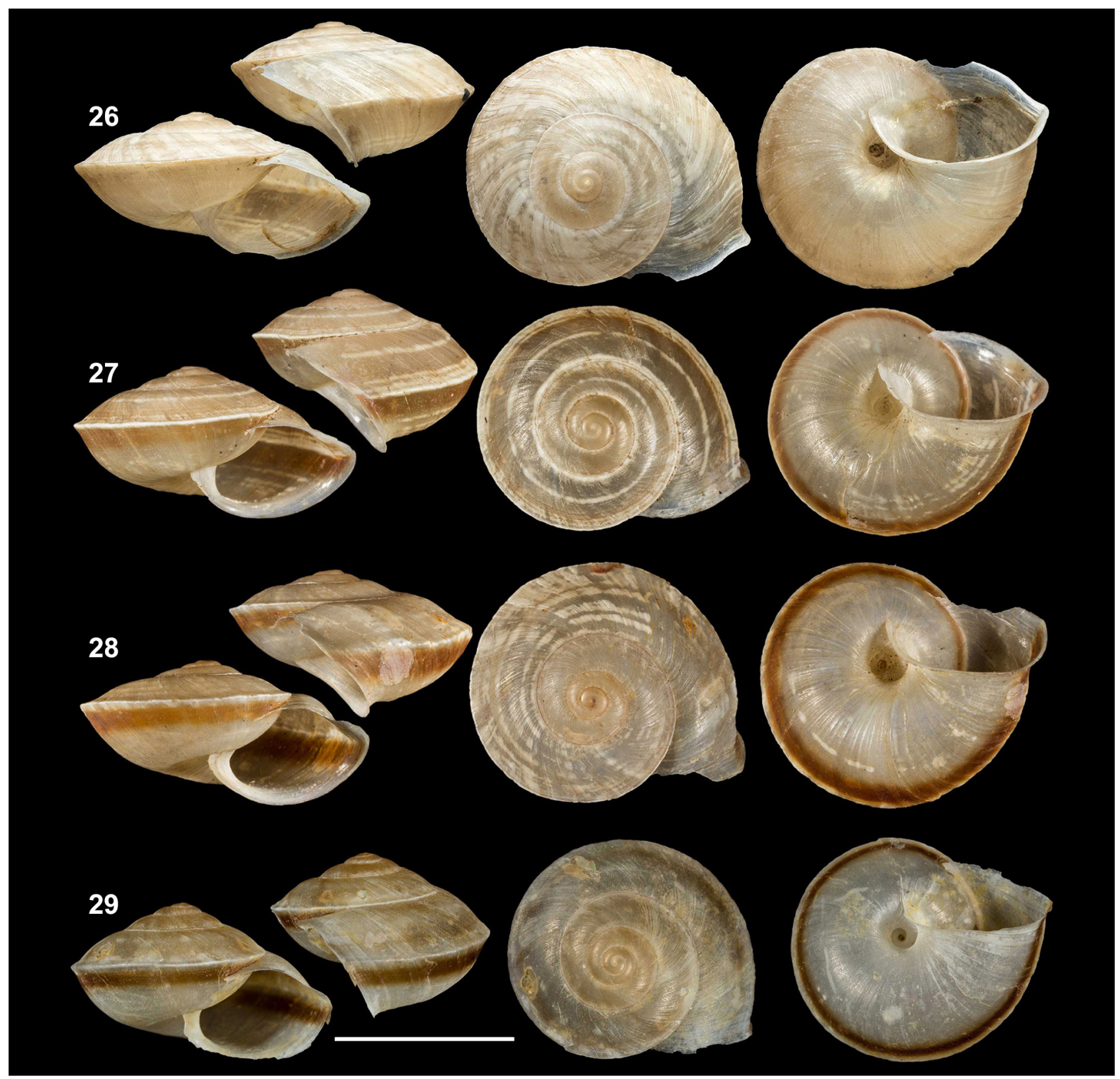

Figs 26-29. Shells of Ganesella emma (L. Pfeiffer, 1863: 26 - syntype of Helix emma L. Pfeiffer, 1863 (NHMUK 20170016); 27 - Helix (Ganesella?) lamyi Dautzenberg et Fischer, 1905 (MNHN-IM-2000-1920); 28 - Helix (Plectotropis?) chaudroni (MNHN-IM-2000-32867); 29 - holotype of Euplecta huberi Thach, 2018. Scale bar 10 mm. Photos: H. TAYLOR (26) and M. CABALLER (27-29) 
other characters. Therefore, most likely, the remaining taxa of Thach and Huber will be considered synonyms upon comprehensive revisions.

G. rhombostoma was classified in Amphidromus and Giardia, although SUTCHARIT et al. (2019b), based on anatomical evidence, transferred it to Ganesella.

\section{Ganesella rostrella (L. Pfeiffer, 1863)}

Helix rostrella L. PFEIFFER 1863: 270.

Euplecta hueae Thach et Huber in THACH 2018a: 42, figs 557-559. new synonym

Bradybaena (?) rostrella - SCHILEYKO 2011: 40.

Ganesella rostrella - INKHAVILAY et al. 2019: 104, figs 53B-C.

Types examined. Cambodia, Museum Cuming ex. Mouhot collection NHMUK 20130217 (3 syntypes of Helix rostrella).

Remarks. E. hueae Thach et Huber, 2018 was described as a member of the family Ariophantidae. However, it is nearly identical to typical G. rostrella, although the spire of typical specimens is slightly more elevated. This difference should not be used as a distinguishing character at the species level. We herein consider $E$. hueae a junior synonym of $G$. rostrella.

\section{Genus Globotrochus Haas, 1935}

Globotrochus HAAS 1935: 47.

Globotrochus - SUTCHARIT et al. 2019b: 66.

\section{Globotrochus onestera (Mabille, 1887)}

Helix onestera MABILLE 1887: 3.

Diastole simonei THACH 2017a: 34, figs 418-420.

Globotrochus onestera - SUTCHARIT et al. 2019b: 67, figs 1D, 4E-G, 6, 7G-I, 8 (considered Diastole simonei as a junior synonym).

Remarks. In the original description, D. simonei Thach, 2017 was only compared to another Diastole species, "Diastole rectangular (L. Pfeiffer, 1846)" (probably Mendana rectangula (L. Pfeiffer, 1846)). However, Diastole Gude, 1913 is known only from islands of the Pacific Ocean (Society, Cook, Samoa, Futuna, Fiji, Tonga, Tuamotu, Norfolk and Austral Islands), and belongs to the family Euconulidae $\mathrm{H}$. B. Baker, 1928 (SCHILEYKO 2002). In contrast, "D. simonei" is a camaenid species, and its type locality (northern Vietnam) makes the generic assignment of THACH (2017a) biogeographically inexplicable. We agree with SUTCHARIT et al. (2019b), and consider D. simonei as a junior synonym of $H$. onestera.

\section{Genus Trichochloritis Pilsbry, 1891}

Trichochloritis PILSBRY 1891: 267.

Trichochloritis - PÁLL-GERGELY \& NEUBERT 2019: 141.

Trichochloritis fouresi Morlet, 1886

Figs 30-32
Helix fouresi MORLET 1886: 74.

Euplecta herosae Thach et Huber in THACH 2018a: 42, figs 554-556. new synonym

Bouchetcamaena huberi THACH 2018a: 65, figs 863-865. new synonym

Chloritis fouresi - INKHAVILAY et al. 2019: 100, figs 50C-D.

Types examined. Plateau de Stang-Trang, Cambodia, leg. PAVIE, MNHN-IM-2000-1888 (syntype of fouresi, Fig. 30); South of Pakse, Champasak Province, South Laos, MNHN-IM-2000-34039 (holotype of Bouchetcamaena huberi, Fig. 31); Boloven Plateau, South Laos, MNHN-IM-2000-34040 (holotype of Euplecta herosae, Fig. 32); Siam, m.c. [Museum Cuming], NHMUK 20160333 (3 syntypes of caseus); Kamchay, Cambodia, leg. MORLET, MNHNIM-2000-1953 (holotype of norodomiana); FuyenMoth [Phú Yen Province, S Vietnam, $14^{\circ} 01^{\prime} \mathrm{N}$, $108^{\circ} 23^{\prime} \mathrm{E}$, see: SCHILEYKO 2011], leg. CROSSE, MNHN-IM-2000-31779 (syntype of tanquereyi); Same data, MNHN-IM-2000-31780 (syntype of tanquereyi var. intermedia); Same data, MNHN-IM-2000-31781 (syntype of tanquereyi var. minima); W-Siam, Kanburi, coll. O. Möllendorff ex coll. Fruhstorfer, SMF 8598 (lectotype of siamensis); Same data, SMF 8602/2 (paralectotypes of siamensis); Siam, Tschaya, coll. O. Möllendorff ex coll. Roebelen, SMF 8526/1 (lectotype of platytropis); Same data, SMF 8527/1 (paralectotype of platytropis); Golf von Siam, Insel Samui, coll. O. Möllendorff ex coll. Roebelen, SMF 8524/1 (lectotype of platytropis var. samuiana); Same data, SMF 8525/1 (paralectotype of platytropis var. samuiana).

Remarks. In the original description, B. huberi Thach, 2018 was compared to two species, Camaena vanbuensis Smith, 1896 and Eurytrachia mucosa (Cox, 1868). Although the shell shape of C. vanbuensis is superficially similar to that of $B$. huberi, it is $68 \mathrm{~mm}$ in diameter (SCHILEYKO 2011, INKHAVILAY et al. 2019) compared to $18.5 \mathrm{~mm}$ in diameter for B. huberi, making it highly unlikely that they are closely related. E. mucosa lives in eastern Australia (STANISIC et al. 2010), a biogeographic region that has virtually no taxa in common with that of southern Laos, where the type locality of $B$. huberi is located. In contrast, $B$. huberi was not compared to a number of taxa with similar shell morphology described from Thailand, Cambodia, and southern Vietnam (e.g. Helix caseus L. Pfeiffer, 1860, H. norodomiana Morlet, 1883, Chloritis siamensis Möllendorff, 1902, Helix tanquereyi Crosse et Fischer, 1863 and its varieties, and Chloritis platytropis Möllendorff, 1894).

Besides slight differences in shell height, which can be best explained by intraspecific variability, there are no essential differences between the type specimens of Helix fouresi Morlet, 1886, E. herosae Thach et 


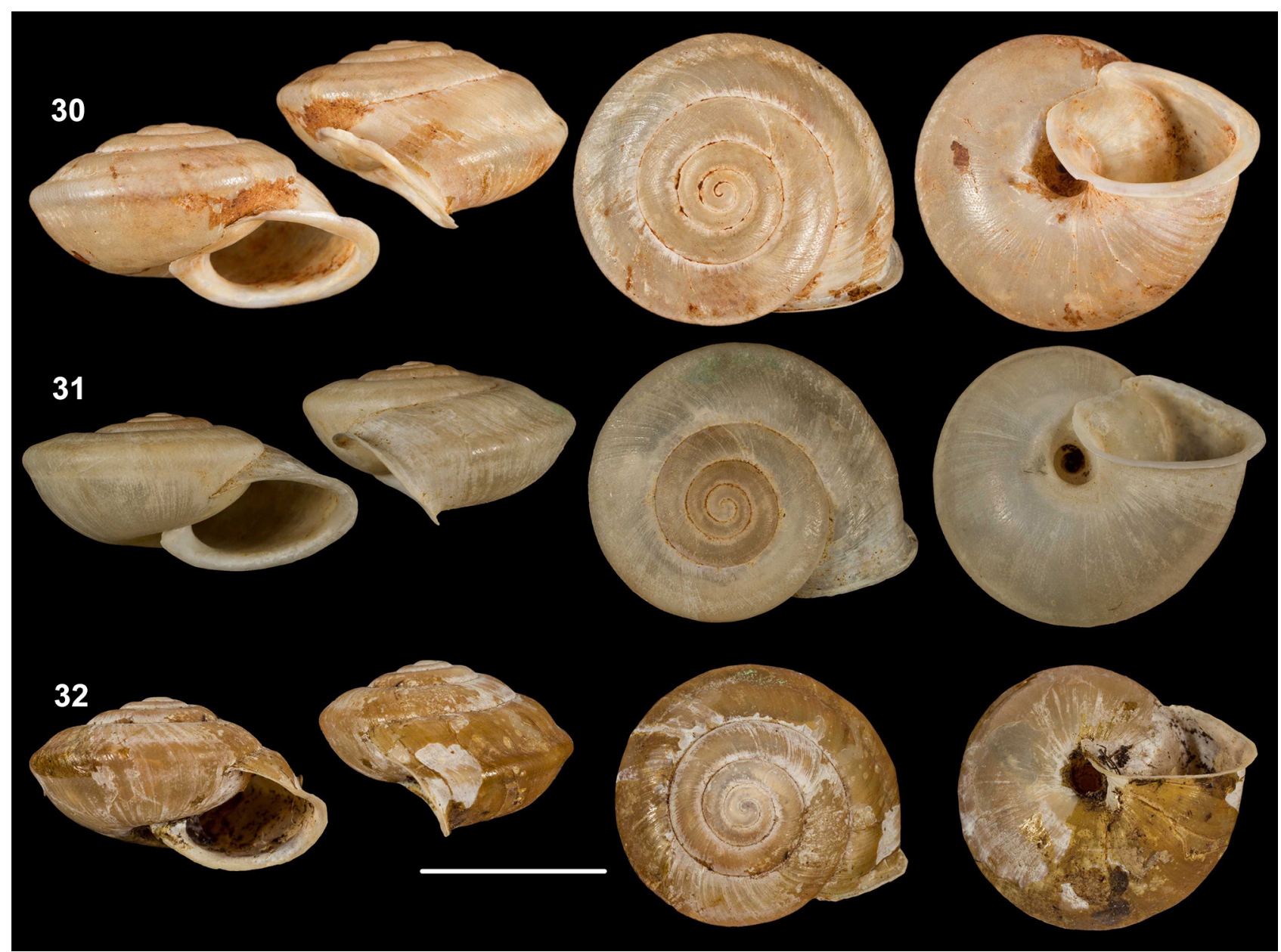

Figs 30-32. Shells of Trichochloritis fouresi Morlet, 1886: 30 - syntype of Helix fouresi Morlet, 1886 (MNHN-IM-2000-1888); 31 - holotype of Bouchetcamaena huberi Thach, 2018 (MNHN-IM-2000-34039); 32 - holotype of Euplecta herosae Thach et Huber, 2018 (MNHN-IM-2000-34040). Scale bar 10 mm. Photos: M. CABALLER

Huber, 2018 and B. huberi Thach, 2018, therefore the latter two are synonyms of the former.

The validity of the genus Bouchetcamaena can be verified when more material becomes available.

Trichochloritis huberi (Thach, 2018) new combination

Lamprellia huberi THACH 2018a: 70, figs 971-973.

Remarks. This species was originally assigned to the genus Lamprellia Stanisic, 2010 (type species: Helix zebina Brazier, 1878), which is endemic to eastern Australia, and was only compared with a Lamprellia species (L. angulata Stanisic, 2010). However, there are a number of similar species described from Cambodia, Vietnam, and Laos in more appropriate genera. This species is very similar to the type spe- cies of Trichochloritis (Helix breviseta L. Pfeiffer, 1862) in terms of general shell and aperture shape, but differs from it by the angled body whorl, which is rounded in T. breviseta. Therefore, it is transferred here to Trichochloritis.

\section{Trichochloritis mussonena Páll-Gergely, 2020} nom. nov.

Mussonena huberi THACH 2018a: 70, figs 919-921.

Remarks. Mussonena Iredale, 1938 is distributed in eastern Australia, not Southeast Asia (SCHILEYKO 2003). This species is moved to Trichochloritis herein, and becomes a secondary homonym of T. huberi (Thach, 2018) (see: THACH 2018a: 70). Therefore, the replacement name, T. mussonena, referring to the original generic name, is proposed.

\section{DISCUSSION}

WHEELER (2014: 371) summarised the specific traits of a taxonomist as follows: "If the focus of your work is to make as many species of a clade known as possible, to carefully interpret and analyse the transformational history of as many of its homologous characters as possible, to study and master 
all taxonomic literature on a group since 1753 , to apply informative names, and to ultimately build a phylogenetic classification summarizing all that is known of a taxon, then you are unquestionably a taxonomist." Unfortunately, the authors discussed here have not followed these guidelines in their mostly non-peer-reviewed descriptions of more than three hundred species and subspecies over the last 5 years (2014-2019).

Ideally, the purpose to describe an unknown species or subspecies is to contribute to the knowledge of the biodiversity of our planet. However, these descriptions must be presented to the scientific community in a consistent and accepted manner, i.e. a peer-reviewed journals and books. Why do some authors choose not to adhere to the accepted formats, i.e. present new taxa in non-peer-reviewed publications, even when they have interest in biodiversity?

Time and effort are surely factors. Some authors simply do not want to take the time or apply the effort necessary to complete the peer-review process. They may also believe that review is unnecessary because no one knows more about the subject so why should it be reviewed? Also, some degree of fame and respect comes with the introduction of new taxa and this increases as the number of taxa described increases. This is a well-known phenomenon already described as nomenclatural mihilism (DUBOIs 2008) and "Mihi itch" (EVENHUIS 2008). And, finally, some invertebrate groups such as molluscs, butterflies, beetles, corals, etc. are widely collected by enthusiasts worldwide. These are traded, bought, and sold and this has become a huge industry in many parts of the world. Specimens with attractive colours and colour patterns are particularly sought after and supply and demand forces values up (and profits). Value is also greatly determined by rarity. So, new taxa described, particularly those with attractive colour patterns and small distributions, drive interest and desire in enthusiasts to enhance their collections with species that no other collector possesses. For the seller, new names create more taxa to inventory and sell, even when the taxa represent nothing but intra-specific variation. Some authors retain or give type specimens to the collector instead of depositing them in recognised institutions. These specimens have much higher value than non-typical material if sold. Some collectors, but surely not all, that provide specimens to those that may describe them as new taxa are sometimes motivated by two purposes: 1) potential future financial gain, and 2) the naming of patronyms. The latter has certainly occurred.

For whatever reasons, Nguyen Ngoc Thach and his colleagues described over three hundred species over the last five years, mostly land snails from Southeast Asia, almost all without peer review. Our estimate is that ca. $30-40$ species of their terrestrial taxa are valid (less than 15\% of all of the newly described taxa!), although we are unable to judge in many cases with the general lack of generic revisions. Similar to the activity of the Australian "herpetologist" R. Hoser (KAISER et al. 2013, DENZER et al. 2016) and some other pseudo-taxonomists (see e.g. MOORE et al. 2014), the hundreds of taxon names introduced by these authors simply must be considered unacceptable and marked as taxonomic vandalism. Although the community of taxonomists rejects the concept of more bureaucracy over taxonomy (GARNETT \& CHRISTIDIS 2017, THOMSON et al. 2018), it seems inevitable to require peer-review for the description of new taxa and other taxonomic decisions to be acceptable as valid (e.g. KAISER et al. 2013, SCHUTZE et al. 2017).

\section{ACKNOWLEDGEMENTS}

We are grateful for VIRGINIE HÉros and PHILIPPE BOUCHET (MNHN), JONATHAN ABLETT (NHM), SIGRID HOF and RONALD JANSSEN (SMF) for granting access to their museum collections to BRAM VAN DER BIJL (RMNH) for lending us holotypes, to MIKLós SZEKERES and OWEN GRIFFITHS for providing important information, to M. CABALLER (MNHN) for photographing type specimens (project E-RECOLNAT: ANR-11-INBS-0004) and to three reviewers for their comments on the manuscript. This study was supported by the MTA (Hungarian Academy of Sciences) Premium Post Doctorate Research Program for BPG.

\section{REFERENCES}

Aввотт R. T. 1989. Compendium of landshells. A full color guide to more than 2,000 of the World's terrestrial shells. American Malacologists, Inc., Melbourne, Florida.

Albers J. C. 1850. Die Heliceen nach natürlicher Verwandtschaft systematisch geordnet. Enslin, Berlin.

ANCEY C. F. 1884. Sur les divisions proposées dans le genre Streptaxis. Le Naturaliste 6(50): 399.

ANCEY C. F. 1887. Description of new genera or subgenera of Helicidæ. The Conchologists' Exchange 1(9-10): 53-54, 1(12): 75-76; 2(3): 38-39.

ANCEY C. F. 1897. On two new species of Amphidromus. The Nautilus 11: 62-63.

ANCEY C. F. 1898. Notes malacologiques. A - Observation sur les mollusques terrestres et fluviatiles recueillies dans l'Indo-Chine et particulièrement au Laos par Henri Counillon. B - Description d'espèces nouvelle du centre 
d'Afrique. C - Notes sur quelques coupes génériques ou sous-génériques de Mollusques. D - Description d'un mollusque méditerranéen nouveau. Bulletin du Musée d'Histoire Naturelle de Marseille Série II 1(1): 125-150.

ANCEY C. F. 1904. Notes critiques et synonymiques. Journal de Conchyliologie 52: 288-316.

ANCEY C. F. 1907. Observations sur les mollusques gastéropodes sénestres de l'epoque actuelle. Bulletin Scientifique de la France et de la Belgique 40: 187-205.

AZUMA M. 1980. Description of a new species of the genus Awalycaeus Kuroda, 1915, (Family Cyclophoridae) from Mt. Sarumasa, Shimane Pref., Japan. Venus (Japanese Journal of Malacology) 39: 139-141.

BAIRD W. 1850. Nomenclature of molluscous animals and shells in the collection of the British Museum. Part I. Cyclophoridae. Spottiswoodes and Shaw, New-StreetSquare, London.

BAVAY A., DAUTZENBERG P. 1904. Description de coquilles nouvelles de l'Indo-Chine. (3e suite). Journal de Conchyliologie 51: 201-236. ["1903”]

BAVAY A., DAUTZENBERG P. 1909a. Molluscorum terrestrium Tonkinorum diagnoses. Journal de Conchyliologie 56: 229-251. ["1908"]

BAVAY A., DAUTZENBERG P. 1909b. Description de coquilles nouvelles de l'Indo-Chine. Journal de Conchyliologie 57: 81-105, 163-206, 279-288.

BAVAY A., DAUTZENBERG P. 1912. Description de coquilles nouvelles de l'Indo-Chine. Journal de Conchyliologie 60: 1-54.

BECK H. 1837. Index molluscorum praesentis aevi musei principis augustissimi Christiani Frederici. Hafniae, Copenhagen.

BentheM JutTING W. S. S. VAN 1959. Catalogue of the non-marine Mollusca of Sumatra and of its satellite islands. Beaufortia 7: 41-191.

BENTHEM JuTtiNG W. S. S. VAN 1960. Some notes on land and freshwater Mollusca of Malaya. Basteria 24: 10-20.

BENSON W. H. 1834. Observations on a collection of land and freshwater shells formed in the Gangetic provinces of India. Proceedings of the Zoological Society of London 1834: 89-91.

BENSON W. H. 1848. Characters of seven new species of Helix, with amended descriptions of some species previously described, and notes on other requiring remark. Proceedings of the Zoological Society of London 16: 158-164.

BENSON W. H. 1860. On Clostophis and Rhiostoma, new Burmese genera of land-shells. The Annals and Magazine of Natural History, series 3, 5: 95-97.

BLANFORD W. T. 1863. On Indian species of land-shells belonging to the genera Helix, Linn., and Nanina, Gray. The Annals and Magazine of Natural History, series 3, 11: 80-86.

BLANFORD W. T. 1864. On the classification of the Cyclostomacea of Eastern Asia. The Annals and Magazine of Natural History, series 3, 13: 441-465.
BLANFORD W. T. 1872. Monograph of Himalayan, Assamese, Barmese and Cingalese Clausiliae. Journal of the Asiatic Society of Bengal 41: 199-206.

Bock C. 1881. List of land and freshwater shells collected in Sumatra and Borneo, with descriptions of new species. Proceedings of the Zoological Society of London (1881): 628-635.

Bui T. C., Do V. N., NGo D. C., Do D. S. 2019. The land snail family Streptaxidae J. Gray, 1860 from Thua Thien Hue, Vietnam, with description of two new species (Gastropoda: Pulmonata). Ruthenica 29: 87-94.

BOUCHET P., Rocroi J. P., HAUSDORF B., KaIM A., KANO Y., NÜTZEL A., PARKHAEV P., SCHRÖDL M., STRONG E. E. 2017. Revised classification, nomenclator and typification of gastropod and monoplacophoran families. Malacologia 61: 1-526. https://doi. org/10.4002/040.061.0201

BRAZIER J. 1878. Descriptions of seven new species of terrestrial and marine shells from Australia. Proceedings of the Linnean Society of New South Wales 3: 77-81.

Budha P. B., MORdAN P. B., NAGgS F., BACKelJaU T. 2012. Darwininitium - a new fully pseudosigmurethrous orthurethran genus from Nepal (Gastropoda, Pulmonata, Cerastidae). ZooKeys 175: 19-26. https:// doi.org/10.3897/zookeys.175.2755

CoCKerell T. D. A. 1912. The genera Cryptogirasia and Cryptosoma. The Nautilus 26: 70.

Cox J. C. 1868. On some new species of Australian land shells. Proceedings of the Zoological Society of London 1867: 722-726.

Crosse H., FISCHER P. 1863. Note sur la faune malacologique de Cochinchine, comprenant la description des espèces nouvelles ou peu connues. Journal de Conchyliologie 11: 343-379.

DAUTZENBERG P. 1887. Description d'espèces nouvelles de coquilles du Tonkin et observations dur quelques autres mollusques de la même région. Journal de Conchyliologie 35: 1-15.

DAUTZENBERG P., FisCHER H. 1905. Liste des mollusques récoltés par $\mathrm{M}$. le Capitaine de Frégate Blaise au Tonkin et déscription d'espèces nouvelles. Journal de Conchyliologie 53: 85-234.

DAUTZENBERG P., FISCHER H. 1908. Liste des mollusques récoltés par $\mathrm{M}$. Mansuy en Indo-Chine et description d'espèces nouvelles. II. Journal de Conchyliologie 56: 169-217.

DAUTZENBERG P., D’HAMONVILLE L. 1887. Description d'espèces nouvelles du Tonkin et observations sur quelques autres molluscque de la même région. Journal de Conchyliologie 35: 213-225.

DenZer W., MANThey U., Wagner P., BÖHME W. 2016. A critical review of Hoser's writings on Draconinae, Amphibolurinae, Laudakia and Uromastycinae (Squamata: Agamidae). Bonn Zoological Bulletin 64: 117-138.

Do D. S., Do V. N. 2014. The landsnail family Subulinidae (Gastropoda: Pulmonata) from Son La, Vietnam, with description of two new species. Tap Chi Sinh Hoc 36: 451-459. 
DuBoIS A. 2008. A partial but radical solution to the problem of nomenclatural taxonomic inflation and synonymy load. Biological Journal of the Linnean Society 93: 857-863. https://doi.org/10.1111/j.10958312.2007.00900.x

Egorov R. V. 2009. The genus Cyclotus Guilding in Swainson, 1840: Systematics and nomenclature. Conchylia 40: 16-22.

EGOROV R. V. 2013. Treasure of Russian shells. Supplement 3. A review of the genera of the terrestrial pectinibranch molluscs (synopsis mainly based on published data). Part III. Littoriniformes: Liareidae, Pupinidae, Diplommatinidae, Alycaeidae, Cochlostomidae. Roman Egorov, Moscow.

EMBERTON K. C. 1995. Cryptic, genetically extremely divergent, polytypic, convergent, and polymorphic taxa in Madagascan Tropidophora (Gastropoda: Pomatiasidae). Biological Journal of the Linnean Society 55: 183-208. https://doi.org/10.1111/j.1095-8312.1995.tb01059.x

EVEnHuIS N. L. 2008. The "Mihi itch" - a brief history. Zootaxa 1890: 59-68. https://doi.org/10.11646/zootaxa.1890.1.3

FÉRUSSAC A. E. J. P. F. D’AUdEBARD DE 1819-1832. Histoire naturelle générale et particulière des mollusques terrestres et fluviatiles tant des espèces que l'on trouve aujourd'hui vivantes, que des dépouilles fossiles de celles qui n'existent plus; classés d'après les caractères essentiels que présentent ces animaux et leurs coquilles. J.-B. Baillière, Paris.

FISCHER P., CROSSE H. 1872-1902. Etudes sur les Mollusques terrestres et fluviatiles du Mexique et du Guatemala. Mission scientifique au Mexique et dans l'Amérique Centrale. Recherches zoologiques, Partie 7. Imprimerie Nationale, Paris.

FisCher-PietTe E., BlanC C. P., BLANC F., SAlVAT F. 1993. Gastéropodes terrestres prosobranches. Faune de Madagascar 80: 1-281.

Fischer-PietTe E., BlanC C. P., Blanc F., SAlvat F. 1994 Gastéropodes terrestres pulmonés (excl. Veronicellidae et g. Elisolimax). Faune de Madagascar 83: 1-551.

FORCART L. 1946. Indoartemon subgen. nov. for Odontartemon Kobelt, 1905 (non Pfeiffer, 1856); Streptaxidae. Journal of Conchology 22: 215.

FRUHSTORFER H. 1905. Ein neuer Amphidromus Nachrichtsblatt der Deutschen Malakozoologischen Gesellschaft 37: 83-84.

FULTON H. 1896. A list of the species of Amphidromus Albers, with critical notes and descriptions of some hitherto undescribed species and varieties. The Annals and Magazine of Natural History, series 6, 17: 66-94.

GARNETT S. T., CHRISTIDIS L. 2017. Taxonomy anarchy hampers conservation. Nature 546: 25-27. https://doi. org/10.1038/546025a

GERET P. 1912. Description d'un nouvel Amphidromus. Journal de Conchyliologie 60: 55-56.

GODWIN-AUSTEN H. H. 1882-1920. Land and freshwater Mollusca of India, including South Arabia, Baluchistan, Afghanistan, Kashmir, Nepal, Burmah, Pegu, Tenasserim, Malay Peninsula, Ceylon, and other islands of the
Indian Ocean. Supplementary to Messrs. Theobald and Hanley's Conchologia Indica. Taylor \& Francis, London.

GODWIN-AUSTEN H. H. 1891. On a collection of land shells made in Borneo by Mr. Everett, with descriptions of supposed new species. Part II. Zonitidae and Helicinidae. Proceedings of the Zoological Society of London 1891: $22-47$.

Gould A. A. 1856. Descriptions of shells. Proceedings of Boston Society of Natural History 6: 11-16.

GRAY J. E. 1825. A list and description of some species of shells not taken notice of by Lamarck. Annals of Philosophy New Series 9: 134-140, 407-415.

GRAY J. E. 1847. A list of genera of Recent Mollusca, their synonyms and types. Proceedings of the Zoological Society of London 15: 129-219.

GRAY J. E. 1855. Catalogue of Pulmonata or air-breathing Mollusca in the collection of the British Museum, Part I. Taylor \& Francis, London.

GRAY J. E. 1860. On the arrangement of the land pulmoniferous Mollusca into families. The Annals and Magazine of Natural History, series 3, 6: 267-269.

GREDLER V. 1887. Zur Conchylien-Fauna von China. IX. Stück. Malakozoologische Blätter 9 (N. F.): 1-20. https://biodiversitylibrary.org/page/35483047

Grego J., LuONG H. V., PhAM S. V., SZEKeres M. 2014. Vietnamese Clausiliidae (Gastropoda: Pulmonata): new taxa and novel distribution data. Journal of Conchology 41: 749-757.

GUDE G. K. 1911. Note on some preoccupied generic names and proposed new genera of the family Zonitidae. Proceedings of the Malacological Society of London 9: 269-273.

GUDE G. K. 1913. Definitions of further new genera of Zonitidae. Proceedings of the Malacological Society of London 10: 389-391.

GudE G. K., WoOdWARD B. B. 1921. On Helicella, Férussac. Proceedings of the Malacological Society of London 14: 174-190.

HAAS F. 1934. Neue Landschnecken des SenckenbergMuseums. Senckenbergiana 16: 94-98.

HAAS F. 1935. Kleine Bemerkungen, IV. Zoologischer Anzeiger 108: 45-47.

HABE T. 1965. Operculated land molluscs from South-East Asia. In: Nature and Life in Southeast Asia. 4. Fauna and Flora Research Society, Kyoto, Japan, pp. 111-128.

HANIEL C. B. 1921. Variationsstudie an timoresischen Amphidromusarten. Zeitschrift für inductive Abstammungs- und Verebungslehre 25: 1-88.

HAINES W. A. 1855. Descriptions of four new species of terrestrial shells from Siam. Annals of the Lyceum of Natural History of New York 6: 157-158.

Hemmen J., HeMmen C. 2001. Aktualisierte Liste der terrestrischen Gastropoden Thailands. Schriften zur Malakozoologie - aus dem Haus der Natur Cismar 18: 35-70.

Huber F. 2015. Amphidromus thachi, a new species (Gastropoda: Camaenidae) from Vietnam. Gloria Maris 54: 29-31. 
HYMAN I. T., DE LA IGLESIA LAMBORENA I., KÖHLER F. 2017. Molecular phylogenetics and systematic revision of the south-eastern Australian Helicarionidae (Gastropoda, Stylommatophora). Contributions to Zoology 86: 5195. https://doi.org/10.1163/18759866-08601004

INKHAVILAY K., SIRIBOON T., SUTCHARIT C., ROWSON B., PANHA S. 2016. The first revision of the carnivorous land snail family Streptaxidae in Laos, with description of three new species (Pulmonata, Stylommatophora, Streptaxidae). ZooKeys 589: 23-53. https://doi. org/10.3897/zookeys.589.7933

INKHAVILAY K., SUTCHARIT C., BANTAOWONG U., CHANABUN R., SIRIWUT W., SRISONCHAI R., PHOLYOTHA A., JIRAPATRASILP P., PANHA S. 2019. Annotated checklist of the terrestrial molluscs from Laos (Mollusca, Gastropoda). ZooKeys 834: 1-166. https://doi. org/10.3897/zookeys.834.28800

INKHAVILAY K., SUTCHARIT C., PANHA S. 2017. Taxonomic review of the tree snail genus Amphidromus Albers, 1850 (Pulmonata: Camaenidae) in Laos, with the description of two new species. European Journal of Taxonomy 330: 1-40. https://doi.org/10.5852/ejt.2017.330

IREDALE T. 1938. A basic list of the land Mollusca of Australia. Part III. The Australian Zoologist 9: 83-124.

IREDALE T. 1941. Guide to the land shells of New South Wales. Part III. Australian Naturalist 11: 1-8.

Kaiser H., Crother B. L., Kelly C. M. R., Luiselli L., O'SheA M., OTA H., PAsSOS P., SCHLEIP W. D., WÜSTER W. 2013. Best practices: in the 21st century, taxonomic decisions in herpetology are acceptable only when supported by a body of evidence and published via peer-review. Herpetological Review 44: 8-23.

Kobelt W. 1899-1902. Die Familie Buliminidae. In: KÜSTER H. C., Kobelt W. (eds). Systematisches ConchylienCabinet von Martini und Chemnitz (vol. 1, 13(2)). Bauer \& Raspe, Nürnberg, pp. 397-1051.

KoBelt W. 1902. Das Tierreich. Eine Zusammenstellung und Kennzeichnung der rezenten Tierformen. In Verbindung mit der Deutschen Zoologischen Gesellschaft herausgegeben von der Königlich Preussischen Akademie der Wissenschaften zu Berlin. Mollusca: Cyclophoridae. R. Friedländer und Sohn, Berlin.

KobelT W. 1905-1906. Die Raublungenschnecken (Agnatha). Abtheilung 2, Streptaxidae und Daudebardiidae. In: MARTINI F. H. W. VON, CHEMNITZ J. H. (eds). Systematisches Conchylien-Cabinet, ed. 2. Bd. 1, Abt. 12B, Theil 2. Bauer \& Raspe, Nürnberg, pp. 1-211 [pp. 1-96, pls 42-59 (1905); 97-211, pls 60-71 (1906)].

KÖHLER F., CRISCIONE F., BURGHARDT I., KESSNER V. 2016. The Enidae of Timor (Stylommatophora: Orthurethra). Molluscan Research 37: 8-16 (2017). https://doi.org/1 0.1080/13235818.2016.1200959

KongiM B., Sutcharit C., NAggS F., PANHA S. 2013. Taxonomic revision of the elephant pupinid snail genus Pollicaria Gould, 1856 (Prosobranchia, Pupinidae). ZooKeys 287: 19-40. https://doi.org/10.3897/zookeys.287.4617

LAIDLAW F. F. 1963. Notes on the genus Dyakia, with a list of species. Journal of Conchology 25: 137-151.
LAIDLAW F. F., SOLEM A. 1961. The land snail genus Amphidromus. A synoptic catalogue. Fieldiana: Zoology 41: 503-677.

LiNDHOLM W. A. 1924. A revised systematic list of the genera of the Clausiliidae, recent and fossil, with their subdivisions, synonymy, and types. Proceedings of the Malacological Society of London 16: 53-80.

MAASSEN W. J. M. 2001. A preliminary checklist of the non-marine molluscs of West-Malaysia: "a hand list". De Kreukel, Extra Editie 2001: 1-155.

MAASSEN W. J. M. 2006. Four new species of terrestrial gastropods from Tonkin, North Vietnam (Gastropoda, Diplommatinidae, Strobilopsidae and Ariophantidae). Basteria 70: 13-18.

MAASSEN W. J. M. 2016. Descriptions of two new carnivorous snail species from Thailand (Pulmonata: Streptaxidae, Diapheridae). Basteria 80: 139-142.

MABILLE J. 1887. Molluscorum Tonkinorum Diagnoses. A. Masson, Meulan.

MABILLE J. 1889. Contributions a la faune macalogique [sic!] du Tonkin. Masson, A. Meulan.

MinATO H., CHEN D.-N. 1984. A new clausiliid genus Grandinenia for Steatonenia mirifica Chen \& Gao, 1982 (Gastropoda: Pulmonata). Venus (Japanese Journal of Malacology) 43: 301-304.

Minton R. L., HaRris P. M., NORTH E., TU D. V. 2017. Diversity and taxonomy of Vietnamese Pollicaria (Gastropoda, Pupinidae). Zoosystematics and Evolution 93: 95-104. https://doi.org/10.3897/zse.93.10794

MÖllENDORFF O. F. VON 1890. Die LandschneckenFauna der Insel Cebu. Bericht der Senckenbergischen Naturforschenden Gesellschaft in Frankfurt am Main (1889-90): 189-292.

MÖLLENDORFF O. F. VON 1894. On a collection of land-shells from the Samui Islands, Gulf of Siam. Proceedings of the Zoological Society of London 1894: 146-156. https:// www.biodiversitylibrary.org/item/97157\#page/212/ mode/lup

MÖllENDORFF O. F. VON 1898. Die Binnenmollusken Annams. Nachrichtsblatt der Deutschen Malakozoologischen Gesellschaft 30(5/6): 65-85.

MÖLlENDORFF O. F. VON 1900a. Zur BinnenmolluskenFauna von Annams III. Nachrichtsblatt der Deutschen Malakozoologischen Gesellschaft 32: 117-121; 129-139.

MÖLlENDORFF O. F. VON 1900b. Zwei neue Amphidromus aus Annam. Nachrichtsblatt der Deutschen Malakozoologischen Gesellschaft 32: 22-24.

MÖlLENDORFF O. F. VON 1901. Zur BinnenmolluskenFauna von Annam IV. Nachrichtsblatt der Deutschen Malakozoologischen Gesellschaft 33: 45-50.

MÖLLENDORFF O. F. VON 1902. Binnenmollusken aus Hinterindien. Nachrichtsblatt der Deutschen Malakozoologischen Gesellschaft 34: 153-162.

MollusCABASE 2019. Amphidromus Albers, 1850. Accessed at: http://www.molluscabase.org/aphia.php?p=taxdetails\&id=818112 (accessed 26 April 2019). 
MONTFORT P. 1808-1810. Conchyliologie systématique et classification méthodique des coquilles.Vol. 1: pp. lxxxvii +409 [1808]. Vol. 2: pp. $676+16$, Schoell, Paris.

Moore M., Jameson M. E., PAUCAR-CABrera A. 2014. Taxonomic vandalism is an emerging problem for biodiversity science: A case study in the Rutelini (Coleoptera: Scarabaeidae: Rutelinae). Entomological Society of America 62nd Annual Meeting, Portland, Oregon, November 16-19, 2014.

MÖRCH O. A. L. 1876. Révision des mollusques terrestres des îsles Nicobar. Journal de Conchyliologie 24: 353-367.

Morelet A. 1862. Diagnoses testarum Indo-Sinarum. Revue et Magasin de Zoologie pure et appliquée 2e série, 14: 477-481.

MORELET A. 1875. Series Conchyliologiques, comprenant Lénumération de mollusques terrestres et fluviatiles, recueillis pendant le cours de différents voyages, ainsi que la description, de plusieurs espèces nouvelles. IV. 4e livraison Indo Chine. F. Savy, Paris, pp. 227-377. https://doi.org/10.5962/bhl.title.11458

MORLET L. 1883. Description d'espèces nouvelles de coquilles recueillies par M. Pavie au Cambodge. Journal de Conchyliologie 23: 104-110.

MORLET L. 1885. Descriptions despèces nouvelles de coquilles recueillies par M. Pavie, au Cambodge. Journal de Conchyliologie 32 [1884]: 386-403.

MORLET L. 1886. Diagnoses molluscorum novorum Cambodgiae. Journal de Conchyliologie 34: 74-75.

MORLET L. 1891. Diagnoses molluscorum novorum, in Indochinâ collectorum. Journal de Conchyliologie 39: 25-28.

Mousson A. 1849a. Über die Land- und Süsswassermollusken von Java. Mittheilungen der Naturforschenden Gesellschaft in Zürich 1: 264-273.

Mousson A. 1849b. Die Land- und Süsswasser- Mollusken von Java. Friedrich Schulthess, Zurich. iv + 126 pp., 22 pls.

NANTARAT N., Sutcharit C., TONGKerd P., Ablett J., NAGGS F., PANHA S. 2014. An annotated catalogue of type specimens of the land snail genus Cyclophorus Montfort, 1810 (Caenogastropoda, Cyclophoridae) in the Natural History Museum, London. ZooKeys 411: 1-56. https://doi.org/10.3897/zookeys.411.7258

NANTARAT N., Sutcharit C., TONGKerd P., WADE C. W., NAGGS F., PANHA S. 2019. Phylogenetics and species delimitations of the operculated land snail Cyclophorus volvulus (Gastropoda: Cyclophoridae) reveal cryptic diversity and new species in Thailand. Scientific Reports 9: 7041. https://doi.org/10.1038/s41598-019-43382-5

NORDSIECK H. 2002. Revision of the Garnieriinae (Gastropoda: Stylommatophora: Clausiliidae), with descriptions of new taxa. Stuttgarter Beiträge zur Naturkunde, Serie A (Biologie) 640: 1-23.

PÁlL-Gergely B. 2019. Correction of two homonyms and an original spelling of Thach. Ruthenica 29: 75-76 [2018].

PÁll-Gergely B., Grego J. 2019. Notes on Pseudopomatias Möllendorff, 1885 and Vargapupa Páll-Gergely, 2015
(Gastropoda: Caenogastropoda: Pupinidae). Raffles Bulletin of Zoology 67: 587-594.

PÁll-Gergely B., HunYADI A. 2018. Ariophanta huberi Thach, 2018 is not a pulmonate, but a juvenile Pollicaria rochebruni (Mabille, 1887) (Gastropoda: Cyclophoroidea: Pupinidae). Folia Malacologica 26: 267-269. https:// doi.org/10.12657/folmal.026.025

PÁlL-Gergely B., NeuberT E. 2019. New insights in Trichochloritis Pilsbry, 1891 and its relatives (Gastropoda: Pulmonata: Camaenidae). ZooKeys 865: 137-154. https://doi.org/10.3897/zookeys.865.36296

PÁLl-GERGELY B., SZEKERES M. 2017. New and little-known Clausiliidae (Gastropoda: Pulmonata) from Laos and southern Vietnam. Journal of Conchology 42: 507-521.

PÁll-Gergely B., Fehér Z., Hunyadi A., Asami T. 2015. Revision of the genus Pseudopomatias and its relatives (Gastropoda: Cyclophoroidea: Pupinidae). Zootaxa 3937: 1-49. https://doi.org/10.11646/zootaxa.3937.1.1

PÁll-Gergely B., NAggs F., Asami T. 2016. Novel shell device for gas exchange in an operculated land snail. Biology Letters 12: 20160151. https://doi.org/10.1098/ rsbl.2016.0151

PANHA S., PATAMAKANTHIN S. 2001. A new Alycaeus species from southern Thailand (Prosobranchia: Cyclophoracea: Cyclophoridae). Of Sea and Shore 23: 189-190.

PEARSON J. T. 1833. Note on the genus Spiraculum. Journal of the Asiatic Society of Bengal 2: 590-592.

PFEIFFER L. 1846. Descriptions of thirty-six new species of Helix, belonging to the collection of H. Cuming, Esq. Proceedings of the Zoological Society of London [1845]: 126-133.

PFEIFFER L. 1847. Ueber die Eintheilung der Cyclostomaceen. Zeitschrift für Malakozoologie 4: 45-48, 52-59.

PFEIFFER L. 1853. Catalogue of Phaneropneumona or Terrestrial Operculated Mollusca in the Collection of the British Museum. Woodfall \& Kinder, London.

PFEIFFER L. 1856. Versuch einer Anordnung der Heliceen nach natürlichen Gruppen. Malakozoologische Blätter 2: 112-185.

PFEIFFER L. 1860. Description of thirty-six new species of land shells from Mr. H. Cuming's collection. Proceedings of the Zoological Society of London 1860: 133-141.

PFEIFFER L. 1861. Descriptions of new land-shells, in the collection of $\mathrm{H}$. Cuming, Esq. Proceedings of the Zoological Society of London 29: 190-196.

PFEIFFER L. 1863. Descriptions of thirty-six new land shells, from the collection of $\mathrm{H}$. Cuming, Esq. Proceedings of the Zoological Society of London 30: 268-278 [1862].

PILSBRY H. A. 1890-1891. Manual of conchology, structural and systematic, with illustrations of the species, Second series: Pulmonata. Vol. VI. Helicidae. Academy of Natural Sciences, Philadelphia.

PILSBRY H. A. 1893-1895. Manual of conchology, structural and systematic, with illustrations of the species. Second series: Pulmonata. Vol. VIII, Helicidae, Vol. 6. Conchological Section, Academy of Natural Sciences, Philadelphia. 
PILSBRY H. A. 1900a. Manual of conchology, structural and systematic, with illustrations of the species. Second series, Volume 13. Academy of Natural Sciences, Philadelphia.

PILsBRY H. A. 1900b. Notices of some new Japanese mollusks. The Nautilus 14: 11-12.

Pilsbry H. A. 1906-1907. Manual of conchology, (2) 18. Achatinidae: Stenogyrinae and Coeliaxinae. Academy of Natural Sciences, Philadelphia.

Raheem D. C., Taylor H., Ablett J., Preece R. C., ARAVIND N. A., NAGGS F. 2014. A systematic revision of the land snails of the Western Ghats of India. Tropical Natural History Supplement 4(1-13): 1-285.

REEVE L. 1860. On two new species of shells from Cambojia. The Annals and Magazine of Natural History, series 3, 6 : 203-204.

RENSCH I. 1934. Systematische und tiergeographische Untersuchungen über die Landschneckenfauna des Bismarck-Archipels I. Archiv für Naturgeschichte, Neue Folgen 3: 445-488.

SCHEPMAN M. M. 1892. Land- and freshwater shells collected by Dr. H. Ten Kate in Soemba, Timor, and other East-Indian Islands. Notes from the Leyden Museum 14: 145-160.

SCHILEYKO A. A. 1999. Treatise on recent terrestrial pulmonate molluscs, Part 4: Draparnaudiidae, Caryodidae, Macrocyclidae, Acavidae, Clavatoridae, Dorcasiidae, Sculptariidae, Corillidae, Plectopylidae, Megalobulimulidae, Strophocheilidae, Cerionidae, Achatinidae, Subulinidae, Glessulidae, Micractaeonidae, Ferrussaciidae. Ruthenica, Supplement 2: 435-564.

SCHILEYKO A. A. 2000. Treatise on recent terrestrial pulmonate molluscs, Part 6: Rhytididae, Chlamydephoridae, Systrophiidae, Haplotrematidae, Streptaxidae, Spiraxidae, Oleacinidae, Testacellidae. Ruthenica, Supplement 2: 731-880.

SCHILEYKO A. A. 2002. Treatise on recent terrestrial pulmonate molluscs, Part 9: Helicarionidae, Gymnarionidae, Rhysotinidae, Ariophantidae. Ruthenica, Supplement 2: 1167-1307.

SCHILEYKO A. A. 2003. Treatise on recent terrestrial pulmonate molluscs, Part 11: Trigonochlamydidae, Papillodermidae, Vitrinidae, Limacidae, Bielziidae, Agriolimacidae, Boettgerillidae, Camaenidae. Ruthenica, Supplement 2: 1467-1626.

SCHILEYKO A. A. 2011. Check-list of land pulmonate molluscs of Vietnam (Gastropoda: Stylommatophora). Ruthenica 21: 1-68.

Schutze M. K., Bourtzis K., CAmeron S. L., Clarke A. R., DE MEYer M., HeE A. K. W., HeNDrichS J., KROSCH M. N., MWATAWALA M. 2017. Integrative taxonomy versus taxonomic authority without peer review: the case of the Oriental fruit fly, Bactrocera dorsalis (Tephritidae). Systematic Entomology 42: 609-620. https://doi. org/10.1111/syen. 12250

SiribOON T., SuTCHARIT C., NAGGS F., RowsON B., PANHA S. 2014a. Revision of the carnivorous snail genus Indoartemon Forcart, 1946 and a new genus Carinartemis from Thailand (Pulmonata: Streptaxidae). Raffles Bulletin of Zoology 62: 161-174.

SiRIBOON T., SUTCHARIT C., NAGGS F., ROWSON B., PANHA S. 2014b. Revision of the carnivorous snail genus Discartemon Pfeiffer, 1856, with description of twelve new species (Pulmonata, Streptaxidae). ZooKeys 401: 45-107. https://doi.org/10.3897/zookeys.401.7075

SMITH E. A. 1896. Notes on some land-shells from Vanbu, Tonkin, with descriptions of two new species. The Annals and Magazine of Natural History, series 6, 17: 128-130.

SOLEM A. 1965. Land snails of the genus Amphidromus from Thailand (Mollusca: Pulmonata: Camaenidae). Proceedings of the United States National Museum 117: 615-628.

SOULEYET M. 1841. Description de deux espèces nouvelles des genres Hélice et Cyclostome. Revue Zoologique par la Société Cuvierrenne 4: 347.

StANisic J., SheA M., POTTER D., GRIFFITHS O. 2010. Australian land snails. Volume 1. A field guide to Eastern Australian species. Queensland Museum, Brisbane.

SutCharit C., ABletT J. D., PANHA S. 2019a. An annotated type catalogue of seven genera of operculate land snails (Caenogastropoda, Cyclophoridae) in the Natural History Museum, London. ZooKeys 842: 1-65. https:// doi.org/10.3897/zookeys.842.29243

SUTCHARIT C., ABLETT J., TONGKERD P., NAGGS F., PANHA S. 2015. Illustrated type catalogue of Amphidromus Albers, 1850 in the Natural History Museum, London, and descriptions of two new species. ZooKeys 492: 49-105. https://doi.org/10.3897/zookeys.492.8641

SutCharit C., BACKeljaU T., PANHA S. 2019b. Redescription of the type species of the genera Ganesella Blanford, 1863 and Globotrochus Haas, 1935; with description of a new Ganesella species from Thailand (Eupulmonata, Camaenidae). ZooKeys 870: 51-76. https://doi.org/10.3897/zookeys.870.36970

SUTCHARIT C., LIN A., CHANABUN R., SRISONCHAI R., PANHA S. (in press). Two new species of the carnivorous snails genus Discartemon Pfeiffer, 1856 (Eupulmonata: Steptaxidae) from Thailand and Myanmar with taxonomic review of the genus. Raffles Bulletin of Zoology.

SUTCHARIT C., PANHA S. 2006. Taxonomic review of the tree snail Amphidromus Albers, 1850 (Pulmonata: Camaenidae) in Thailand and adjacent areas: subgenus Amphidromus. Journal of Molluscan Studies 72: 1-30. https://doi.org/10.1093/mollus/eyi044

SUTCHARIT C., PANHA S. 2010. Taxonomic re-evaluation of Chloritis bifoveata (Benson, 1860) and C. diplochone Mollendorff, 1898 (Pulmonata: Camaenidae). Journal of Conchology 40: 277-285.

SUTCHARIT C., TONGKERD P., SHAU-HWAI A. T., PANHA S. 2012. Taxonomic revision of Dyakia janus from peninsular Malaysia (Pulmonata: Dyakiidae), with notes on other sinistrally coiled helicarionids. Raffles Bulletin of Zoology 60: 279-287.

SWAINSON W. 1840. A treatise on malacology or the natural classification of shells and shellfish. Longman, Brown, Green \& Longman, London. 
TAPPARONE-CANEFRI C. 1874. Zoologia del viaggio intorno al globo della regia fregata Magenta durante gli anni 1865-68. Malacologia (Gasteropodi, Acefali e Brachiopodi). Torino.

THACH N. N. 2014. A new Amphidromus (Gastropoda: Camaenidae) from Vietnam. Gloria Maris 53: 38-42.

THACH N. N. 2015a. Amphidromus setzeri, a new species (Gastropoda: Camaenidae) from Vietnam. Gloria Maris 54: 56-58.

THACH N. N. 2015b. Pterocyclos huberi, a new species from Vietnam (Gastropoda: Caenogastropoda: Cyclophoridae). Novapex 16: 59-61.

THACH N. N. 2015c. Bertia setzeri, a new species of land snail from Vietnam (Gastropoda: Stylommatophora: Dyakiidae). The Festivus 47: 240-242.

THACH N. N. 2016a. Vietnamese new molluscs. Seashells Landsnails - Cephalopods. 48HrBooks Company, Akron (Ohio, USA).

THACH N. N. 2016b. Cyclophorus stevenabbasorum (Gastropoda: Cyclophoridae), a new species from Indonesia. Gloria Maris 54: 118-120.

THACH N. N. 2016c. Amphidromus jeffabbasorum, a new species (Gastropoda: Camaenidae) from Indonesia Xenophora Taxonomy 13: 3-5.

THACH N. N. 2016d. Camaena abbasi, a new species (Gastropoda: Camaenidae) from Indonesia. The Festivus 48: 109-112.

THACH N. N. 2016e. Camaena chuongi, a new species (Gastropda: Camaenidae) from Vietnam. The Festivus 48: 253-256.

THACH N. N. 2016f. Camaena onae, a new species (Gastropoda: Camaenidae) from Vietnam. Gloria Maris 55: 17-20.

THACH N. N. 2016g. Obba louiseae, a new species (Gastropoda: Camaenidae) from the Philippines. Xenophora Taxonomy 10: 3-5.

THACH N. N. 2016h. Papuina abbasi, a new species (Gastropoda: Pupinidae) from Indonesia. Malacologia Mostra Mondiale 93: 23-25.

THACH N. N. 2017a. New shells of Southeast Asia. Sea shells \& Land snails. 48HrBooks Company, Akron (Ohio, USA).

THACH N. N. 2017b. Four new species of Amphidromus Albers, 1850 (Gastropoda: Camaenidae) from Vietnam. Gloria Maris 56: 35-39.

THACH N. N. 2017c. Three new species of Amphidromus Albers, 1850 (Gastropoda: Camaenidae) from Vietnam, and presentation of Conus (Rhizoconus) paulkersteni, nom nov. pro Conus kersteni Thach, 2017 non Tenorio, Afonso \& Rolán, 2008. The Festivus 49: 296-300.

THACH N. N. 2017d. Amphidromus calvinabbasi, a new species (Gastropoda: Camaenidae) from Indonesia. Xenophora Taxonomy 17: 41-43.

THACH N. N. 2017e. Amphidromus chrisabbasi, a new species (Gastropoda: Camaenidae) from Indonesia. The Festivus 49: 206-209.

THACH N. N. 2017f. Four new species and subspecies of Amphidromus Albers, 1850 (Gastropda [sic!]:
Camaenidae) from Indonesia and Vietnam. Malacologia Mostra Mondiale 97: 34-37.

THACH N. N. 2018a. New shells of South Asia. Seashellslandsnails-freshwater shells. 3 new genera, 132 new species \& subspecies. 48HRBooks Company, Akron (Ohio, USA).

THACH N. N. 2018b. Four new species and subspecies of Amphidromus Albers, 1850 (Gastropoda: Camaenidae) from Vietnam, Laos and Indonesia. Conchylia 48: 33-40.

THACH N. N. 2018c. Leptopoma melanostoma janetabbasae, a new subspecies (Gastropoda: Cyclophoridae) from Indonesia, and correction of errata in "New Shells of South Asia". The Festivus 50: 264-267.

THACH N. N. 2019a. Amphidromus atricallosus vovanae, a new subspecies of Amphidromus from Vietnam (Mollusca: Gastropoda: Camaenidae). Gloria Maris 57: 84-87.

THACH N. N. 2019b. Two new species of Amphidromus (Gastropoda: Camaenidae) from Cambodia \& Laos. The Festivus 51: 37-42.

THACH N. N. 2019c. Two new species of Amphidromus (Gastropoda: Camaenidae) from Vietnam. The Festivus 51: 103-108.

THACH N. N. 2019d. Amphidromus siongkiati and Amphidromus bramvanderbijli, two new species of Amphidromus (Mollusca: Gastropoda: Camaenidae) from Vietnam and correction of errata in "New Shells of South Asia". Gloria Maris 58: 17-21.

THACH N. N. 2019e. Two new subspecies of Amphidromus from Indonesia (Mollusca: Gastropoda: Camaenidae). The Festivus 51: 231-236.

THACH N. N. 2019f. Amphidromus huynhanhi, a new species (Gastropoda: Camaenidae) from Laos. Conchylia 50: $11-14$.

THACH N. N. 2019g. A new species of Amphidromus (Mollusca: Gastropoda: Camaenidae) from Vietnam, and a replacement name for Amphidromus berschaueri mingmini Thach, 2019. The Festivus 51: 293-296.

THACH N. N. 2019h. Two new species of Amphidromus from Vietnam (Gastropoda: Camaenidae). Visaya 5: 33-38.

THACH N. N., ABBAS J. 2017a. Amphidromus lucsegersi, a new species (Gastropoda: Camaenidae) from Indonesia. Gloria Maris 55: 52-54.

THACH N. N., ABBAS J. 2017b. Amphidromus stevehubrechti, a new species (Gastropoda: Camaenidae) from Indonesia. Gloria Maris 55: 119-121.

THACH N. N., HuBER F. 2014. A new Amphidromus (Gastropoda: Camaenidae) from Vietnam. Basteria 78: 35-37.

THACH N. N., HubER F. 2015. New species of Vietnam landsnails. American Conchologist 43: 26-27.

THACH N. N., HUBER F. 2017. A new species of Amphidromus Albers, 1850 (Gastropoda: Camaenidae) from Vietnam. Gloria Maris 55: 123-125.

Thomson S., Pyle R. L., Ahyong S. T., Alonso-Zarazaga M., Ammirati J., ARAYA J. F., Ascher J. S., Audisio T. L., AZEVEDO-SANTOS V. M., BAILlY N., BAKER W. J., BALKE M., Barclay M. V. L., BarRetT R. L., Benine R. C., BICKERSTAFF J. R. M., BOUCHARD P., BOUR R., BOURGOIN 
T., BOYKo C. B., BREURE A. S. H., Brothers D. J., BYNG J. W., CAMPBEll D., CERÍACO L. M. P., CERNÁK I., CERRETTI P., Chang C. H., Cho S., Copus J. M., Costello M. J., CSEH A., CSuzdi C., CulHam A., D’Elía G., D’UdeKeM D'ACOZ C., DANeliYa M. E., DEKKer R., DiCKINSON E. C., DICKINSON T. A., VAN DIJK P. P., DIJKSTRA K. B., DIMA B., DMitRiEV D. A., DuistermaAT L., DUMBACHER J. P., EISERHARDT W. L., EKREM T., EVENHUIS N. L., FAILlE A., FERnÁNDEZ-TrianA J. L., FIESLER E., Fishbein M., Fordham B. G., Freitas A. V. L., Friol N. R., FritZ U., FrøsleV T., FunK V. A., Gaimari S. D., Garbino G. S. T., GarrafFoni A. R. S., GeMl J., Gill A. C., GraY A., Grazziotin F. G., GreEnSLAde P., GutiÉrReZ E. E., Harvey M. S., Hazevoet C. J., He K., He X., Helfer S., Helgen K. M., van Heteren A. H., Hita Garcia F., Holstein N., HoRVÁtH M. K., HOVENKAMP P. H., HWANG W. S., HyvÖNEN J., ISLAM M. B., IVERSON J. B., IVIE M. A., JAAFAR Z., JACKSON M. D., JAYAT J. P., JOHNSON N. F., KAISER H., KLITGÅRD B. B., KNAPP D. G., Kojima J. I., KÕLJalg U., KONTSCHÁN J., KRELl F. T., KRISAI-GREILHUBeR I., KULlandeR S., LATELla L., LATTKE J. E., LENCIONI V., LEWIS G. P., LHANO M. G., LUJAN N. K., LUKSENBURG J. A., MARIAUX J., MARINHOFilho J., Marshall C. J., Mate J. F., MCDONOUgh M. M., Michel E., Miranda V. F. O., MitroiU M. D., MOLINARI J., MONKS S., MOORE A. J., MORATELli R., MurÁNyi D., NAKANO T., NIKOLAEVA S., NOYES J., OHL M., Oleas N. H., OrRell T., PÁll-Gergely B., Pape T., PAPP V., PARENTI L. R., PATTERSON D., PAVlinOV I. Y., PINE R. H., POCZAI P., PRADO J., PRATHAPAN D., RABELER R. K., RANDAll J. E., RheindT F. E., RhODIN A. G. J., Rodríguez S. M., ROgers D. C., ROQUe F. O., Rowe K. C., Ruedas L. A., SAlazar-BraVo J., SAlVAdOR R. B., SANGSTER G., SARMIENTO C. E., SCHIGEL D. S., SCHMIDT S., SCHUElER F. W., SEgERS H., SNOW N., SOUZA-DiAS P. G. B., STAls R., STENROOS S., STONE R. D., STURM C. F., ŠTYS P., TETA P., THOMAS D. C., TIMM R. M., TINDALl B. J., TODD J. A., TRIEBEL D., VALDECASAS A. G., VizZINI A., VORONTSOVA M. S., DE VOS J. M., WAGNER P., WATLING L., WeAKLEY A., Welter-SChUltes F., WhitMORE D., WILDING N., WILL K., WILLIAMS J., WILSON K., WINSTON J. E., WÜster W., YANEGA D., YeATES D. K., ZAHER H.,
ZHANG G., ZHANG Z. Q., ZHOU H. Z. 2018. Taxonomy based on science is necessary for global conservation. PLoS Biology 16: e2005075. https://doi.org/10.1371/ journal.pbio. 2005075

TOMLIN J. R. LE B. 1948. New Malay land-shells. Proceedings of the Malacological Society of London 27: 224-225.

Troschel F. H. 1847. Ueber die Gattungen der Cyclostomiden. Zeitschrift für Malakozoologie 4: 42-45.

TUMPEESUWAN S., TUMPEESUWAN C. 2015. First record and description of a new species of the land snail genus Pearsonia Kobelt, 1902 (Cyclophoridae: Pterocyclinae) from Thailand, with a note on radula morphology. Raffles Bulletin of Zoology 63: 287-292.

WHEELER Q. 2014. Are reports of the death of taxonomy an exaggeration? New Phytologist 201: 370-371. https:// doi.org/10.1111/nph.12612

WU S.-P., HWANG C.-C., LIN Y.-S. 2008. Systematic revision of the arboreal snail Satsuma albida species complex (Mollusca: Camaenidae) with descriptions of 14 new species from Taiwan. Zoological Journal of the Linnean Society 154: 437-493. https://doi.org/10.1111/j.10963642.2008.00415.x

ZILCH A. 1953. Die Typen und Typoide des Natur-Museums Senckenberg, 10: Mollusca, Pleurodontidae (1). Archiv für Molluskenkunde 82: 131-140.

ZILCH A. 1956. Die Typen und Typoide des NaturMuseums Senckenberg, 18: Mollusca, Cyclophoridae, Cyclophorinae-Cyclophoreae (4). Archiv für Molluskenkunde 85: 171-196.

ZILCH A. 1961. Die Typen und Typoide des Natur-Museums Senckenberg, 24: Mollusca, Streptaxidae. Archiv für Molluskenkunde 90: 79-120.

ZILCH A. 1964. Die Typen und Typoide des Natur-Museums Senckenberg, 29: Mollusca, Camaenidae (3). Archiv für Molluskenkunde 93: 243-262.

Received: September 5th, 2019

Revised: December 12th, 2019 / February 2nd, 2020

Accepted: February 5th, 2020

Published on-line: March 13th, 2020

\section{APPENDIX 1}

Terrestrial species and subspecies described in the publications of NGUYEN NGOC THACH (some with co-authors FRANZ HubER, J. ABBAS and MiKLÓS SZEKERES). Abbreviations: MC - use of shell characters of minor importance, NC - new combination, LC - lack of comparison.

\begin{tabular}{llll}
\hline Species and subspecies & $\begin{array}{l}\text { Original generic } \\
\text { placement }\end{array}$ & References & Remarks \\
\hline abbasi & Ariophanta & THACH 2018a: 41 & LC \\
abbasi & Asperitas & THACH 2018a: 43 & no comment \\
abbasi & Bellardiella & THACH 2017a: 19 & no comment \\
abbasi & Camaena & THACH 2016d: 109 & NC \\
abbasi & Leptopoma & THACH 2017a: 15 & no comment \\
abbasi & Papuina & THACH 2016h: 23 & no comment \\
abbasi & Tylotoechus & THACH 2017a: 20 & no comment \\
abbasorum & Amphidromus & THACH 2017a: 35 & no comment \\
abbotthuberorum & Amphidromus & THACH 2017a: 35 & LC \\
\hline
\end{tabular}




\begin{tabular}{|c|c|c|c|}
\hline Species and subspecies & $\begin{array}{l}\text { Original generic } \\
\text { placement }\end{array}$ & References & Remarks \\
\hline abletti & Austenia & ТНАСН 2017a: 33 & no comment \\
\hline abletti & Chloritis & Thach et Huber in THACH 2018a: 68 & valid \\
\hline abletti & Rhiostoma & ТНАСН 2016а: 37 & LC \\
\hline andytani & Amphidromus & Thach et Abbas in THACH 2017a: 36 & LC \\
\hline anhdaoorum & Amphidromus & THACH 2017a: 36 & LC \\
\hline anhduongae & Haploptychius & ТНАСН 2017a: 31 & valid \\
\hline anhi & Camaena & ТНАСН 2017a: 49 & $\mathrm{LC}$ \\
\hline annhiae & Helixarion & Thach et Huber in THACH 2017a: 34 & NC \\
\hline anthonyabbotti & Amphidromus & Thach et Huber in THACH 2017a: 37 & LC \\
\hline arlingi & Amphidromus & THACH 2017f: 34 & $\mathrm{LC}$ \\
\hline arlingi & Pollicaria & THACH 2018a: 19 & no comment \\
\hline arlingi daklakensis & Amphidromus & ТНАСН 2017f: 36 & LC \\
\hline atricallosus vovanae & Amphidromus & ТНАСН 2019а: 84 & $\mathrm{LC}$ \\
\hline attapeuensis & Amphidromus & Thach et Huber in THACH 2017a: 37 & $\mathrm{LC}$ \\
\hline baerorum & Amphidromus & THACH 2017c: 297 & $\mathrm{LC}$ \\
\hline baoi & Amphidromus & THACH 2017a: 38 & LC \\
\hline baolocensis & Amphidromus & Thach et Huber in THACH 2016a: 62 & valid \\
\hline bernardfamyi & Amphidromus & THACH 2017a: 38 & no comment \\
\hline bernardfamyi kefaensis & Amphidromus & ТНАCH 2018a: 47 & no comment \\
\hline berschaueri mingmini & Amphidromus & THACH 2019e: 231 & no comment \\
\hline beschaueri & Amphidromus & THACH 2018a: 47 & $\mathrm{LC}$ \\
\hline bifoveata vinhensis & Chloritis & Thach et Huber in THACH 2018a: 68 & NC \\
\hline bimaensis liei & Asperitas & ТНACH 2018a: 44 & no comment \\
\hline binhgiaensis & Camaena & ТНАСН 2016a: 70 & $\mathrm{LC}$ \\
\hline binhphuocensis & Amphidromus & THACH 2019g: 293 & no comment \\
\hline bramvanderbijli & Amphidromus & THACH 2019d: 18 & no comment \\
\hline calvinabbasi & Amphidromus & ТНАCH 2017d: 41 & $\mathrm{MC}$ \\
\hline candoni & Helicella & ТНАСН 2018a: 72 & no comment \\
\hline cargilei & Amphidromus & Thach et Huber in THACH 2018a: 48 & $\mathrm{LC}$ \\
\hline chrisabbasi & Amphidromus & THACH 2017e: 206 & MC \\
\hline chrisabbasi roberti & Amphidromus & THACH 2018a: 49 & LC \\
\hline christabaerae & Amphidromus & THACH 2017c: 296 & $\mathrm{LC}$ \\
\hline christae & Rhiostoma & ТНАCH 2016а: 38 & LC \\
\hline chuongi & Camaena & THACH 2016e: 253 & valid \\
\hline contrarius rolfei & Amphidromus & THACH 2018a: 50 & no comment \\
\hline dambriensis & Amphidromus & Thach et Huber in ТHACH 2016a: 63 & LC \\
\hline daoae & Amphidromus & ТНАCH 2016а: 63 & $\mathrm{LC}$ \\
\hline daoae robertabbasi & Amphidromus & THACH 2017f: 36 & $\mathrm{LC}$ \\
\hline davidmonsecouri & Amphidromus & ТНАСН 2018a: 50 & LC \\
\hline delsaerdti & Amphidromus & ТНАCH 2016a: 64 & holotype is very weathered \\
\hline delsaerdti & Camaena & Thach et Huber in THACH 2018a: 67 & valid \\
\hline delsaerdti melanica & Camaena & Thach et Huber in THACH 2018a: 68 & valid \\
\hline diepae & Camaena & THACH 2017a: 50 & MC \\
\hline donchani & Amphidromus & THACH 2019b: 39 & no comment \\
\hline donghoiensis & Cyclophorus & Thach et Huber in THACH 2017a: 13 & see under Cyclophorus \\
\hline dongnaiensis & Amphidromus & THACH 2018a: 51 & MC \\
\hline ducae & Camaena & ТНАСН 2017a: 50 & no comment \\
\hline duyconi & Camaena & Thach et Huber in THACH 2017a: 51 & $\mathrm{LC}$ \\
\hline eboricolor & Amphidromus & ТНАСH 2018a: 51 & LC \\
\hline
\end{tabular}




\begin{tabular}{|c|c|c|c|}
\hline Species and subspecies & $\begin{array}{l}\text { Original generic } \\
\text { placement }\end{array}$ & References & Remarks \\
\hline franzhuberi & Amphidromus & THACH 2016a: 64 & LC \\
\hline franzhuberi & Camaena & THACH 2018a: 66 & LC \\
\hline franzhuberi & Cyclophorus & ТHACH 2017a: 14 & see under Cyclophorus \\
\hline franzhuberi & Hemiglypta & ТНАСН 2018a: 45 & no comment \\
\hline franzhuberi & Oospira & Szekeres et Thach in ТНАCH 2018a: 36 & $\mathrm{MC}$ \\
\hline franzhuberi & Papuina & THACH 2018a: 71 & no comment \\
\hline franzhuberi & Pearsonia & THACH 2017a: 15 & $\mathrm{MC}$ \\
\hline franzhuberi & Pseudobuliminus & ТHACH 2018a: 73 & valid \\
\hline franzhuberi & Pterocyclos & ТНACH 2017a: 16 & valid \\
\hline franzhuberi laosianus & Camaena & THACH 2018a: 66 & LC \\
\hline fraussenae & Amphidromus & Thach et Huber in THACH 2017a: 38 & LC \\
\hline frednaggsi & Amphidromus & Thach et Huber in THACH 2018a: 52 & LC, types all juveniles \\
\hline frednaggsi & Pupinella & Thach et Huber in THACH 2017a: 19 & valid \\
\hline friedae & Amphidromus & Thach et Huber in THACH 2016a: 65 & LC \\
\hline friedae & Pterocyclos & Thach et Huber in THACH 2016a: 36 & no comment \\
\hline friedahuberae & Amphidromus & Thach et Huber in THACH 2017a: 39 & valid \\
\hline gerberi & Amphidromus & Thach et Huber in THACH 2017a: 39 & $\mathrm{LC}$ \\
\hline gerberi bolovenensis & Amphidromus & Thach et Huber in THACH 2018a: 52 & no comment \\
\hline gittenbergeri & Amphidromus & Thach et Huber in THACH 2018a: 53 & LC \\
\hline goldbergi & Amphidromus & Thach et Huber in THACH 2018a: 53 & MC \\
\hline gregoi & Oospira & Szekeres et Thach in ТНАCH 2017a: 29 & valid \\
\hline gregoi & Perrottetia & THACH 2018a: 39 & see comment under $P$. gregoi \\
\hline grohi & Spiraculum & Thach et Huber in THACH 2018a: 18 & LC \\
\hline harryleei & Pseudobuliminus & THACH 2017a: 54 & MC \\
\hline harryleei & Spiraculum & Thach et Huber in THACH 2018a: 18 & LC \\
\hline hassi & Amphidromus & Thach et Huber in THACH 2018a: 54 & LC \\
\hline hassi ngoanmucensis & Amphidromus & Thach et Huber in THACH 2018a: 54 & LC \\
\hline heinrichhuberi & Amphidromus & Thach et Huber in THACH 2016a: 65 & LC \\
\hline herosae & Euplecta & Thach et Huber in THACH 2018a: 42 & LC \\
\hline herosae & Rhiostoma & Thach et Huber in THACH 2017a: 17 & valid \\
\hline hoabinhensis & Camaena & ТНАСН 2016а: 71 & no comment \\
\hline hongdaoae & Amphidromus & THACH 2017a: 40 & $\mathrm{LC}$ \\
\hline huberi & Alycaeus & THACH 2018a: 19 & MC, damaged subadult \\
\hline huberi & Amphidromus & ТНACH 2014: 39 & probably valid, subadult \\
\hline huberi & Ariophanta & ТНАСН 2018a: 41 & LC, juvenile of Pollicaria rochebruni \\
\hline huberi & Barnaia & THACH 2017a: 18 & valid \\
\hline huberi & Bouchetcamaena & ТНАСН 2018a: 65 & $\mathrm{LC}$ \\
\hline huberi & Bradybaena & ТНАСН 2018a: 73 & no comment \\
\hline huberi & Camaena & THACH 2017a: 51 & juveniles or subadults \\
\hline huberi & Chloritis & THACH 2016a: 72 & no comment \\
\hline huberi & Cyathopoma & ТНАСН 2018a: 15 & no comment \\
\hline huberi & Cyclophorus & ТНАСН 2016а: 35 & see under Cyclophorus \\
\hline huberi & Cyclotopsis & THACH 2018a: 24 & LC \\
\hline huberi & Cyclotus & ТНАСН 2018a: 16 & key trait is teratological \\
\hline huberi & Discartemon & ТНАСН 2017a: 30 & LC \\
\hline huberi & Euplecta & ТНАСН 2018a: 41 & MC \\
\hline huberi & Ganesella & ТНАСН 2018а: 69 & no comment \\
\hline huberi & Glessula & ТНАСН 2018a: 37 & no comment \\
\hline huberi & Helminthoglypta & ТНАCH 2017a: 54 & see under Hemiplecta lanxangnica \\
\hline
\end{tabular}




\begin{tabular}{|c|c|c|c|}
\hline Species and subspecies & $\begin{array}{l}\text { Original generic } \\
\text { placement }\end{array}$ & References & Remarks \\
\hline huberi & Hemiphaedusa & ТНACH 2016a: 58 & subspecies of Oospira naggsi \\
\hline huberi & Hemiplecta & THACH 2017a: 33 & $\mathrm{MC}$ \\
\hline huberi & Indoartemon & ТHACH 2018a: 39 & $\mathrm{LC}$ \\
\hline huberi & Kalidos & ТНАСН 2018a: 43 & LC \\
\hline huberi & Lamprellia & ТHACH 2018a: 70 & no comment \\
\hline huberi & Megalacron & ТHACH 2017a: 53 & $\mathrm{NC}$ \\
\hline huberi & Microstele & THACH 2018a: 37 & NC \\
\hline huberi & Mirus & ТHACH 2018a: 37 & LC \\
\hline huberi & Mussonena & ТНACH 2018a: 70 & NC \\
\hline huberi & Mysticarion & ТHACH 2016a: 61 & NC \\
\hline huberi & Neniauchenia & THACH 2016a: 58 & valid \\
\hline huberi & Oophana & ТНАСН 2018a: 39 & valid \\
\hline huberi & Oospira & THACH 2016a: 57 & valid \\
\hline huberi & Pallgergelyia & THACH 2017a: 32 & valid \\
\hline huberi & Pearsonia & ТНАСН 2016а: 36 & $\mathrm{NC}$ \\
\hline huberi & Pollicaria & ТНACH 2018a: 20 & LC \\
\hline huberi & Prosopeas & THACH 2018a: 38 & LC \\
\hline huberi & Pseudobuliminus & THACH 2017a: 55 & LC \\
\hline huberi & Pseudopartula & ТНАСН 2016а: 74 & valid \\
\hline huberi & Pterocyclos & ТНACH 2015b: 59 & no comment \\
\hline huberi & Rhiostoma & ТHACH 2018a: 17 & no comment \\
\hline huberi & Satsuma & THACH 2018a: 71 & no comment \\
\hline huberi & Streptartemon & ТНАСН 2016а: 60 & $\mathrm{NC}$ \\
\hline huberi & Tortulosa & THACH 2018a: 21 & MC \\
\hline huberi & Trochomorpha & ТНACH 2018a: 45 & valid \\
\hline huberi & Tropidophora & ТНАСН 2018a: 24 & subadult shell \\
\hline huberi & Vargapupa & ТНАCH 2018a: 22 & MC \\
\hline huberi vinhensis & Camaena & ТНАСН 2018a: 67 & juveniles \\
\hline hueae & Amphidromus & Thach et Huber in THACH 2016a: 66 & $\mathrm{LC}$ \\
\hline hueae & Euplecta & Thach et Huber in THACH 2018a: 42 & LC \\
\hline huynhanhi & Amphidromus & ТНАСH 2019f: 11 & no comment \\
\hline huynhi & Amphidromus & THACH 2019c: 104 & no comment \\
\hline jeffabbasorum & Amphidromus & THACH 2016c: 3 & no comment \\
\hline johnabbasi & Amphidromus & ТНАCH 2017b: 35 & $\mathrm{LC}$ \\
\hline johnstanisici & Amphidromus & Thach et Huber in THACH 2017a: 41 & no comment \\
\hline juniorabbasi & Amphidromus & THACH 2018a: 55 & $\mathrm{LC}$ \\
\hline keppensdhondtorum & Amphidromus & ТНАCH 2018b: 31 & no comment \\
\hline khamducensis & Camaena & Thach et Huber in THACH 2018a: 67 & $\mathrm{NC}$ \\
\hline khammouanensis & Amphidromus & Thach et Huber in THACH 2017a: 41 & valid, two broken, half shells \\
\hline khongensis & Cyclophorus & Thach et Huber in THACH 2017a: 14 & See under Cyclophorus \\
\hline klausgrohi & Chloritis & Thach et Huber in THACH 2017a: 52 & valid \\
\hline koenigi & Amphidromus & Thach et Huber in THACH 2018a: 56 & valid, subadult shells \\
\hline koonpoi & Amphidromus & Thach et Huber in THACH 2018a: 56 & LC \\
\hline lacthuyensis & Camaena & THACH 2016a: 71 & LC \\
\hline laevus lakorensis & Amphidromus & THACH 2019e: 232 & no comment \\
\hline laii & Amphidromus & THACH 2019b: 37 & no comment \\
\hline lamdongensis & Amphidromus & Thach et Huber in THACH 2016a: 67 & $\mathrm{LC}$ \\
\hline ledaoae & Amphidromus & ТНАCH 2016а: 67 & no comment \\
\hline ledaoae anhi & Amphidromus & ТНАСН 2018а: 56 & LC, subadult shells \\
\hline
\end{tabular}




\begin{tabular}{|c|c|c|c|}
\hline Species and subspecies & $\begin{array}{l}\text { Original generic } \\
\text { placement }\end{array}$ & References & Remarks \\
\hline leeana & Camaena & THACH 2017a: 52 & LC \\
\hline liei & Amphidromus & THACH 2017b: 36 & no comment \\
\hline liei & Hemiplecta & ТНАСН 2018a: 43 & no comment \\
\hline liei joshuathami & Amphidromus & THACH 2018b: 35 & no comment \\
\hline louiseae & Obba & THACH 2016g: 3 & no comment \\
\hline lucsegersi & Amphidromus & THACH \& ABBAS 2017a: 52 & $\mathrm{LC}$ \\
\hline maestratii & Pseudobuliminus & THACH 2017a: 55 & see under Giardia \\
\hline mariae & Amphidromus & Thach et Huber in THACH 2017a: 42 & valid \\
\hline marieabbasae & Amphidromus & ТНACH 2017a: 42 & MC, juvenile shells \\
\hline mariesandersae & Amphidromus & Thach et Huber in THACH 2017a: 42 & valid, juvenile shells \\
\hline melanostoma janetabbasae & Leptopoma & THACH 2018c: 264 & no comment \\
\hline monsecourorum & Amphidromus & Thach et Huber in THACH 2017a: 43 & no comment \\
\hline montesdeocai & Amphidromus & Thach et Huber in THACH 2017a: 43 & MC \\
\hline naggsi & Amphidromus & THACH \& HUBER 2014: 35 & MC \\
\hline ngai & Amphidromus & THACH 2019h: 33 & no comment \\
\hline ngheanensis & Cyclophorus & Thach et Huber in THACH 2018a: 15 & see under Cyclophorus \\
\hline ngocanhi & Amphidromus & ТНАСН 2017a: 43 & MC \\
\hline ngocngai & Amphidromus & ТНАСН 2017a: 44 & MC \\
\hline ngocngai & Rhiostoma & Thach et Huber in THACH 2018a: 17 & no comment \\
\hline nicoi & Amphidromus & THACH 2017c: 298 & no comment \\
\hline nicoi & Pollicaria & THACH 2018a: 21 & MC \\
\hline ninhbinhensis & Camaena & ТНACH 2016a: 72 & valid \\
\hline ninhbinhensis & Rhiostoma & Thach et Huber in THACH 2018a: 17 & LC \\
\hline ninhhoaensis & Thachia & Huber in THACH 2018a: 40 & valid \\
\hline noriokowasoei & Amphidromus & THACH \& HUBER 2017: 123 & LC \\
\hline obesa & Pseudobuliminus & Thach et Huber in ТHACH 2018a: 73 & see under Giardia \\
\hline onae & Camaena & ТНАСН 2016f: 17 & valid \\
\hline ovoideus & Pseudobuliminus & Thach et Huber in THACH 2018a: 74 & see under Giardia \\
\hline owengriffithsi & Obeliscus & Thach et Huber in THACH 2017a: 30 & LC \\
\hline pallgergelyi & Amphidromus & Thach et Huber in THACH 2018a: 58 & LC \\
\hline pallgergelyi & Discartemon & ТНАСН 2017a: 31 & MC \\
\hline pamabbasae & Amphidromus & THACH 2017f: 34 & LC \\
\hline patamakanthini & Amphidromus & Thach et Huber in THACH 2018a: 59 & LC \\
\hline pengzhuoani & Amphidromus & ТНАСН 2018b: 34 & LC \\
\hline perversus siglerae & Amphidromus & ТНАCH 2018a: 59 & no comment \\
\hline petuchi & Amphidromus & ТНACH 2018a: 60 & $\mathrm{LC}$ \\
\hline phamanhi & Amphidromus & ТНАСН 2016а: 68 & valid \\
\hline philippeboucheti & Amphidromus & THACH 2019c: 103 & no comment \\
\hline phuonglinhae & Amphidromus & THACH 2017a: 45 & LC \\
\hline phuonglinhae vinhensis & Amphidromus & Thach et Huber in THACH 2018a: 60 & LC, juveniles, weathered \\
\hline renkeri & Amphidromus & ТНACH 2018b: 33 & $\mathrm{LC}$ \\
\hline reuselaarsi & Amphidromus & ТНАCH 2018a: 61 & no comment \\
\hline richgoldbergi & Amphidromus & Thach et Huber in THACH 2017a: 45 & LC \\
\hline salzmanni & Amphidromus & Thach et Huber in THACH 2017a: 45 & LC \\
\hline schileykoi & Amphidromus & THACH 2016a: 68 & MC \\
\hline schileykoi & Pterocyclos & Thach et Huber in THACH 2017a: 17 & valid \\
\hline schileykoi & Tortulosa & Thach et Huber in THACH 2018a: 22 & MC \\
\hline semicinereus & Amphidromus & ТHACH 2018a: 62 & LC \\
\hline setzeri & Amphidromus & ТHACH 2015a: 56 & LC \\
\hline
\end{tabular}




\begin{tabular}{|c|c|c|c|}
\hline Species and subspecies & $\begin{array}{l}\text { Original generic } \\
\text { placement }\end{array}$ & References & Remarks \\
\hline setzeri & Bertia & THACH 2015c: 240 & valid \\
\hline severnsi & Amphidromus & THACH 2017a: 46 & LC \\
\hline severnsi anhi & Amphidromus & THACH 2018a: 62 & LC \\
\hline siglerae & Rhynchotrochus & ТНАСН 2018a: 72 & no comment \\
\hline simonei & Diastole & Thach et Huber in THACH 2017a: 34 & LC \\
\hline simonei & Quantula & Thach et Huber in THACH 2018a: 44 & no comment \\
\hline siongkiati & Amphidromus & THACH 2019d: 17 & no comment \\
\hline sriabbasae & Amphidromus & ТНАСН 2017a: 47 & no comment \\
\hline sowyani & Amphidromus & THACH 2019h: 35 & no comment \\
\hline stevehubrechti & Amphidromus & ТНАСН \& ABBAS 2017b: 119 & LC \\
\hline stevenabbasorum & Cyclophorus & THACH 2016b: 118 & see under Cyclophorus \\
\hline steveni & Amphidromus & THACH 2017b: 36 & LC, immature shells \\
\hline stungtrengensis & Amphidromus & Thach et Huber in THACH 2018a: 63 & LC, single subadult shell \\
\hline stungtrengensis & Cyclophorus & Thach et Huber in THACH 2018a: 16 & see under Cyclophorus \\
\hline szekeresi & Discartemon & Thach et Huber in THACH 2018a: 38 & LC \\
\hline szekeresi & Liparophaedusa & ТНАСН 2017a: 29 & valid \\
\hline tedbaeri & Amphidromus & ТНACH 2017b: 37 & LC, immature shells \\
\hline thachi & Bouchetcamaena & Huber in ТНАСН 2018a: 65 & no comment \\
\hline thachi & Chloritis & Huber in ТНАСН 2018a: 69 & no comment \\
\hline thachi & Ganesella & Huber in ТНACH 2018a: 70 & no comment \\
\hline thachi & Pearsonia & Huber in ТHACH 2017a: 16 & $\mathrm{LC}$ \\
\hline thachi & Perrottetia & Huber in ТНАСН 2018a: 40 & see comment under $P$. thachi \\
\hline thachi & Pseudobuliminus & Huber in THACH 2018a: 74 & see under Giardia \\
\hline thachi & Pterocyclos & Huber in ТНАСН 2017a: 17 & no comment \\
\hline thachi & Rhiostoma & Huber in ТНАСН 2018a: 17 & no comment \\
\hline thachi & Satsuma & Huber in ТНАСН 2018a: 71 & no comment \\
\hline thachi krisi & Amphidromus & ТНАСН 2018a: 63 & valid \\
\hline thachi laosianus & Chloritis & Huber in THACH 2018a: 69 & no comment \\
\hline thakhekensis & Amphidromus & Thach et Huber in THACH 2017a: 48 & LC \\
\hline thakhekensis & Cyclophorus & Thach et Huber in THACH 2018a: 16 & See under Cyclophorus \\
\hline thanhhoaensis & Amphidromus & Thach et Huber in THACH 2016a: 69 & valid \\
\hline thanhhoaensis & Camaena & ТНАСH 2016a: 72 & valid \\
\hline thuthaoae & Oophana & ТНАСН 2017a: 32 & valid \\
\hline trianensis & Amphidromus & Thach et Huber in THACH 2018a: 64 & no comment \\
\hline trochus janetabbasae & Asperitas & ТНАСH 2018a: 44 & no comment \\
\hline truongkhoai & Amphidromus & ТHACH 2018a: 64 & LC \\
\hline tuongvyae & Pseudobuliminus & THACH 2017a: 56 & LC \\
\hline vietnamensis & Amphidromus & Thach et Huber in THACH 2017a: 48 & MC \\
\hline vilvensi & Pearsonia & Thach et Huber in THACH 2017a: 16 & valid \\
\hline vinhensis & Trochomorpha & ТНACH 2018a: 45 & LC \\
\hline yangbayensis & Amphidromus & Thach et Huber in THACH 2016a: 70 & LC, weathered juveniles \\
\hline yauyeejiae & Amphidromus & Thach et Abbas in THACH 2017a: 49 & no comment \\
\hline yenlinhae & Amphidromus & Thach et Huber in THACH 2017a: 49 & $\mathrm{LC}$ \\
\hline
\end{tabular}

